\title{
O PAPEL DOS NEUTRÓFILOS E DOS RECEPTORES TLR-2 E TLR-4 NA CROMOBLASTOMICOSE EXPERIMENTAL EM INFECÇÃO POR FONSECAEA PEDROSOI
}

Tese apresentada ao programa de Pós-graduação em Imunologia do Instituto de Ciências Biomédicas da Universidade de São Paulo para obtenção do Título de Doutor em Ciências.

Área de concentração: Imunologia

Orientador: Prof. Dr. Sandro Rogério de Almeida Versão Original

São Paulo 


\section{O PAPEL DOS NEUTRÓFILOS E DOS RECEPTORES TLR-2 E TLR-4 NA CROMOBLASTOMICOSE EXPERIMENTAL EM INFECÇÃO POR FONSECAEA PEDROSOI}

Tese apresentada ao programa de Pós-graduação em Imunologia do Instituto de Ciências Biomédicas da Universidade de São Paulo para obtenção do Título de Doutor em Ciências.

Área de concentração: Imunologia

Orientador: Prof. Dr. Sandro Rogério de Almeida

Versão Original

São Paulo 
Candidato(a): Leandro Carvalho Dantas Breda

Titulo da Dissertação/Tese: O PAPEL DOS NEUTRÓFILOS E DOS RECEPTORES TLR-2 E TLR-4 NA CROMOBLASTOMICOSE EXPERIMENTAL EM INFECÇÃO POR FONSECAEA PEDROSOI

Orientador: Prof. Dr. Sandro Rogério de Almeida

A Comissão Julgadora dos trabalhos de Defesa da Dissertação de Mestrado/Tese de Doutorado, em sessão publica realizada a ............................., considerou o(a) candidato(a):

\section{( ) Aprovado(a) ( ) Reprovado(a)}

Examinador(a):

Assinatura:

Nome:

Instituição:

Examinador(a):

Assinatura:

Nome:

Instituição:

Examinador(a):

Assinatura:

Nome:

Instituição:

Presidente:

Assinatura:

Nome:

Instituição: 


\section{CerTificado}

Certificamos que o protocolo registrado sob $n^{\circ} \mathbf{7 4}$ nas fls. 20 do livro 03 para uso de animais em experimentaçäo, sob a responsabilidade do $\operatorname{Prof(a)} \operatorname{Dr}(a)$ Sandro Rogério de Almeida, Coordenador (a) da Linha de pesquisa "O Papel dos Neutrófilos e dos Receptores TLR 2 e TLR 4 na Cromoblastomicose Experimental em Infecção por Fonsecae pedrosoi" do qual participam o(s) aluno(s) Leandro Carvalho Dantas Breda, está de acordo com os Princípios Éticos de Experimentação Animal adotado pela Sociedade Brasileira de Ciência de Animais de Laboratório (SBCAL) e foi aprovado pela COMISSÃO DE ÉTICA NO USO DE ANIMAIS (CEUA) em 18.08.2014, com validade de 4 anos.

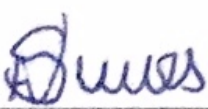

Prof. Dr. ANDERSON DE SÁ NUNES Vice-Coordenador-CEUA-ICB/USP
São Paulo, 19 de agosto de 2014.

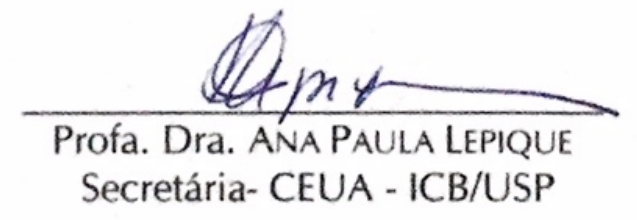




\section{c) \\ ICBUSP}

Cidade Universitária "Armando de Salles Oliveira", Butantã, São Paulo, SP · Av. Professor Lineu Prestes, 2415 - ICB III - 05508000 Comissão de Ética no Uso de Animais - Telefone (11) 3091-7733 - e-mail: cep@icb.usp.br

Of.CEUA.085.2018

São Paulo, 02 de agosto de 2018.

Prezado(a) Professor(a),

Informo que o projeto intitulado " O Papel dos Neutrófilos e dos Receptores TLR 2 e TLR 4 na Cromoblastomicose Experimental em Infecção por Fonsecae pedroso ", registrado sob o protocolo no $\mathbf{0 7 4 / 2 0 1 4}$ e aprovado em 18/08/2014, que envolve a produção, manutenção e/ou utilização de animais pertencentes ao filo Chordata, subfilo Vertebrata (exceto o homem), para fins de pesquisa científica, foi prorrogado até 18/08/2022.

Diante desta prorrogação e da declaração de que não houve alteração da metodologia e das técnicas descritas na licença inicial para o uso de animais, autorizo a inclusão das espécies e quantidades descritas abaixo para continuidade ao referido projeto:

\begin{tabular}{|l|l|l|l|l|}
\hline Espécie & Linhagem & Sexo & Idade/Peso & Quantidade por ano \\
\hline Mus musculus & C57bl/6 & Macho & 8-12 semanas & 102 \\
\hline Mus musculus & $\begin{array}{l}\text { C57bl/6 KO p/ } \\
\text { TLR 2 }\end{array}$ & Macho & 8-12 semanas & 54 \\
\hline Mus musculus & $\begin{array}{l}\text { C57bl/6 KO p/ } \\
\text { TLR 4 }\end{array}$ & Macho & 8-12 semanas & 54 \\
\hline
\end{tabular}

Reitero que havendo alteração de metodologia e inserção de novos alunos ao projeto de pesquisa vinculado à referida licença a CEUA-ICB deverá ser informada.

Cordialmente,

Luciane Valéria sita

Profa. Dra. Luciane Valéria Sita

Coordenadora CEUA-ICB/USP

Prof.(a) Dr.(a) Sandro Rogério de Almeida

Departamento de Imunologia

Instituto de Ciências Biomédicas - USP 
À minha família, especialmente à minha esposa por todo o suporte e contribuição científica para o desenvolvimento desta Tese. 
"Um país que não investe em educação, investe em prisão" Autor desconhecido 


\section{AGRADECIMENTOS}

Primeiramente gostaria de agradecer a Deus, que sempre me guiou e iluminou minha vida e meu caminho. Agradeço a ele pela família maravilhosa a qual pertenço e por todas as bênçãos derramadas em minha vida. Agradeço aos meus pais, pela paciência, dedicação e empenho em minha criação. Por me ensinarem o que é o certo e o errado, por me ensinarem o valor das coisas e não o seu preço, por me ensinarem que a educação é capaz de mudar o mundo. Agradeço à minha mãe por todas as lições tomadas antes de cada prova realizada. Agradeço a minha tia "Regi", por sempre se orgulhar da minha profissão e por estar presente me apoiando em minha defesa de mestrado. Tenho certeza que você estará presente novamente em minha defesa de doutorado. Agradeço à família que Deus me deu em 2016. Meu sogro "Zé" e minha sogra "Lourdinha" por estarem sempre presentes e interessados em entender um pouco mais do dia a dia de um pesquisador. Agradeço à minha esposa Cristiane, por todo seu apoio durante esses mais de 7 anos de pesquisa. Por não me deixar desistir, por acreditar mais em mim do que eu mesmo e por sempre me incentivar a querer mais. Agradeço sua ajuda científica neste trabalho. Por todas as discussões, desenhos experimentais e horas disponibilizadas para me ajudar em meus experimentos. Agradeço por você me mostrar o quão "flexível" nós podemos ser, tudo depende do nosso esforço e estudo. Você sabe o quanto admiro sua capacidade em se tornar conhecedora dos mais diversos assuntos. E por fim, agradeço sua correção e sugestões nesta Tese.

Gostaria de agradecer também ao Prof. Dr. Sandro Rogério de Almeida pela amizade e por ter aberto a porta de seu laboratório para que eu pudesse desenvolver esta Tese de Doutorado. Por confiar e acreditar em meu trabalho e por sempre me incentivar a buscar o melhor para minha carreira.

À Professora Karen Spadari Ferreira, pelas sugestões e colaborações neste trabalho. Sem sua colaboração com os animais este trabalho não estaria completo. Obrigado também pela sua amizade.

Agradeço ao Professor Niels Olsen Saraiva Câmara, por todo o apoio e amizade, e por estar sempre disposto a me ajudar. Obrigado também por suas sugestões 
e materiais cedidos para a realização desse trabalho. Sua colaboração foi crucial.

Agradeço os atuais e ex-membros do Laboratório de Micologia pela ajuda e amizade.

Ao Lucas Gonçalves Ferreira pela amizade pela ajuda na escrita inicial deste projeto e por me ensinar a trabalhar com $F$. pedrosoi.

Ao Gilberto Kaihami, José Roberto de Almeida, Grasielle Jannuzzi e Suellen dos Santos por me acolherem assim que cheguei ao Laboratório de Micologia, e também por toda ajuda científica e amizade dentro e fora do laboratório.

Agradeço à Isabela de Godoy e Larissa Neves pela amizade e discussões sobre Cromoblastomicose.

Agradeço à Renata Albuquerque pela amizade, ajuda nos mais diversos experimentos de citometria e, principalmente, por todo o seu tempo e esforço colocado para organizar e melhorar o Laboratório de Micologia.

Agradeço ao Maurício Santos (Mau), por nos salvar no conserto de equipamentos e computadores e pela sua amizade.

Agradeço à Eni, por toda a ajuda com a pós-graduação, nunca me deixando esquecer os prazos e documentos necessários. Obrigado pela sua amizade.

Agradeço ao João e ao Mario, por sempre serem solícitos e estarem dispostos a me ajudar.

Agradeço à Profa. Lourdes Isaac, por tudo que me ensinou durante meu mestrado, me iniciando na carreira científica. Obrigado pela ajuda e sugestões durante minha qualificação de doutorado e pela sua amizade.

Agradeço também à Simone e ao Toni, pela amizade num momento crucial e tão desafiador de nossas vidas, o ano de 2017 foi muito mais prazeroso e divertido ao lado de vocês. Amizade para a vida toda.

I am very thankful to Dr. Nades Palaniyar for having me at his Lab and for all the knowledge shared and patient with me. You were always kind and helpful to me I also thank all the lab members, Meraj, Lynn, Christina, Frank, Hussein, Zubair, Raquel, Pascal, Dhia, Louiza, Johann, Jerry, Harvard, Jacky and Lidgy for the suggestions during the lab meeting and the pleasant and fun moments we have spent together. My special thanks to Lynn for her patient and all the good moments we have spent together. Thanks to you Toronto looked like a little more home to me, even with $-30^{\circ}$ degrees Celsius. 
Por fim, agradeço a todos que contribuíram, direta ou indiretamente, para a realização desse trabalho.

\section{ENTIDADES DE FOMENTO}

Este trabalho foi desenvolvido com o apoio da Fundação de Amparo à Pesquisa do Estado de São Paulo (FAPESP, Processos 2014/11146-9, 2016/14849-6, 2012/18598-7 e 2016/04729-3), do Conselho Nacional de Desenvolvimento Científico e Tecnológico (CNPq) e da Coordenação de Aperfeiçoamento de Pessoal de Nível Superior (CAPES), código de financiamento 001. 


\section{RESUMO:}

Breda, LCD. O papel dos neutrófilos e dos receptores TLR-2 e TLR-4 na Cromoblastomicose experimental em infecção por F. pedrosoi. [Tese (Doutorado em Imunologia)]. São Paulo: Instituto de Ciências Biomédicas, Universidade de São Paulo, 2019.

A cromoblastomicose é uma micose subcutânea crônica e progressiva causada principalmente pelo fungo Fonsecaea pedrosoi. As infecções estabelecidas podem desenvolver lesões crostosas e exsudativas com formação de granulomas, compostos principalmente por macrófagos e neutrófilos. O F. pedrosoi é um fungo dimórfico e pode ser encontrado na forma de micélios e conídios (fase saprófita) e na forma de esclerótica (fase infecciosa). A forma esclerótica é altamente resistente aos mecanismos imunológicos do hospedeiro permitindo, portanto, a instalação e progressão da doença. Poucos são os trabalhos que observaram o papel dos neutrófilos - importante célula no combate a infecções fúngicas - na eliminação do F. pedrosoi. Neste presente trabalho nós verificamos a importância dos neutrófilos murinos na eliminação in vitro das hifas e conídios de $F$. pedrosoi.

Palavras-chave: Neutrófilo, Cromoblastomicose, F. pedrosoi, MDSCs 


\begin{abstract}
Breda, LCD. The role of neutrophils and Toll Like Receptors 2 and 4 in experimental Chromoblastomycosis by F. pedrosoi. [Tese (Doutorado em Imunologia)]. São Paulo: Instituto de Ciências Biomédicas, Universidade de São Paulo, 2019.

Chromoblastomycosis is a chronic and progressive subcutaneous mycosis caused mainly by the fungus Fonsecaea pedrosoi. The infection is characterized by erythematous papules and the histological sections composed of an external layer of fibrous tissue and an internal layer of thick granulomatous inflammatory tissue containing mainly macrophages and Neutrophils. F. pedrosoi is a dimorphic fungus and can be found in mycelium and conidial forms (saprophyte phase) or sclerotic bodies (infection phase) - characterized by spherical bodies with thickness and pigmented cell wall. Currently, little is known about neutrophils functions in chromoblastomycosis. Several groups have been studying the role of the innate and adaptive immune system in infection by $F$. pedrosoi, however few studies have been focusing on the neutrophils role in this infection. In this study we verified the importance of murine neutrophils in F. pedrosoi conidia and hyphae killing.
\end{abstract}

Keywords: Neutrophil, Chromoblastomycosis, F. pedrosoi, MDSCs 


\section{LISTA DE FIGURAS}

Figura 1 Mapa epidemiológico da Cromoblastomicose:...............................22

Figura 2 Lesões típicas observadas na Cromoblastomicose:. ……..................23

Figura 3 Achados histopatológicos na Cromoblastomicose:..........................23

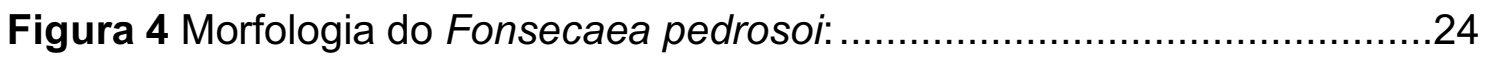

Figura 5 Composição estrutural da parede celular de fungos:.......................25

Figura 6 Sequência de eventos necessários para o recrutamento de neutrófilos:.

Figura 7 Processo de fagocitose de organismos estranhos por neutrófilos: ....37

Figura 8 Formação e localização da fagócito oxidase:. ...................................38

Figura 9 Etapas da formação de espécies reativas de oxigênio (ROS) e de

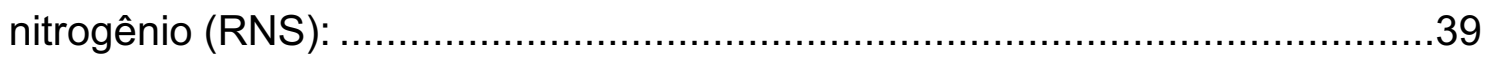

Figura 10 Processo de degranulação de neutrófilo: .......................................40

Figura 11 Liberação de NETs por neutrófilos humanos: ................................42

Figura 12 Purificação de neutrófilos provenientes da medula óssea de camundongos:

Erro! Indicador não definido.

Figura 13 Capacidade fungicida dos neutrófilos e a importância do TLR-2 e TLR4 na eliminação dos conídios e hifas de F. pedrosoi:Erro! Indicador não definido.

Figura 14 A fagocitose é um importante processo na eliminação dos conídios, mas não de hifas, de F. pedrosoi:

Erro! Indicador não definido.

Figura 15 Os receptores TLR-2 e TLR-4 são importantes para a fagocitose de conídios de F. pedrosoi: Erro! Indicador não definido.

Figura 16 Produção de ROS em neutrófilos murinos é estimulada por conídios e inibida por hifas de F. pedrosoi:

Erro! Indicador não definido.

Figura 17 TLR-2 e TLR-4 estão envolvidos na produção de ROS em neutrófilos murinos frente à infecção por conídios, mas não por hifas de F. pedrosoi: . Erro! Indicador não definido.

Figura 18 A produção de ROS é importante na eliminação de conídios, mas não de hifas de F. pedrosoi: Erro! Indicador não definido.

Figura 19 Hifas, mas não conídios de F. pedrosoi, estimulam liberação de NETs: 
Figura 20 TLR-2 e TLR-4 não participam da liberação de NETs sobre as hifas de F. pedrosoi: Erro! Indicador não definido.

Figura 21 Função fungicida das NETs sobre as hifas de F. pedrosoi: ......... Erro! Indicador não definido.

Figura 22 Receptores TLR-2 e TLR-4 são importantes na migração de neutrófilos em infecções por conídios e hifas de F. pedrosoi:Erro! Indicador não definido.

Figura 23 Aumento da população de neutrófilos no baço e fígado de animais TLR-2KO e TLR-4KO infectados com conídios de F. pedrosoi:.Erro! Indicador não definido.

Figura 24 Receptores TLR-2 e TLR-4 são importantes no controle da infecção in vivo: Erro! Indicador não definido.

Figura 25 Neutropenia causada pela administração de anti-Gr1: Erro! Indicador não definido.

Figura 26 Neutropenia causada pela administração de anti-Gr1 durante infecção por conídios de F. pedrosoi: Erro! Indicador não definido.

Figura 27 Imunofenotipagem das células do baço e fígado de animais C57BI6 WT e neutropênicos após 24 e 48 hrs de infecção por conídios de F. pedrosoi:

Erro! Indicador não definido.

Figura 28 Citocinas dosadas no sobrenadante de baço de animais C57BI6 WT e neutropênicos após 24 e 48 hrs de infecção por conídios de F. pedrosoi:Erro! Indicador não definido.

Figura 29 Citocinas dosadas no sobrenadante de fígado de animais C57BI6 WT e neutropênicos após 24 e 48 hrs de infecção por conídios de F. pedrosoi:Erro! Indicador não definido.

Figura 30 Análise da carga fúngica no baço e fígados dos animais após 24 e 48 hrs de infecção por F. pedrosoi. Erro! Indicador não definido. Figura 31 Imunofenotipagem das células do baço e fígado de animais C57BI6 WT e neutropênicos após 14 dias de infecção por conídios de F. pedrosoi:Erro! Indicador não definido.

Figura 32 Citocinas dosadas no sobrenadante de baço e fígado de animais C57BI6 WT e neutropênicos após 14 dias de infecção por conídios de $F$. pedrosoi: Erro! Indicador não definido. 
Figura 33 Análise da carga fúngica no baço e fígados dos animais após 14 dias de infecção por $F$. pedrosoi Erro! Indicador não definido. Figura 34 Análise da produção de anticorpos específicos contra conídios de $F$. pedrosoi após 14 dias de infecção: Erro! Indicador não definido. Figura 35 Análise da importância dos neutrófilos na ativação de células $T$ em animais infectados com $F$. pedrosoi. Erro! Indicador não definido.

\section{LISTA DE TABELAS}

Tabela 1: Ligantes dos receptores TLR-2 e TLR-4 30

Tabela 2: Composição dos grânulos presentes nos neutrófilos

Tabela 3: Marcadores de superfície e ensaios funcionais dos neutrófilos e MDSCs

Tabela 4: Marcadores utilizados para a Imunofenotipagem das células obtidas do baço e fígado de animais infectados. 56

Tabela 5: Quantidade de anti-Gr1 necessária para a depleção de neutrófilos circulantes em animais C57BI/6 WT Erro! Indicador não definido. 


\title{
LISTA DE ABREVIATURAS E SIGLAS
}

\begin{abstract}
$\Delta \mathrm{NE}:$ Animais tratados com anti-Gr1
\end{abstract}
APCs: Células apresentadoras de antígenos

BSA: Albumina de soro bovino (do inglês Bovine Serum Albumin)

CFU: Unidades formadoras de colônias (do inglês Colony-Forming Unit)

$\mathrm{CIO}^{-}$: Hipoclorito

CLR: Receptores de Lectina do tipo C (do inglês C-type lectin receptors)

DAPI: 4',6-diamidino-2-phenylindole

DCs: Células dendríticas (do inglês Dendritic Cells)

DPI: Diphenyleneiodonium

ecROS: ROS extracelular

GAG: Galactosaminogalactan

(G)-MDSCs: do inglês Granulocytic Myeloid-Derived Suppressor Cell

HCIO: Ácido hipocloroso

HK: Morto pelo calor (do inglês Heat Killed)

iNOS: Óxido nítrico sintase induzida

i.p.: Intraperitoneal

KO: Knockout

LPS: Lipopolissacarídeo

MHC: Complexo maior de histocompatibilidade (do inglês Major

Histocompatibility Complex)

MDSC: do inglês Myeloid-Derived Suppressor Cell 
(Mo)-MDSCs: do inglês Monocitic Myeloid-Derived Suppressor Cell

MOI: Multiplicity of infection

MPO: Mieloperoxidase

NETs: do inglês Neutrophil Extracelluar Traps

NK: do inglês Natural Killer

NLR: Receptores semelhantes ao NOD (do inglês NOD like Receptors)

NO: óxido nítrico

NOX: NADPH Oxidase

nphROS: ROS não fagocítico

PAD-4: Peptidylarginine deiminases 4 (PAD 4)

PAMPs: Padrões Moleculares Associados aos Patógenos (do Inglês PathogenAssociated Molecular Pattern)

PBS: Solução salina tamponada estéril

PBS-T: PBS contendo tween 20

PFA: Paraformaldeído

phROS: ROS fagocítico

PMA: Phorbol Myristate Acetate

PMN-MDSCs: do inglês polymorphonuclear-MDSCs

R10: RPMI com 10\% SFB

R10-Low: RPMI com 10\% de soro IgG low

R20: RPMI com 20\% SFB

PRRs: Receptores de Reconhecimento Padrão (do inglês Pattern Recognition Receptors)

ROS: Espécies reativas de oxigênio (do inglês Reactive Oxygen Species)

SDS-PAGE: Eletroforese em gel de poliacrilamida na presença de docecil

sulfato de sódio

SC: Sistema complemento

SFB: Soro fetal bovino

SIA: Sistema imune adaptativo

SIl: Sistema imune inato

SOD: Superóxido dismutase

TANs: Neutrófilos associados aos tumores

TLR: Receptores semelhantes ao Toll (do inglês Toll-like Receptors)

WB: Western Blot 
WT: selvage (do inglês Wild Type)

\section{LISTA DE SUMÁRIO}

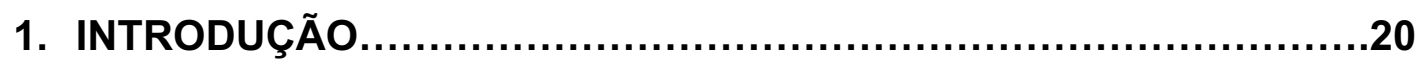

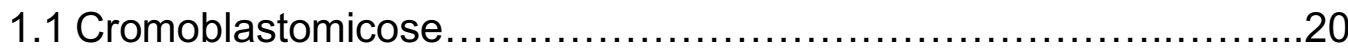

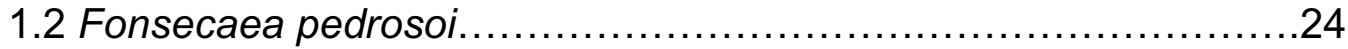

1.2.1 Diferenças morfológicas e estruturais entre as diferentes

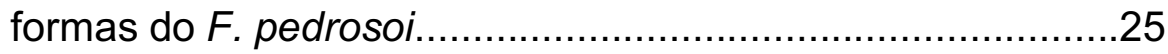

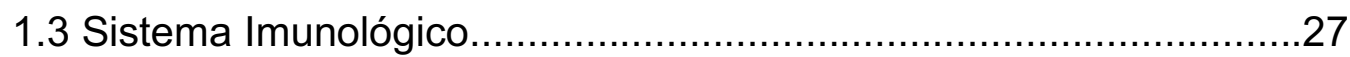

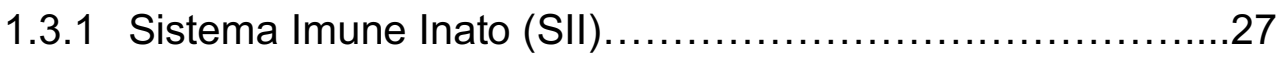

1.3.1.1 Receptores de reconhecimento padrão: Toll-Like

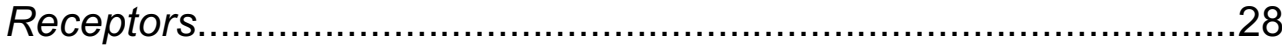

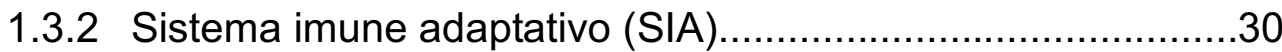

1.4 Resposta imunológica da Cromoblastomicose................................31

1.4.1 Resposta imune adaptativa....................................

1.4.2 Resposta imune inata...........................................

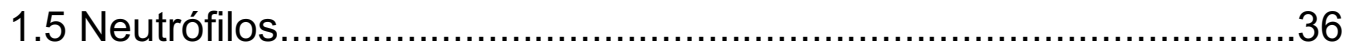

1.5.1 Principais mecanismos efetores dos neutrófilos....................36

1.5.1.1 Fagocitose ..............................................

1.5.1.2 Liberação de grânulos....................................40

1.5.1.3 Neutrophil Extracellular Traps-NETs....................42

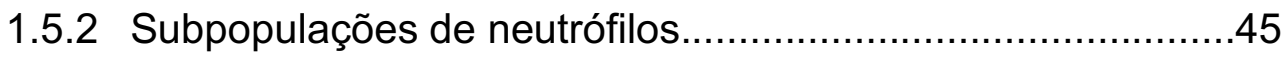

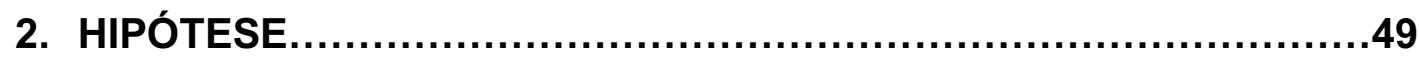

3. OBJETIVOS

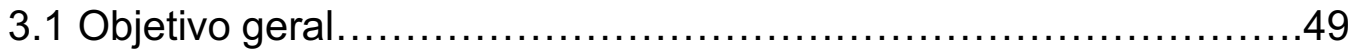


3.2 Objetivos específicos 49

4. MATERIAIS E MÉTODOS...............................................................5

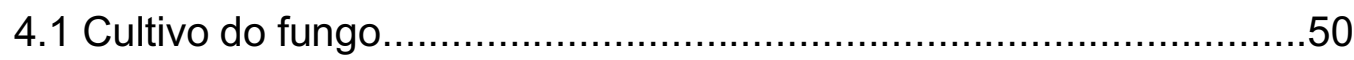

4.1.1 Obtenção de inóculo enriquecido de conídios ou hifas.............50

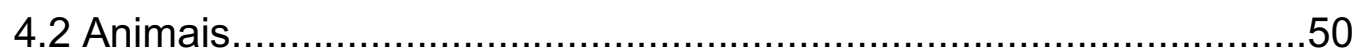

4.3 Obtenção de neutrófilos murinos da medula óssea............................50

4.4 Ensaio da atividade fungicida dos neutrófilos..................................52

4.4.1 Morte por fagocitose ou liberação das NETs.........................52

4.5 Avaliação do stress oxidativo dos neutrófilos....................................52

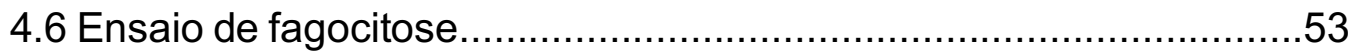

4.7 Produção de NETs em infecção por $F$. pedrosoi..............................54

4.8 Análise da migração dos neutrófilos frente aos estímulos de conídios

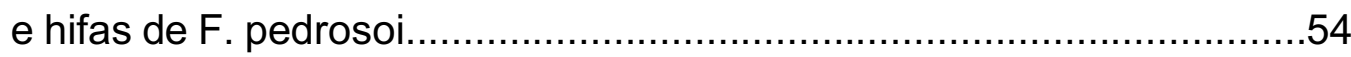

4.9 Infecção intraperitoneal de animais C57BI/6 WT, TLR2-KO e TLR4KO com conídios de F. pedrosoi........................................................55

4.9.1 Análise da carga fúngica no baço e fígado e obtenção de sobrenadante e células dos órgãos.................................................55

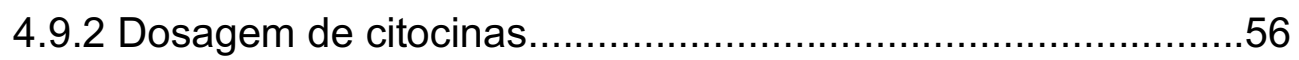

4.9.3 Imunofenotipagem por citometria de fluxo.............................56

4.10 Cultivo do Hibridoma RB6-8C5 para obtenção de anticorpos anti-Gr1

4.10.1 Depleção de neutrófilos em animais C57BI/6. .58

4.11 Infecção intraperitoneal de animais C57BI/6 WT e neutropênicos com conídios de F. pedrosoi. .58

4.11.1 Avaliação da ativação de linfócitos T. .58

4.11.2 Avaliação da produção de anticorpos específicos contra $F$. pedrosoi. .59

5. RESULTADOS 61

5.1 Purificação dos neutrófilos da medula óssea de camundongos C57BI/6.

5.2 Importância dos receptores TLR-2 e TLR-4 na eliminação de conídios e hifas de F. pedrosoi por neutrófilos

5.3 Avaliação do processo de fagocitose na eliminação do $F$. pedrosoi. 
5.4 Avaliação da produção de ROS por neutrófilos infectados com $F$. pedrosoi.

5.4.1 Produção de ROS é importante para eliminação de conídios, mas não de hifas de $F$. pedrosoi. 67

5.5 Hifas de $F$. pedrosoi estimulam a liberação de NETs .68

5.6 Papel do TLR-2 e TLR-4 na migração dos neutrófilos .71

5.7 TLR-2 e TLR-4 são importantes receptores na fase aguda da cromoblastomicose. .71

5.8 Depleção de neutrófilos murinos utilizando anti-Gr1 produzido pelo hibridoma RB6-8C5

5.9 Importância dos neutrófilos em infeções causadas por conídios de $F$. pedrosoi. .75

5.9.1 Imunofenotipagem do baço e fígado dos animais selvagens e neutropênicos na fase aguda da doença.

5.9.2 Citocinas pró e anti-inflamatórias no baço e fígado dos animais WT e neutropênicos na fase aguda da doença

5.9.3 Instauração e disseminação da doença em animais selvagens e neutropênicos.

5.9.4 Análise da Importância dos neutrófilos na fase tardia da doença .78

5.9.5 Análise da produção de anticorpos específicos contra F. pedrosoi após 14 dias de infecção 80

5.9.6 Análise da proliferação de linfócitos após 10 dias de infecção: dos neutrófilos na fase tardia da doença

6. DISCUSSÃO 



\section{INTRODUÇÃO}

\subsection{Cromoblastomicose:}

A cromoblastomicose é uma micose subcutânea crônica e progressiva causada por diferentes gêneros de fungos pertencentes à família Herpotrichiellaceae. Os principais agentes etiológicos da doença são: Fonsecaea pedrosoi, F. monophora, F. nubica, F. pugnacious, Phialophora verrucosa, Cladophialophora carrionii, Rhinocladiella aquaspersa, Exophiala spinifera, Aureobasidium pullulans e Chaetomium funicola $(1,2)$.

O primeiro caso da doença foi observado pelos médicos brasileiros Alexandre Pedroso e José Maria Gomes no ano de 1911 na cidade de São Paulo (3). Durante anos os médicos acompanharam 4 pacientes provenientes do estado de Minas Gerais os quais apresentavam lesões ulcerativas e nodulares na pele, semelhantes às lesões observadas na blastomicose cutânea. As biópsias das lesões apresentaram estruturas fúngicas de coloração amarronzada enquanto colônias filamentosas de coloração negra com aspecto aveludado foram observadas no microcultivo do fungo. Embora as lesões desses pacientes se assemelhassem com as lesões observadas na blastomicose cutânea, a diferença quanto à coloração e ao aspecto das colônias levou Pedroso e Gomes a denominarem a doença de "blastomicose negra". Para a realização da identificação micológica mais precisa, as amostras foram enviadas para Paris. Entretanto, devido aos conflitos históricos da Primeira Guerra Mundial, Pedroso e Gomes publicaram este estudo apenas no ano de 1920 (4). Neste intervalo de 9 anos entre a observação das lesões desses pacientes e a publicação do relato de caso em jornais científicos internacionais, o médico alemão Maximilliano Willibaldo Rudolph, que trabalhava na cidade de Estrela do Sul em Minas Gerais, publicou no ano de 1914 em um jornal alemão o relato de caso de 6 pacientes com lesões verrucosas nos membros inferiores causadas por um fungo negro. Ele denominou a doença de "doença da figueira", por estar relacionado a trabalhadores rurais que trabalhavam no cultivo de figo (5). No ano de 1915, Lane e Medlar relataram a observação de lesões verrucosas com presença de fungo negro em um paciente italiano que morava na cidade de Boston, nos Estados Unidos. Eles denominaram a doença de dermatite verrucosa (ou "nova blastomicose") causada por um fungo negro o qual eles 
denominaram de Phialophora verrucosa. Antes de publicarem o relato de caso dos pacientes infectados com "blastomicose negra", os médicos brasileiros Pedroso e Gomes tiveram conhecimento do trabalho publicado por Lane e Medlar. Por acreditarem se tratar do mesmo agente etiológico, Pedroso e Gomes sugeriram em seu trabalho que os pacientes acompanhados desde 1911 também apresentavam dermatite verrucosa causada por Phialophora verrucosa. Porém, em 1936, o pesquisador argentino Pablo Negroni verificou que o fungo observado nos pacientes brasileiros (tanto por Pedroso e Gomes, quanto pelo médico alemão Dr. Rudolph) era diferente do fungo que fora observado no paciente dos Estados Unidos. Ele então classificou-o como pertencente ao gênero Fonsecaea e, em homenagem aos "descobridores" deste fungo, nomeou a espécie de pedrosoi (6). Pelo fato da publicação do Dr. Rudolph ter sido datada de 1914, por muitos anos creditou-se a ele o primeiro relato da cromoblastomicose. Entretanto, atualmente a comunidade científica credita essa "descoberta" aos médicos brasileiros Pedroso e Gomes, devido ao estudo iniciado em 1911 e publicado em 1920.

Embora os primeiros relatos da doença tenham ocorrido entre $1911 \mathrm{e}$ 1920, o termo cromoblastomicose para designar a micose cutânea causada pelos fungos negros foi sugerido pela primeira vez apenas no ano de 1922 (7). Entretanto, esse termo não foi totalmente aceito na época e diferentes nomes foram utilizados no decorrer dos anos para descrever a cromoblastomicose, sendo os mais comuns: doença da figueira, blastomicose negra, nova blastomicose, dermatite verrucosa causada por Phialophora verrucosa, doença do Pedroso, doença do Fonseca, doença de Lane e Medlar entre outros. No ano de 1935 Moore sugeriu a troca da nomenclatura para cromomicose, alegando que o termo cromoblastomicose indicaria a presença de brotamento de leveduras nas lesões $(4,8)$. Mas foi apenas em 1992 que a Sociedade Internacional de Micologia Humana e animal entrou em consenso de que o termo cromoblastomicose é a nomenclatura correta para designar a doença (9). 
Com o avanço dos estudos, verificou-se que a transmissão da doença ocorre pelo contato de peles abrasivas com as hifas ou conídios presentes no meio ambiente (10). Embora a cromoblastomicose possa ser observada ao redor de todo o mundo, é mais frequente o relato em regiões com clima tropical úmido e subtropical (11-13) como: Brasil (10,14), Madagascar (15), México (16), China e Austrália (4) (Figura 1).

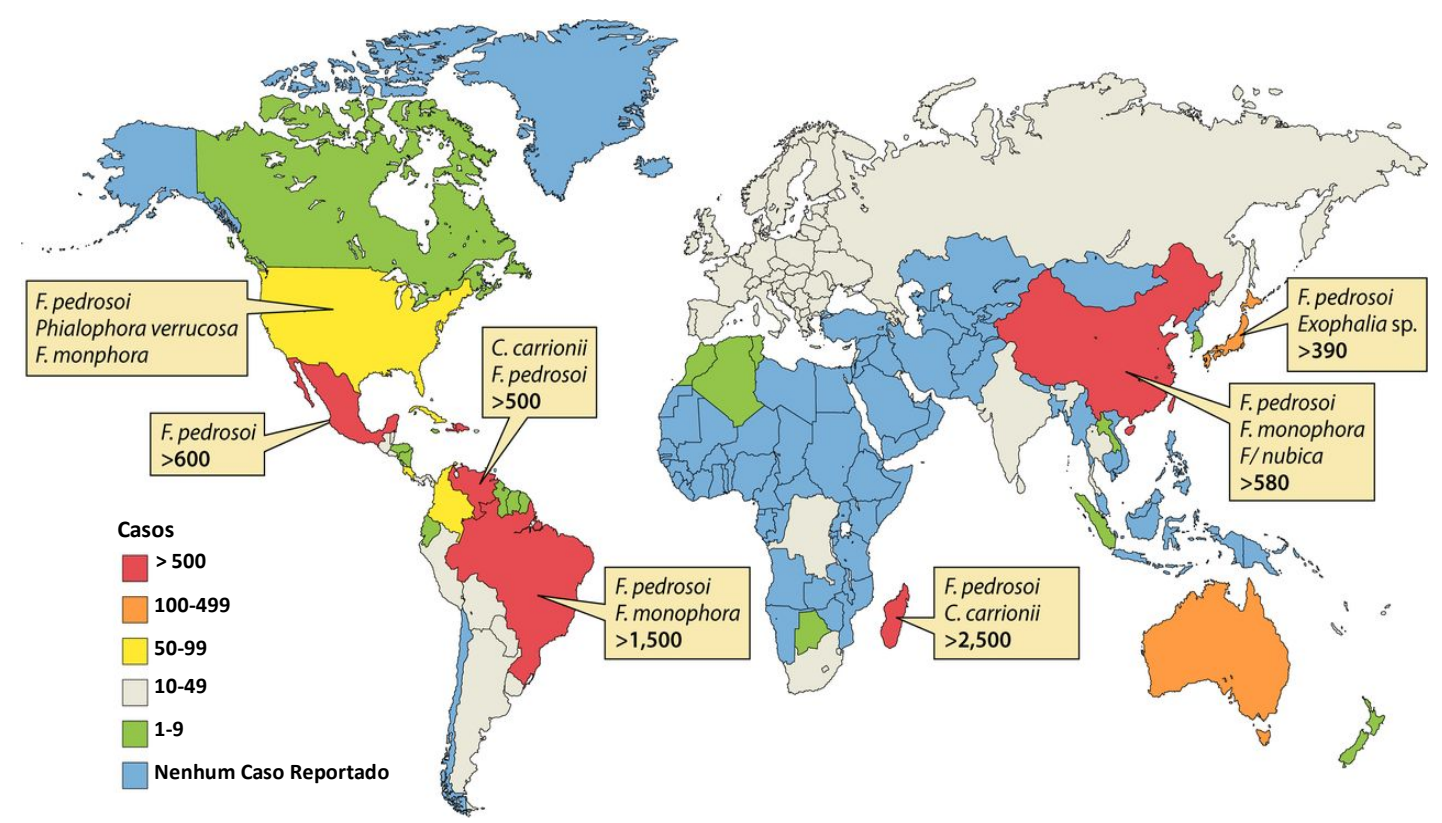

Figura 1 Mapa epidemiológico da Cromoblastomicose: Observamos o relato da doença em todos os continentes, com maior frequência em países de climas tropicais e subtropicais. O Fonsecaea pedrosoi e Cladophialophora carrionii são os agentes etiológicos mais observados na Cromoblastomicose ao redor do mundo. (Figura adaptada de (4)).

A incidência da doença é maior em trabalhadores rurais, devido ao seu constante contato com solo e plantas - habitat natural destes fungos (17). Os pés e as mãos são as áreas mais comumente afetadas nesta doença, entretanto há relatos esporádicos de infecções nas córneas, face, peito e também no abdômen $(11,14,18-20)$. As lesões são caracterizadas inicialmente pelo surgimento de pequenas pápulas verrucosas - devido ao espessamento da epiderme - podendo evoluir para lesões crostosas e exsudativas, geralmente associada às infecções secundárias (Figura 2). 

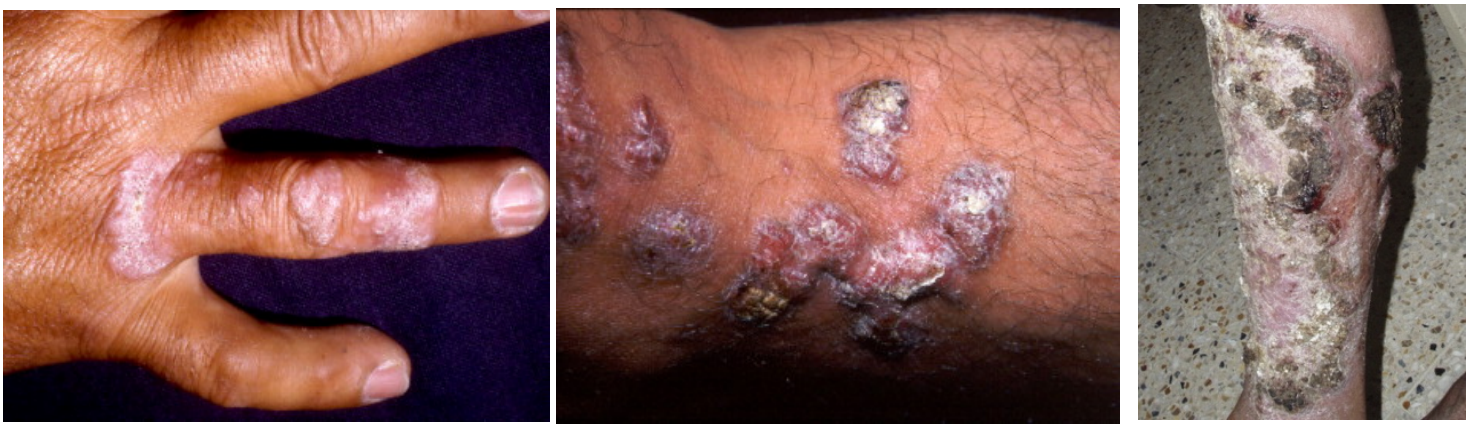

Figura 2 Lesões típicas observadas na Cromoblastomicose: As lesões são frequentemente localizadas nos membros superiores (a e b) e nos membros inferiores (c), regiões do corpo em maior contato com solos e plantas infectados. A presença de pequenas pápulas verrugosas é observada no início da doença (a), podendo evoluir lentamente para lesões do tipo nódulos ou tumores (b). Em casos crônicos da doença, lesões do tipo úlceras com presença de material purulento são observadas (c) (21).

Nos exames histopatológicos observamos um aumento na espessura da camada queratinosa (hiperceratose) e da camada espinhosa (acantose) da epiderme, acompanhado de infiltrado inflamatório composto principalmente por: células fagocíticas mononucleares, neutrófilos e linfócitos $(22,23)$. A presença de granulomas (células gigantes e multinucleadas) é frequentemente observada nas biópsias das lesões (Figura 3).
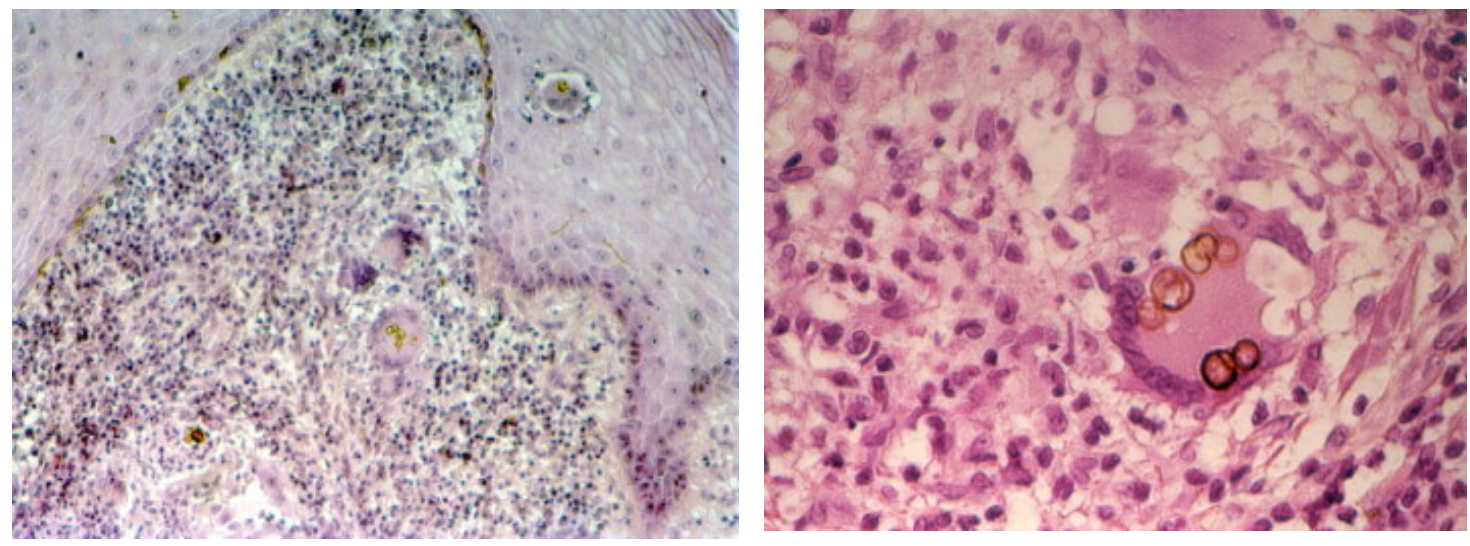

Figura 3 Achados histopatológicos na Cromoblastomicose: Biópsias de pele coradas com hematoxilina e eosina mostram o espessamento da camada espinhosa da epiderme (acantose) com presença de infiltrado inflamatório próximo aos fungos (a). A formação de granuloma (b) é frequentemente observado na tentativa de conter e evitar a disseminação da doença (21).

Atualmente, o tratamento da cromoblastomicose é longo, de alto custo, apresentando eficácia parcial e grandes efeitos colaterais $(17,24)$. Os tratamentos variam entre: prescrição de fármacos anti-fúngicos - sendo que a combinação de dois ou mais fármacos apresentou melhor eficácia (24-26); terapia com calor (Thermoterapy) e frio (Cryoteraphy); e em casos iniciais da doença pode-se ocorrer a intervenção cirúrgica para limpeza e retirada das áreas infectadas pelo fungo (27-29). 
O alto custo é o grande entrave no tratamento da cromoblastomicose, uma vez que sua incidência é maior em populações marginalizadas e de baixa renda. Portanto, estudos devem ser conduzidos buscando o desenvolvimento de novos fármacos e terapias alternativas de baixo custo para que possamos melhorar a eficácia e diminuir os efeitos colaterais e o custo do tratamento da cromoblastomicose.

\subsection{Fonsecaea pedrosoi:}

Embora a cromoblastomicose possa ser causada por diferentes gêneros de fungos, o Fonsecaea pedrosoi é o principal agente etiológico da doença em todo o mundo, inclusive no Brasil $(1,4,30)$. Caracterizado como dimórfico, ele pode ser encontrado no meio ambiente na forma de micélios e/ou conídios (fase saprófita) ou nos tecidos do hospedeiro na forma de corpos escleróticos (fase infecciosa) (Figura 4) (22). Os corpos escleróticos são caracterizados por células esféricas com parede celular espessa e pigmentada sendo altamente resistente aos mecanismos imunológicos do hospedeiro permitindo, portanto, sua sobrevivência e a progressão da doença (31-33).
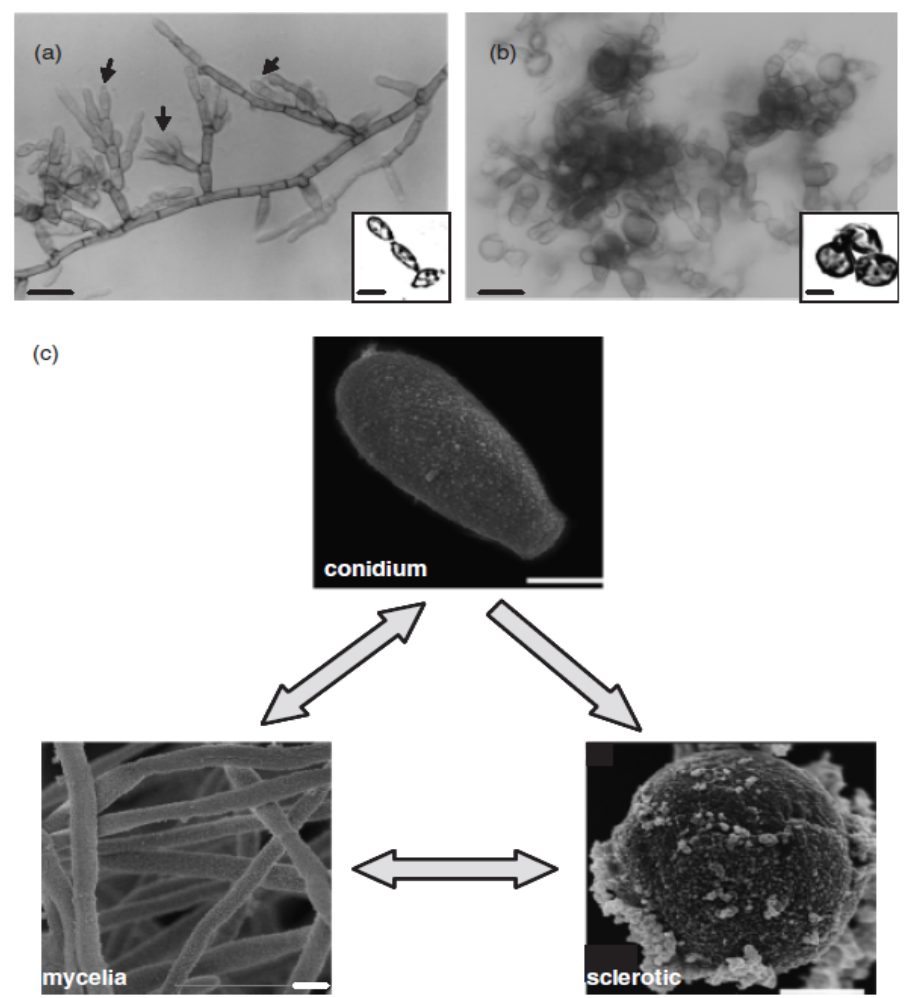

Figura 4 Morfologia do Fonsecaea pedrosoi: Em (a) observamos por meio da microscopia de luz convencional os micélios e os conídios (setas) do fungo. Estas estruturas são observadas na fase saprófita do fungo (meio ambiente) enquanto os corpos escleróticos (b) são estruturas observadas na fase infecciosa (nos tecidos do hospedeiro). Em (c) observamos as formas de conídio, micélios e esclerótica do fungo por microscopia eletrônica de varredura (Adaptado de (22)). 


\subsubsection{Diferenças morfológicas e estruturais entre as diferentes formas do F. pedrosoi:}

Conforme descrito, o $F$. pedrosoi pode apresentar 3 formas morfológicas distintas: Hifas, conídios ou corpos escleróticos. Morfologicamente, essas estruturas apresentam características típicas entre si e distintas umas das outras. Enquanto conídios são estruturas arredondadas/ovaladas com tamanho variando entre 3 a $6 \mu \mathrm{m}$, as hifas consistem em estruturas alongadas e septadas de diversos tamanhos, podendo atingir até $100 \mu \mathrm{m}$ de comprimento (34). Com estrutura arredondada, variando entre 5 a $12 \mu \mathrm{m}$ (33), os corpos escleróticos são estruturas observadas apenas nos tecidos do hospedeiro e pouco se sabe sobre sua formação, como por exemplo, se eles são provenientes dos conídios, das hifas ou de ambos. Entretanto, as diferenças entre as diferentes partículas do $F$. pedrosoi não estão apenas em sua morfologia, mas também na composição estrutural de sua parede. Embora a estrutura organizacional das paredes fúngicas sejam heterogêneas, podendo variar entre gêneros e espécies fúngicas, podemos classificá-las de um modo geral em 2 camadas: 1- Camada interna: Localizada próxima à membrana plasmática; 2- a camada externa: Localizada sobre a camada interna e, portanto, mais distante à membrana plasmática (Figura 5).

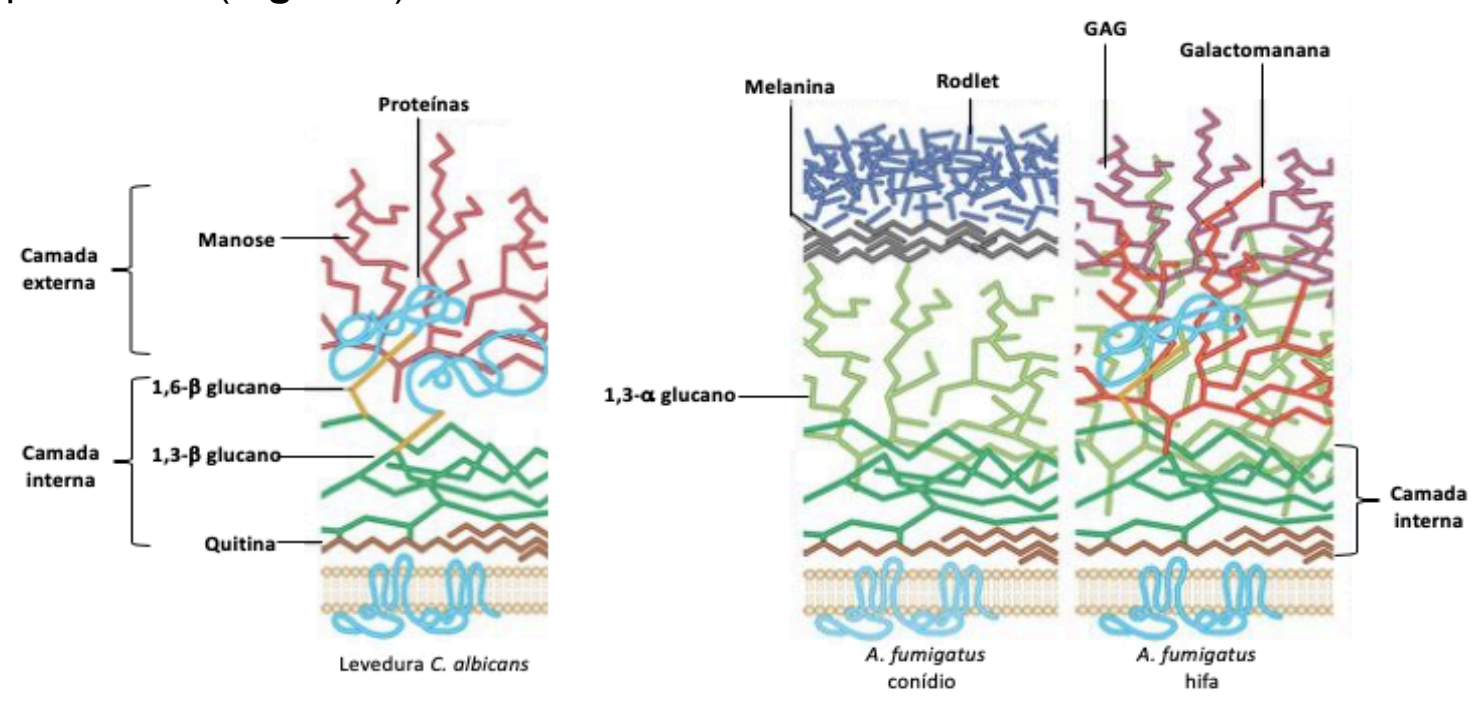

Figura 5 Composição estrutural da parede celular de fungos: Podemos dividir a parede celular em camada interna e camada externa. (Esquerda) A camada interna geralmente apresenta quitina e os $\beta$-glucanos 1,3 e 1,6, que fazem a interação a camada externa, que é majoritariamente composta de proteínas e manose. Entretanto, os componentes das camadas internas e externa podem variar dentro da mesma espécie, sofrendo diversas alterações nas diferentes formas do fungo, como por exemplo conídios e hifas (Direita). A camada externa da parede celular de conídios de $A$. fumigatus apresentam componentes como a melanina e Rodlet, entretanto as hifas do fungo apresentam em sua camada externa componentes como as galactomananas e galactosaminoglicanas (GAG) (Figura adaptada de (34)). 
A camada interna apresenta uma estrutura mais conservada entre as diferentes espécies fúngicas, sendo geralmente composta por quitina ligada à polissacarídeos do tipo 1,3- $\beta$ glucano e, em menor quantidade, à polissacarídeos do tipo 1,6- $\beta$ glucano. Esta camada é um importante componente estrutural da parede celular, sendo responsável pela manutenção do formato do exoesqueleto e da estrutura da parede celular. Ela está ligada às proteínas e a outros tipos de carboidratos - como por exemplo às manose - que compõem a camada externa da parede celular. Esta camada apresenta uma maior heterogeneidade entre as espécies e também entre as diferentes formas do patógeno. Os fungos melanizados, como por exemple o F. pedrosoi e A. fumigatus, apresentam melanina na composição da camada externa da parede celular (34). No caso dos agentes etiológicos da cromoblastomicose, as altas concentrações de melanina conferi-lhes a coloração amarronzada/negra, característica ímpar desses fungos (35).

A composição da camada externa da parede celular pode sofrer alterações sutis em determinados fungos, mas pode também apresentar uma enorme diferença entre a estrutura vegetativa (hifas) e a reprodutiva (conídios) de um mesmo fungo, como observado no A. fumigatus (Figura 5). Infelizmente, pouco é conhecido sobre as diferenças na composição das paredes das diferentes partículas do F. pedrosoi, sendo mais comum observarmos trabalhos comparando a parede dos conídios à das hifas, mas não à parede dos corpos escleróticos. Um dos primeiros estudos nesta área demonstrou a presença dos ácidos siálicos $\mathrm{N}$-acetilneuramínico e $\mathrm{N}$-glicolilneuramínico na parede de $F$. pedrosoi, sendo a expressão do N-glicolilneuramínico predominante em conídios enquanto a expressão do ácido $\mathrm{N}$-acetilneuramínico é predominante expresso nas hifas (36). Na década de 90, outros dois importantes trabalhos sobre o estudo dos carboidratos e lipídios presentes nessas partículas foram publicados $(37,38)$. Eles demonstraram a presença de carboidratos de glicose, manose, galactofuranose, ramnose e glucosamina na parede dos conídios e hifas de $F$. pedrosoi. Embora os tipos de carboidratos presentes nas paredes dessas partículas fossem os mesmos, a quantidade deles variava entre as diferentes formas do fungo, sendo a ramnose predominante nos conídios e a galactofuranose predominante nas hifas de F. pedrosoi. Em relação aos lipídios, observou-se uma maior quantidade total deste composto nos conídios em 
relação às hifas, sendo o ácido palmítico, esteárico e oileico presentes tanto nos conídios quanto nas hifas de F. pedrosoi. Contudo, a presença dos ácidos aracdônico e linoleico foi observada exclusivamente nos conídios e hifas, respectivamente $(37,38)$.

Portanto, diversos fatores podem influenciar na ativação da resposta imunológica frente à infecção por fungos dimórficos e/ou filamentosos, sendo a composição estrutural da parede e a diferença no tamanho das diferentes estruturas fúngicas (como dos conídios e hifas) dois importantes fatores.

\subsection{Sistema imunológico:}

O sistema imunológico é formado por órgãos, tecidos, vasos, células e proteínas responsáveis pela homeostasia e defesa do organismo contra patógenos e agentes externos. Didaticamente, podemos dividi-lo em: sistema imune inato e sistema imune adaptativo.

\subsubsection{Sistema imune inato (SII):}

O sistema imune natural ou inato é evolutivamente mais antigo que o sistema imune adaptativo e constitui a primeira linha de defesa do nosso organismo (39). Ele recebe este nome, está presente e atuante desde o momento do nosso nascimento, enquanto o sistema imune adaptativo é desenvolvido ao longo de nossa vida. O SIl pode ser observado nos nossos ancestrais mais antigo, como as esponjas, cujo aparecimento no planeta Terra data de aproximadamente 700 milhões de anos (40). Ele é composto principalmente pelas barreiras físicas (pele e mucosas), químicas ( $\mathrm{pH}$, peptídeos e proteínas) e biológicas (células brancas ou leucócitos). Os leucócitos compreendem as células fagocíticas (neutrófilos, monócitos/macrófago e células dendríticas) e não fagocíticas (basófilos, eosinófilos, mastócitos e natural killer) (41). Os peptídeos, como catelicidinas e defensinas, e as proteínas, como as citocinas e as pertencentes ao Sistema Complemento (SC), são importantes componentes da barreira química deste sistema (42). Por muitos anos, classificou-se o SII como um sistema que apresenta baixa especificidade e incapacidade de gerar memória imunológica $(43,44)$. Entretanto, em 2011 Netea e colaboradores sugeriram que a imunidade inata era capaz de gerar memória imunológica, a qual eles denominaram de "imunidade treinada" (45). Como 
qualquer descoberta recente, a aceitação e divulgação da imunidade treinada pela comunidade científica ainda é restrita, sendo refutada por muitos pesquisadores ao redor do mundo (para revisão do assunto ver (46)). Outra característica do SII é a baixa especificidade, devido ao fato das suas células reconhecerem apenas padrões moleculares presentes nos patógenos (como por exemplo o lipopolissacarídeo (LPS), presente em todas as bactérias Gramnegativas) não sendo capaz de reconhecem estruturas específicas dos patógenos (47). Este reconhecimento dos Padrões Moleculares Associados aos Patógenos (PAMPs, do inglês Pathogen Associated Molecular Patterns) ocorre via Receptores de Reconhecimento Padrão (PRRs, do inglês Pattern Recognition Receptors) presentes nas superfícies e/ou citoplasma das células do SII. Alguns exemplos de PRRs descrito até o momento são: Receptores Semelhantes ao Nod (NLR, do inglês Nod-like receptors), Receptores de Lectina do tipo C (CLR, do inglês C-type lectin receptors) e os Receptores semelhantes ao Toll (TLR, do inglês Toll-Like Receptors), sendo estes um dos mais importantes e estudados até o momento (48) (49).

\subsubsection{Receptores de reconhecimento padrão: Toll-Like Receptors:}

Em 1989, ao ministrar uma palestra no "Cold Spring Harbor meeting", Charles Janeway sugeriu enfaticamente que os sinais co-estimulatórios necessários para ativação das células $\mathrm{T}$ seriam provenientes de células apresentadoras de antígenos (APC do inglês Antigen Presenting Cells), as quais apresentariam uma super expressão (upregulation) dos sinais co-estimulatórios após o reconhecimento, fagocitose e processamento de antígenos (50). Desta forma, ele especulou que as APCs deveriam apresentar receptores que reconhecessem estruturas inerentes aos patógenos, usando pela primeira vez 0 termo "Receptores de Reconhecimento Padrão" (PRRs) e "Padrões Moleculares Associados aos Patógenos" (PAMPs) para designar, respectivamente, os receptores e as estruturas reconhecidas por ele. Ele ainda postulou que os PAMPs deveriam apresentassem as seguintes características para que fossem reconhecidos pelos PRRs: 1- ser exclusiva de patógenos, para que o sistema imune conseguisse distinguir o próprio do não próprio; 2- estar associada a componentes essenciais dos microrganismos, evitando assim que o mesmo 
possa sofrer mutações para "eliminar" tal molécula como forma de evadir o sistema imune do hospedeiro; 3- ser conservada entre os diferentes tipos de microrganismos, permitindo que um número limitado de PRRs reconhecessem uma enorme quantidade de patógenos $(50,51)$. Embora o termo PRR tenha sido utilizado pela primeira vez no ano de 1989, foi apenas na década de 90 que os primeiros trabalhos foram publicados demonstrando a existência de tais receptores.

O TLR foi o primeiro PRR descrito, e recebeu este nome pois apresenta estrutura semelhantes ao receptor Toll observado primeiramente na Drosophila melanogaster. Estudos realizados na da década de 80, mostraram a importância do gene toll no desenvolvimento dorso-ventral da $D$. melanogaster $(50,52)$. $\mathrm{Na}$ década de 90 , utilizando $D$. melanogaster mutantes para o gene do toll, Jules Hoffmann e colaboradores verificaram a importância deste gene na proteção às infecções fúngicas. Eles sugeriram que este gene também era responsável pela expressão de receptores Toll, os quais eram parte do SIl das drosophilas sendo responsáveis pelo reconhecimento e eliminação dos fungos (53). Neste mesmo período, Charles Janeway e Ruslan Medzhitov identificaram a presença de receptor homólogo ao Toll no genoma humano nomeando-o, portanto de "Receptor semelhante ao Toll". Eles então clonaram essa proteína e introduziram uma mutação que gerava uma proteína constitutivamente ativa. Ao transfectar células de linhagem com essa proteína mutante, eles verificaram um aumento na expressão de molécula co-estimulatória B7.1, necessária para ativação de células T naives (54). No ano de 1998, o grupo do Dr. Bruce Beutler identificou que o TLR4 era responsável pelo reconhecimento do LPS, presente em bactérias Gram-negativas. Como já era conhecido naquela época que a ativação da resposta imune frente ao LPS poderia levar ao choque séptico, o trabalho do Dr. Beutler demonstrou pela primeira que o reconhecimento de PAMPs pelo TLR apresentava uma relevância biológica indiscutível (55). Para que se tenha uma ideia da importância da descrição dos receptores do tipo Toll para a ciência moderna, o trabalho publicado pelo grupo da Dra Christiane Nusslein-Volhard, o qual descreveu o papel do gene do toll no desenvolvimento dorso-ventral de Drosophila, recebeu o prêmio Nobel de medicina no ano de 1995. Quase duas décadas depois, em 2011, o Dr. Jules Hoffmann e o Dr. Bruce Beutler receberam o prêmio Nobel de fisiologia e medicina pelos trabalhos que 
comprovaram a importância do TLR frente à infecção fúngica em drosophila e o reconhecimento do LPS pelo TLR4, respectivamente. Após os trabalhos pioneiros na descrição e caracterização do TLR, inúmeros grupos ao redor do mundo têm realizado diversos estudos para melhor entendimento dos PRRs. Até o momento 10 TLRs foram descritos em humanos e 12 em camundongos, sendo o TLR 2 e o TLR 4 um dos mais estudados até o momento (56-58) (Tabela 1).

Tabela 1: Ligantes dos receptores TLR-2 e TLR-4

Receptor

TLR-2 Peptideoglicano, fosfolipomanana, glicolipidio, zymosan, ácido lipoteicóico e 1,4 glucano

TLR-4

\section{Ligante}

Lipopolissacarídeo, fosfolipídio, Manana e Ramnose

Embora possamos dividir a resposta imune em inata e adquirida, sabe-se que a interação entre esses dois sistemas é essencial para o desenvolvimento de uma resposta imune mais eficaz $(59,60)$. As células dendríticas (o inglês Dendritic Cells - DC) são umas das principais células envolvida na interação da resposta imune inata e resposta imune adquirida. Elas são denominadas células apresentadoras de antígenos (do inglês Antigen Presenting Cells - APCs) profissionais, pois capturam e processam os microrganismos, apresentando seus peptídeos processados em suas moléculas do complexo principal de histocompatibilidade (do inglês Major Histocompatibility Complex - MHC) classe I ou classe II. Os peptídeos presentes no MHC classe I é apresentado exclusivamente para linfócitos $\mathrm{T} \mathrm{CD8}^{+}$, enquanto os peptídeos presentes no MHC classe II é apresentado exclusivamente para linfócitos T CD4 ${ }^{+}$. Desta forma, as DCs auxiliam a ativação do sistema imune adaptativo, sendo descritas como células responsáveis por realizar a interação do sistema imune inato e o sistema imune adaptativo (61).

\subsubsection{Sistema imune adaptativo (SIA):}

Evolutivamente o SIA surgiu posteriormente ao SII, sendo observado pela primeira vez nos vertebrados amandibulados há aproximadamente 500 mihões de anos. Este sistema é composto principalmente por linfócitos T e B e seus 
produtos. Suas principais características são a alta especificidade, diversidade, especialização e geração de memória imunológica (62).

Os linfócitos B são importantes células relacionadas ao desenvolvimento da resposta imune humoral, levando a produção de anticorpos pelas células plasmocitóides. Eles podem fazer o reconhecimento direto de pequenas partículas livres nos órgãos linfoides secundários ou, na grande maioria das vezes, reconhecer antígenos em seu estado nativo (não processado) presentes na superfície de células APCs (reconhecimento indireto) (63). Dependendo da natureza do estímulo - proteico ou não proteico - a ativação dos linfócitos B pode ocorrer - respectivamente - de forma dependente ou independente de linfócitos $\mathrm{T}$. Em caso de estímulo não proteico os linfócitos B são ativados rapidamente, liberando grandes quantidades de imunoglobulinas do tipo IgM (enquanto que em caso se estímulos proteicos as células $B$ interagem com os linfócitos T via MHC classe II (64-66). Os linfócitos T apresentam a subpopulação $\mathrm{CD}^{+}$(auxiliar) e CD8+ (citotóxicos). Enquanto estas células reconhecem antígenos apresentados pelas APCs via MHC I, levando a lise direta da célula, o linfócito T auxiliar reconhece antígenos apresentados via MHC II. Após o reconhecimento, estes linfócitos são ativados podendo secretar diversas citocinas que direcionarão a resposta imune para uma melhor eliminação do patógeno (67). Deste modo, as respostas imunes inata e adquirida estão intimamente associadas ao desenvolvimento de uma resposta imune eficaz no combate aos diversos patógenos.

\subsection{Resposta imunológica na Cromoblastomicose:}

Desde a descrição da cromoblastomicose no início do século $X X$, trabalhos vêm sendo realizados para melhor entendimento da interação patógeno hospedeiro. Embora mais de 100 anos tenha se passado desde a sua descoberta, pouco se sabe sobre como nosso sistema imune reconhece e combate este fungo e muito se deve à falta de um modelo experimental que reproduza a doença humana com sucesso. Para melhor entendimento da resposta imune na cromoblastomicose, dividiremos está secção em 2 partes, distinguindo a resposta imune inata da resposta imune adaptativa nesta doença.

\subsubsection{Resposta imune adaptativa:}


Um dos primeiros trabalhos documentado sobre a cromoblastomicose murina observou a presença de fungos vivos no cérebro, fígado, pulmão, coração, baço e rins de camundongos após aproximadamente 10 dias de infecção. Neste trabalho, o autor sugeriu que a resposta imune celular aparentava ter maior importância no controle da doença quando comparada à resposta imune humoral (68). Entretanto, a importância dos linfócitos $T$ no combate à cromoblastomicose foi confirmada pela primeira vez em ensaios utilizando animais nude (animais deficientes em células T). Esses animais apresentavam maior disseminação e gravidade das lesões, com remissão e cura da doença após transferência e reconstituição da população de células T (69). Posteriormente, nosso grupo verificou que pacientes com a forma mais grave da cromoblastomicose apresentavam maior índices de IL-10 e menor índices de IFN- $\gamma$ e proliferação de linfócitos $T$ quando comparado aos pacientes com a forma mais branda da doença $(70,71)$. A importância do IFN- $\gamma$ foi confirmada utilizando animais $\mathrm{T} \mathrm{CD} 4^{+}$knockout (KO), aonde esses animais apresentaram um aumento da carga fúngica nos órgãos alvos, uma menor resposta de hipersensibilidade do tipo tardia e menores índices na produção de IFN- $\gamma$. Animais $\mathrm{T} \mathrm{CD8}^{+}$knockout também foram utilizados neste trabalho, entretanto nenhuma alteração da doença foi observada em relação ao animal wild type (WT) (72). Recentemente, foi verificado o acúmulo de citocina IL-17 nas lesões de pele dos camundongos infectados (73) e, em trabalho subsequente, verificouse que o F. pedrosoi estimula a diferenciação de células Th17. Entretanto não há trabalhos demonstrando a real importância dessa subpopulação no combate à cromoblastomicose $(74,75)$.

Enquanto a imunidade celular tem se mostrado importante no combate a cromoblastomicose, o papel da imunidade humoral ainda é discutível. Trabalhos in vitro demostram a importância dos anticorpos na eliminação do $F$. pedrosoi. No final da década de 80 , verificou-se que anticorpos IgG específicos para antígenos de $F$. pedrosoi apresentavam a capacidade de diminuir o crescimento do fungo em 50 a $60 \%$ (76). Posteriormente, verificou-se que anticorpos contra a melanina presente na parede do $F$. pedrosoi apresentam capacidade de inibição direta no crescimento do fungo in vitro, e estimulava o aumento da fagocitose, da produção do burst oxidativo e da atividade microbicida dos 
neutrófilos humanos (77). Mais recentemente, estudo realizado em animais deficientes de células B (animas Xid) mostrou uma maior gravidade da doença nesses animais demonstrando, portanto, a importância das células B e dos anticorpos na cromoblastomicose (78). Entretanto, estudos com pacientes tiveram dados conflitantes quanto a importância da resposta imune humoral no combate à esta doença. Enquanto Esterre e colaboradores verificaram que os níveis de anticorpos lgG específicos estão diretamente relacionados à gravidade da doença (79), Gimenez e colaboradores (70) não observaram nenhuma relação dos níveis de anticorpos em relação à evolução da doença.

Deste modo, acredita-se que a imunidade celular seja mais importante que a imunidade humoral na contenção e eliminação do $F$. pedrosoi, sendo o perfil Th1 e a maior proliferação celular relacionado à casos mais brandos da doença, enquanto o perfil Th2 e uma menor proliferação celular está relacionado à casos mais graves de cromoblastomicose.

\subsubsection{Resposta imune inata:}

A resposta imune inata frente ao $F$. pedrosoi tem sido mais estudada quando comparada à resposta imune adaptativa. Em 1984, Torinuki e colaboradores observaram a ativação da via alternativa do SC sob a forma esclerótica do F. pedrosoi (80). Posteriormente, verificou-se também que a ativação da via alternativa do SC sobre conídios e micélios do fungo ocorria sobre a melanina presente em sua parede $(81,82)$. Entretanto, o papel do SC na eliminação deste fungo ainda é desconhecido.

Os macrófagos são outro importante componente do sistema imune inato na contenção e eliminação de patógenos. Experimentos in vitro demonstram que macrófagos-residentes de camundongos atuam fagocitando os conídios de $F$. pedrosoi entretanto, esses macrófagos não apresentam capacidade fungicida e nem fungiostática e os conídios internalizados continuam vivos se transformando em hifas o que leva a ruptura mecânica da membrana plasmática do macrófago levando à morte dessas células (83). Entretanto, verificou-se que macrófagos ativados previamente com IFN- $\gamma$, apresentam função fungiostática, retardando 0 crescimento dos túbulos germinativos e das hifas deste fungo (84). Em 2006, nosso grupo observou o papel destas células frente aos diferentes agentes etiológicos da cromoblastomicose (85). Embora as espécies $F$. pedrosoi e $R$. 
aquaspersa tenham induzido maior índice fagocítico nos macrófagos, o $F$. pedrosoi foi capaz de inibir a produção de óxido nítrico se mostrando resistente à morte pelos macrófagos. Posteriormente, Bocca et al., também verificaram a capacidade do F. pedrosoi em inibir a síntese de óxido nítrico (NO), mesmo na presença de IFN- $\gamma$ e LPS, sugerindo que a produção de NO é importante fator na morte deste fungo (86).

Outra célula essencial do SII é a DC, entretanto seu papel no combate ao F. pedrosoi é controverso. Em 2007, da Silva e colaboradores verificaram que os conídios eram capazes de inibir a expressão das moléculas co-estimulatórias CD40 e B7.2 nas DCs da pele (células de Langerhans), influenciando negativamente a ativação dos linfócitos T (87). Entretanto, em 2009 nosso grupo demonstrou que células dendríticas derivadas de monócitos de pacientes, na presença de conídios de F. pedrosoi, apresentavam uma regulação positiva nas moléculas de HLA-DR e nas moléculas co-estimulatórias CD86, levando a diferenciação da subpopulação Th1 de linfócitos T naives (88). Portanto, mais estudos são necessários para que se entenda a real importância desta célula no combate a cromoblastomicose.

Uma importante célula do SII no combate a infecções fúngicas é o neutrófilo. Embora diversos trabalhos já tenham demonstrado a importância desta células no combate à infecções por Aspergillus fumigatus, Candida albicans, Paracoccidioides brasiliensis (89-92), seu papel no combate ao $F$. pedrosoi ainda é pouco conhecido. Ao contrário dos macrófagos, que não conseguem eliminar o fungo fagocitado, verificou-se que os neutrófilos apresentam alta atividade microbicida frente aos conídios de F. pedrosoi (93) e que seu índice fagocítico é aumentado na presença de anticorpos anti-melanina (77). Em 2011, Machado e colaboradores utilizaram diferentes formas de $F$. pedrosoi para infectar os camundongos e observaram, em infecções por conídios e corpos escleróticos, um grande infiltrado inflamatório de macrófagos (regiões mais periféricas) e de neutrófilos (região central) com a presença de corpúsculos destruídos ou muitas vezes a ausência dos corpos escleróticos na região neutrofílica. Entretanto, quando analisada a região rica em macrófagos, eles observaram grandes quantidades de partículas intactas do fungo. Ao realizar à infecção com hifas de F. pedrosoi eles verificaram um maior infiltrado neutrofílico com grandes quantidades de neutrófilos degenerados (94). 
Recentemente, Ogawa e colaboradores tiveram achados parecido, aonde foi observada um alto infiltrado inflamatório neutrofílico em lesões contendo hifas do F. pedrosoi (95). Embora diversos trabalhos relatem a presença de um exsudato rico em neutrófilos em infecções por $F$. pedrosoi, raros são os trabalhos que aprofundaram o estudo dessas células a fim de verificar seu real papel na contenção e eliminação deste fungo.

Uma das áreas da imunidade inata que mais tem se destacando nos últimos anos são os PRRs e seu ligantes. Entretanto, pouco se sabe sobre estes receptores na identificação do F. pedrosoi. Diversos estudos têm demonstrado o papel dos receptores CLR no reconhecimento de fungos, sendo o Dectina-1 $(96,97)$, Dectina-2 $(98,99)$ e MINCLE $(100-102)$ os CLRs mais estudados até o momento. Estudos demonstram que esses receptores CLRs são capazes de reconhecer o F. pedrosoi e F. monophora. Entretanto, enquanto os receptores Dectina-1 (103) e Dectina-2 (74) atuam ativando as células do sistema imune e estimulando, respectivamente, uma resposta do tipo Th1 e Th17, o receptor MINCLE aparenta ser utilizado pelo fungo como mecanismo de evasão do sistema imune, uma vez que ele é responsável pela inibição da produção de IL12 inibindo, portanto, a diferenciação de células Th1 (104). Embora o papel do MINCLE também tenha sido observado na inibição da diferenciação de células Th17, o mecanismo pelo qual ele está atuando nesta inibição é desconhecido até o momento (104).

Embora os TLRs sejam um dos PRRs mais estudados em diversas infecções, há apenas 2 estudos sobre estes receptores em infecções por $F$. pedrosoi. Sousa e colaboradores sugerem que o F. pedrosoi apresenta baixa capacidade de ativação dos TLRs, uma vez que a ativação prévia do TLR-4 (via injeções de LPS) acarretava numa melhora do clearence fúngico e do combate à doença (104). Entretanto, animais myd88-KO apresentaram piora no desenvolvimento da cromoblastomicose (104). Em estudo mais recente, verificou-se um aumento na expressão gênica de tIr2 e cd14 em macrófagos estimulados in vitro com corpos escleróticos, embora nenhuma diferença na expressão desses genes tenha sido observada após estímulo com conídios de F. pedrosoi (105). Este dado, sugere que os receptores do tipo toll poderiam estar envolvidos no reconhecimento e eliminação dos corpos escleróticos. 
Portanto, maiores estudos são necessários para o melhor entendimento da importância dos TLRs no combate à cromoblastomicose.

\subsection{Neutrófilos:}

Os neutrófilos são importantes células do SII no combate a diversas infecções fúngicas $(106,107)$, entretanto seu papel na cromoblastomicose ainda não é totalmente conhecido. Os neutrófilos representam entre $50 \%$ e $70 \%$ de todos os leucócitos presentes no sangue humano e sua sobrevida é de aproximadamente 8 a 12 horas no sangue e 1 a 2 dias nos tecidos (108). Desta forma, em condições normais nosso organismo produz por dia uma média de $10^{11}$ neutrófilos e, na presença de infecção, essa produção é elevada para $10^{12}$ por dia (109-112). Em camundongos, a porcentagem de neutrófilos no sangue é de apenas 12 a 20\% (entre 1 a 2 milhões), sendo os linfócitos B o leucócito de maior abundância. Entretanto, a medula óssea desses animais apresenta em torno de $1,2 \times 10^{8}$ neutrófilos maduros e, em caso de estímulo, eles são rapidamente liberados para a corrente sanguínea e mobilizados ao local infeccioso (113).

Após geração na medula óssea, os neutrófilos alcançam a corrente sanguínea e circulam por todo o organismo. Em caso de infecção, os neutrófilos migram da corrente sanguínea para o sítio inflamatório e esse processo depende de múltiplos eventos como: 1) adesão "fraca" ao endotélio; 2) rolamento sobre o endotélio; 3) adesão "forte" ao endotélio; 4) transmigração endotelial ou diapedese e 5) mecanismos efetores na eliminação do patógeno (112) (Figura 6).

\subsubsection{Principais mecanismos efetores dos neutrófilos}

Após a migração para o foco inflamatório/infeccioso, os neutrófilos reconhecem as partículas estranhas (por meio de seus PRRs), se ativam e eliminam os corpos estranhos por diferentes mecanismos efetores, como a fagocitose; liberação de grânulos; e a liberação das NETs (do inglês Neutrophil Extracelluar Traps). 


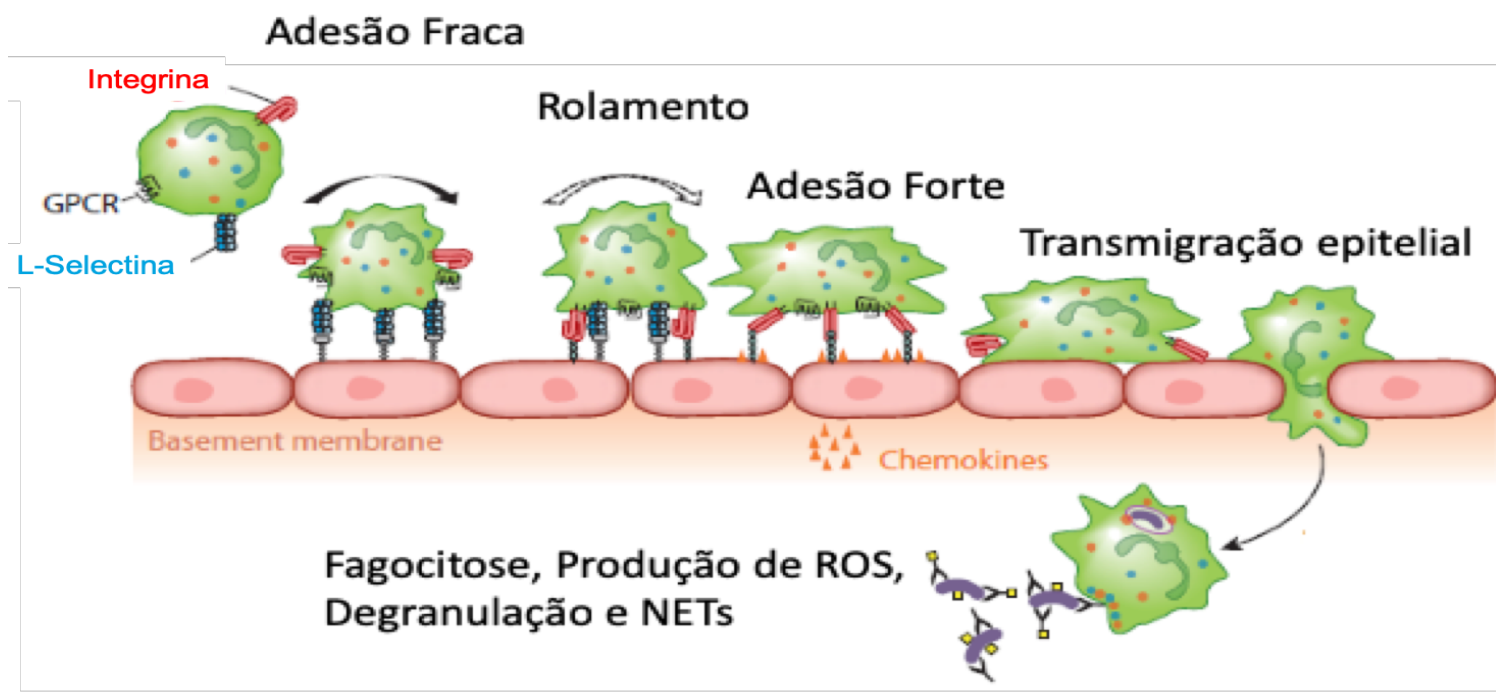

Figura 6 Sequência de eventos necessários para o recrutamento de neutrófilos: Em resposta aos patógenos e as citocinas liberadas por células residentes, as células endoteliais aumentam a expressão de selectinas que interagem com os seus ligantes presentes nos neutrófilos realizando a ligação fraca do neutrófilo ao endotélio e o seu rolamento. As ligantes de integrinas presentes no endotélio interagem, fracamente, com as integrinas constitutivas dos neutrófilos, pois estas apresentam uma conformação com baixa afinidade aos seus ligantes. Porém uma vez que os neutrófilos estão em contato com quimiocinas, as integrinas mudam sua conformação para que sua afinidade aos ligantes aumente, garantindo assim uma forte adesão desta célula ao endotélio. A transmigração endotelial ocorre por meio de quimiotaxia - devido a quimiocinas como a CXCL8 - finalizando assim o processo de recrutamento de neutrófilos ao foco inflamatório/infeccioso (Adaptado de(112)).

\subsubsection{Fagocitose}

A fagocitose é uma das principais funções dos neutrófilos e pode ocorrer pelo reconhecimento de: 1) partículas opsonizadas por anticorpos (receptor para porção Fc de imunoglobulinas $\operatorname{lgG}$ ) ou proteínas do SC (receptores para C3b e iC3b) ou 2) PAMPs, por meio da interação PRRs-PAMPs (exemplo: receptores de lectinas do tipo C e TLR) $(114,115)$ (Figura 7$)$.
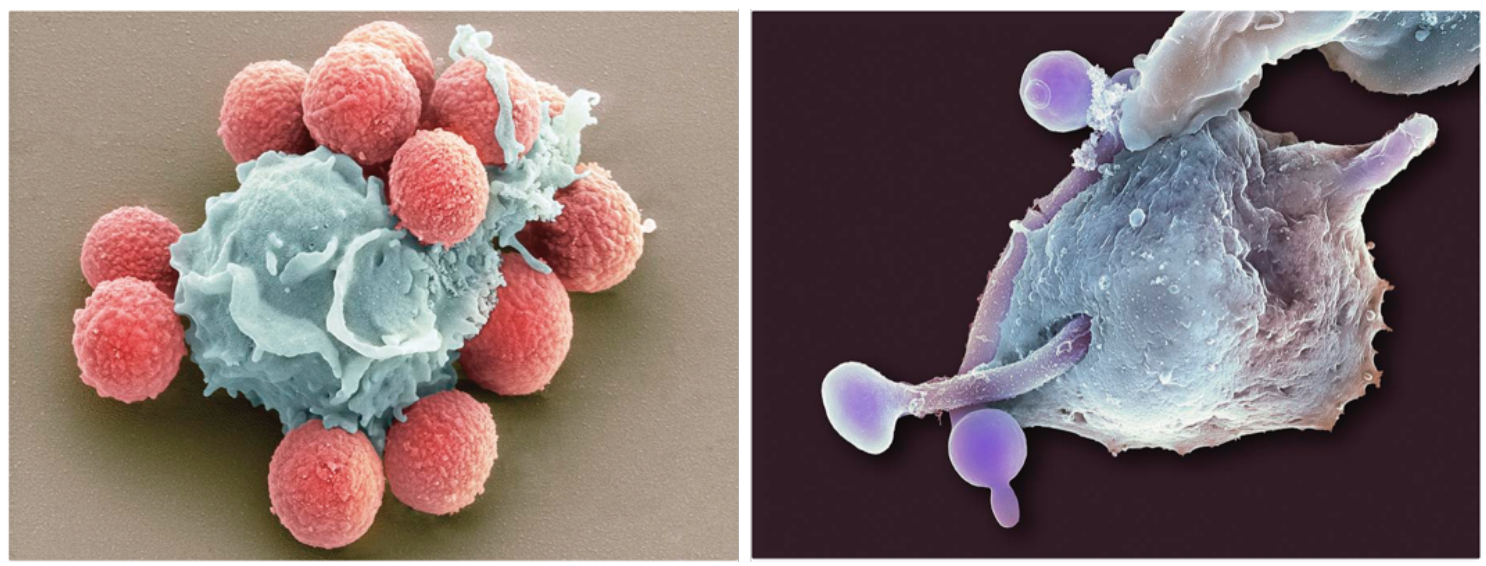

Figura 7 Processo de fagocitose de organismos estranhos por neutrófilos: Imagens de microscopia eletrônica de varredura mostrando o processo de fagocitose de esporos de A. fumigatus (esquerda) e pseudo-hifas de C. albicans (direita) por neutrófilos humanos (imagens obtidas em www.pixels.com/featured/2phagocytosis-of-fungal-spores-prof-matthias-gunzer.html e www.fineartamerica.com/featured/4-neutrophil-engulfingthrush-fungus-sem-.html) 
Uma vez ocorrida a fagocitose, o fagossomo se funde à vesícula lisossômica formando o fagolisossomo e o processo chamado de explosão respiratória (burst oxidativo) se inicia (116).

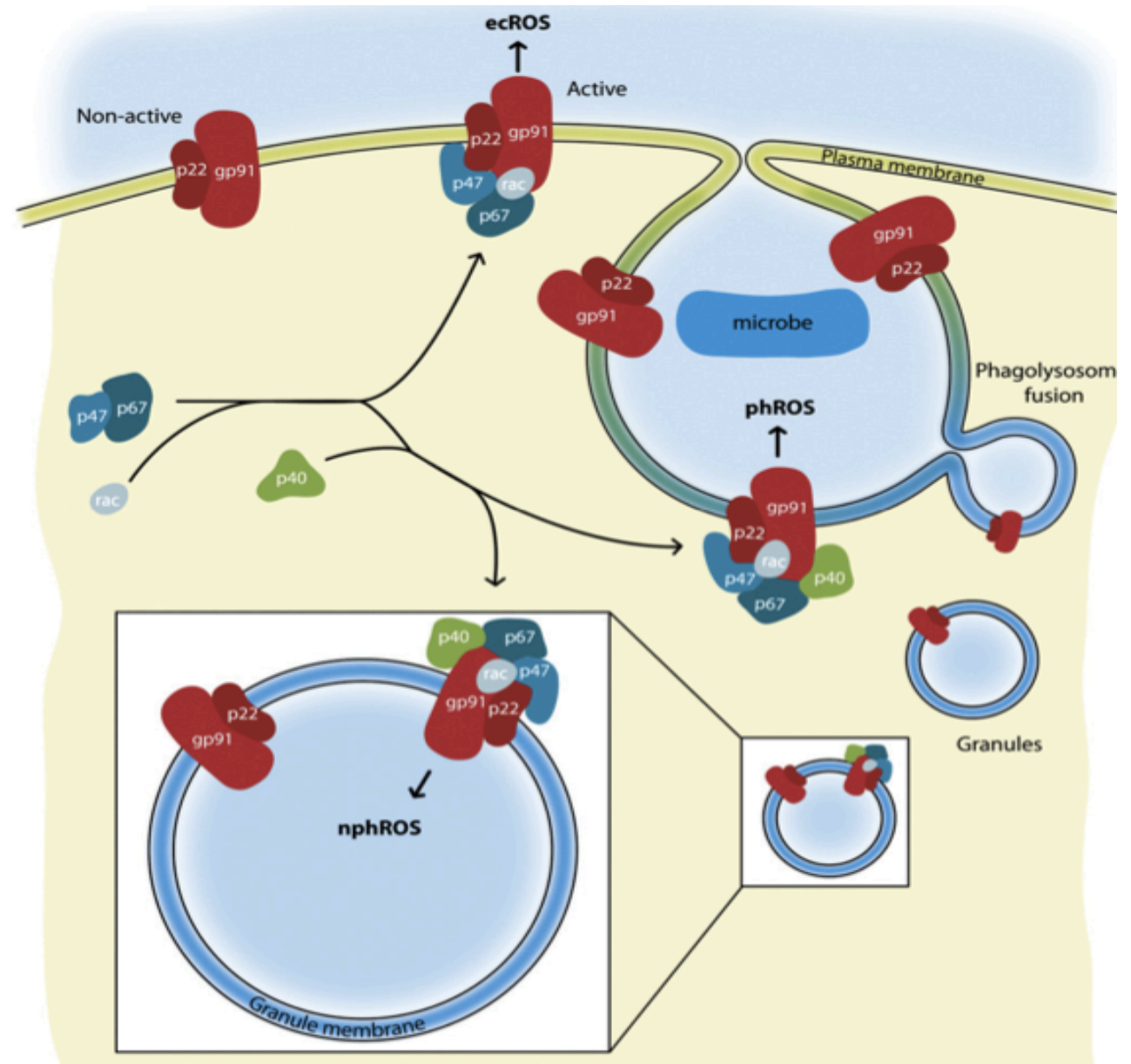

Figura 8 Formação e localização da fagócito oxidase: A fagócito oxidase é composta pelas subunidades protéicas p22, gp91, p40, p47, p67 e rac e pode estar presente nas membranas citoplasmáticas produzindo ROS extracelular (ecROS) - membrana fagocítica - produzindo ROS fagocícito (phROS) - ou na membrana dos grânulos - produzindo ROS não fagocítico (nohROS). A fagócito oxidase presente na membrana citoplasmática não apresenta a proteína p40 na sua formação (Adaptado de (117)).

O burst oxidativo é um processo de geração de espécies reativas de oxigênio (ROS, do inglês Reactive Oxygen Species) por meio da NADPH Oxidase (NOX) na presença do cofator NADPH. A NOX é um complexo proteico multimérico composto pelas subunidades gp91 e p22 (expressos constitutivamente na membrana de neutrófilos em repouso e, denominada de citocromo $b_{558}$ ) e pelas subunidades citoplasmáticas p47, p67, Rac e p40 (Figura 8) que só interagem após a ativação do neutrófilo $(117,118)$. A NOX pode estar presente na membrana citoplasmática $(5 \%)$, membrana do fagossomo ou membrana das vesículas (95\%) (117). Após a produção de $\mathrm{ROS}\left(\mathrm{O}_{2}{ }^{-}\right)$dentro dos fagócitos (ROS fagocítico - phROS), a enzima superóxido dismutase (SOD) pode 
atuar formando peróxidos de hidrogênio e, posteriormente, por meio da ação da mieloperoxidase (MPO), uma enzima presente nos fagolisossomos, o peróxido de hidrogênio pode interagir com íons cloro formando o ácido hipocloroso ( $\mathrm{HClO})$ ou Hipoclorito ( $\left.\mathrm{ClO}^{-}\right)$que apresenta alta atividade microbicida $(118,119)$. A presença NOX na membrana citoplasmática dos neutrófilos, é importante para ocorra formação de ROS extracelular (ecROS - Figura 9) que irá atuar sobre patógenos grandes demais para serem fagocitados, como por exemplo hifas de Aspergillus fulmigatus $(117,120)$.

Outro importante mecanismo utilizado pelos neutrófilos na eliminação de microrganismos fagocitados é a síntese de NO. Estímulos de citocinas (IL-1, TNF- $\alpha$ e IFN- $y$ ) ou produtos microbianos (LPS) levam a síntese de óxido nítrico sintase induzida (iNOS) que atua na conversão de L-arginina em L-citrulina na presença de NADPH liberando NO (L-Arginine $+\mathrm{O}_{2}+\mathrm{NADPH} \rightarrow \mathrm{NO}+\mathrm{L}$-Citrulline + $\mathrm{NADP}^{+}+\mathrm{H}_{2} \mathrm{O}$ ) (121). Uma vez liberado, o $\mathrm{NO}$ pode interagir rapidamente com $\mathrm{O}_{2}^{-}$(proveniente do Burst oxidativo) formando radicais peroxinitrito ( $\mathrm{NO}+\mathrm{O}_{2}^{-} \rightarrow$ $\mathrm{NO}_{3}{ }^{-}$) que apresentam grande potencial de oxidação e microbicidas (122-124). Inúmeros trabalhos na literatura mostram a importância dos neutrófilos na fagocitose e eliminação de diversos patógenos, como a Leptospira (125), Borrelia burgdorferi (126), Paracoccidioides brasiliensis (127), Candida albicans $(128,129)$ e Aspergillus fumigatus $(107,130,131)$. Entretanto, poucos trabalhos demonstram sua importância no combate aos fungos causadores da cromoblastomicose (93).

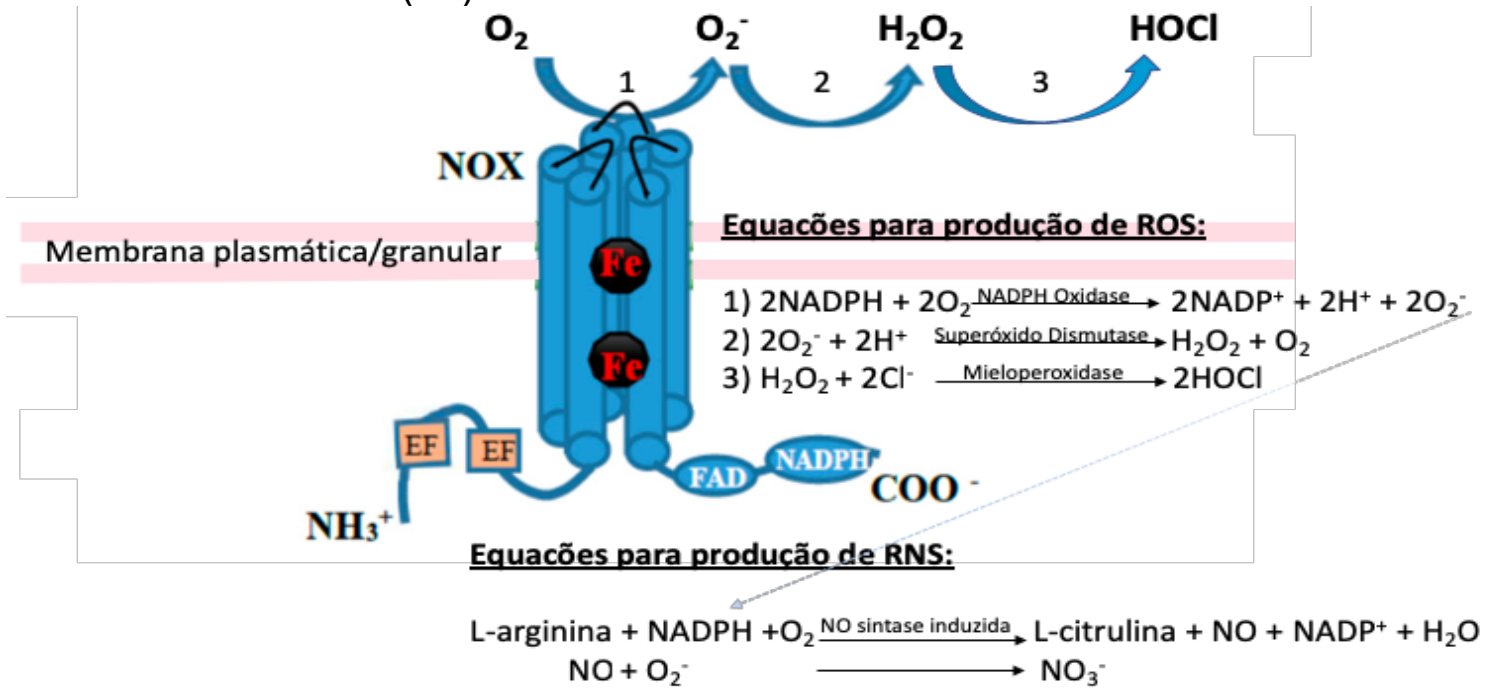

Figura 9 Etapas da formação de espécies reativas de oxigênio (ROS) e de nitrogênio (RNS): Após ativação dos neutrófilos, o complexo da NOX é montado e, na presença de NADPH, o oxigênio molecular se transforma em superóxido $\left(\mathrm{O}_{2}{ }^{-}\right)$. Na presença da enzima $\mathrm{SOD}$ e do íon $\mathrm{H}^{+}$da reação ocorre liberando peróxido de hidrogênio $\left(\mathrm{H}_{2} \mathrm{O}_{2}\right)$ e oxigênio. $\mathrm{O}$ peróxido de hidrogênio por sua vez pode interagir com íons de cloro $\left(\mathrm{Cl}^{-}\right)$na presença de 
enzima MPO formando o ácido hipocloroso. O superóxido gerado pela NOX, pode também ser utilizado na geração de RNS. A L-arginina, na presença de NADPH e oxigênio e da enzima NO sintase induzida (iNOS) gera L-citrulina, NO e NADP+ e água. O óxido nítrico então, reage com o superóxido gerando o nitrato, composto com alta atividade microbicida (Adaptado de (132)).

\subsubsection{Liberação de grânulos:}

Em 1960, os pesquisadores Cohn e Hirsch identificaram enzimas microbicidas presentes nos grânulos dos neutrófilos (133) e em 1964, ZuckerFranklin e Hirsch observaram que estes grânulos eram liberados nos fagossomos, ajudando na eliminação dos patógenos fagocitados (Figura 10) (134).
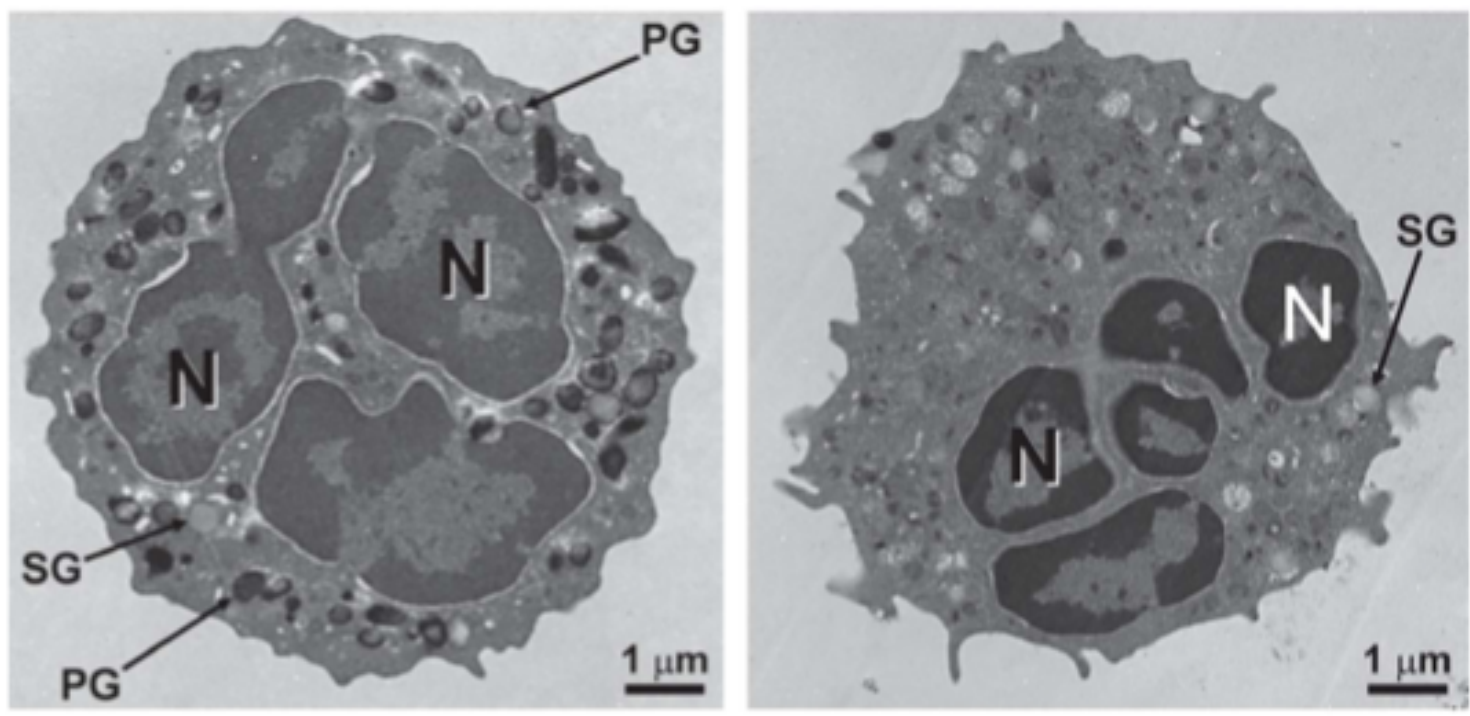

Figura 10 Processo de degranulação de neutrófilo: Em imagem de microscopia eletrônica de transmissão observamos à esquerda o neutrófilo não estimulado, onde podemos observar diversos grânulos primários (PG), com presença de MPO, e grânulos secundários (SG). (Direita) Após estimulo, observamos uma diminuição dos grânulos intracelular, devido ao processo de degranulação dos neutrófilos (imagem retirada de (135)).

Ao longo dos últimos anos, diversos grupos de pesquisa vêm caracterizando os grânulos presentes em neutrófilos e identificando seus componentes para melhor entender seu papel na eliminação dos patógenos. Até o momento, foram descritos 4 tipos de grânulos que podem ser divididos em 3 grandes grupos: 1) Grânulos positivos para mieloperoxidase (grânulos primários/azurofílicos); 2) Grânulos negativos para mieloperoxidase (secundários/específicos e grânulos terciários/gelatinase); 3) Vesículas secretórias. A composição destes grânulos está descrita na tabela $2(136,137)$. 
Tabela 2: Composição dos grânulos presentes nos neutrófilos

Grânulos

Primários/Azurofilicos

Secundários/Específicos

Terciário/Gelatinase

Vesículas Secretórias
Componentes

intravesicular

CD63, CD68

MPO, Lisozimas,

defensinas, catepsinas,

elastase e proteinase 3

Lactoferrina, Lisozimas,

colagenase, PTX3 e baixa

expressão de gelatinase

Alta expressão de

gelatinase, Lisozimas e

arginase 1

Proteínas plasmáticas

(Albumina), DAF, CD10 e

CD13

(Tabela adaptada de (138))

Os grânulos secundários apresentam a maior quantidade de citocromo b558 e, portanto, são importantes para a realização do burst oxidativo. Esses grânulos, juntamente com os grânulos primários (que contém MPO) podem se fundir ao fagossomo, gerando ROS intracelular (ROS fagocítico - phROS) e, posteriormente, o ácido hipocloroso, conforme descrito do item 1.5.1.1. Porém, a geração de ROS intracelular também pode ocorrer independente do fagossomo (ROS não-fagocítico - nphROS). Neste caso, os grânulos primários e os grânulos secundários, ou terciários, podem se fundir gerando o nphROS. Outro mecanismo pelo qual o nphROS pode ser gerado é por meio da difusão do $\mathrm{O}_{2}^{-}$gerado nos grânulos secundários/terciários, até os grânulos primários, que na presença da MPO conseguiria formar o ácido hipocloroso (117). Os componentes presentes nos grânulos primários e secundários, também podem ser liberados para o meio extracelular. Está degranulação ocorre, principalmente, quando suas vesículas se fundem ao fagossomo ainda em formação, ou seja, enquanto a membrana citoplasmática sofre invaginação para fagocitar o microrganismo e não está totalmente "selada" podendo assim, atingir o meio extracelular (139). A degranulação das vesículas secretórias e dos grânulos de gelatinase ocorre numa ativação moderada dos neutrófilos e atuam, 
respectivamente, aumentando a expressão de $\beta_{2}$-integrina (CD18) - que facilita sua migração para o foco inflamatório - e na degradação de colágeno tipo IV presente em grandes quantidades nos tecidos intersticiais e, portanto, têm grande importância na migração dos neutrófilos (136).

\subsubsection{Neutrophil Extracelullar Traps - NETs:}

Esta é a função mais recente descrita nos neutrófilos. Em 2004, Brinkmann e colaboradores (140) observaram que neutrófilos ativados com IL-8, phorbol myristate acetate (PMA), ou LPS liberavam fibras para o meio extracelular, e denominaram essas estruturas de Neutrophil Extracelullar Traps (NETs). Naquele momento, a liberação das NETs foi descrita como um processo dependente de NADPH oxidase e, portanto, da produção de ROS. Utilizando a microscopia eletrônica de varredura eles observaram que essas estruturas apresentavam entre 15-17 $\mathrm{nm}$ de diâmetro e estruturas globulares de aproximadamente $25 \mathrm{~nm}$ (Figura 11).
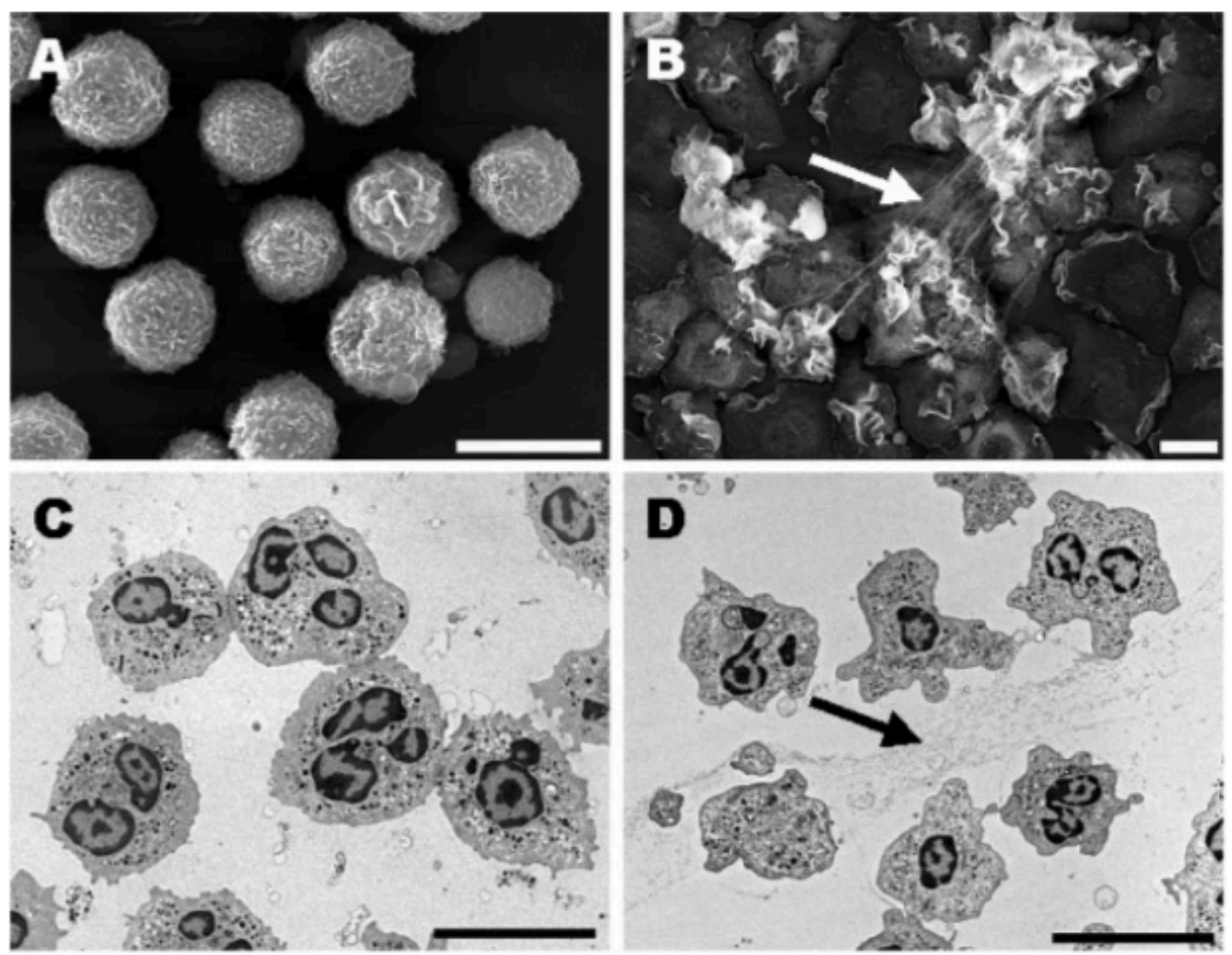

Figura 11 Liberação de NETs por neutrófilos humanos: Imagens de microscopia de varredura mostram os neutrófilos não estimulados como células arredondadas (a). Após estimulo com PMA, as células sofrem achatamento, com protrusão de sua membrana plasmática e liberação de filamentos de DNA, conhecidos como NETs (b). Imagens de microscopia eletrônica de transmissão mostra o núcleo multilobulado dos neutrófilos não estimulados (c). Após estímulo com IL-8, observamos a decondensação nuclear bem como o rompimento na membrana nuclear e liberação de seu conteúdo ao meio extracelular (d-seta) (140). 
Por meio da técnica de imunofluorescência, observou-se que as NETs eram compostas pelas seguintes proteínas: Elastase, catepsina G, mieloperoxidase (grânulos azurofílicos); Lactoferritina (grânulos secundários) e gelatinase (grânulos terciários); e Histonas ( $\mathrm{H} 1, \mathrm{H} 2 \mathrm{~A}-\mathrm{B}, \mathrm{H} 3 \mathrm{e} \mathrm{H} 4)$, que apresentam atividades microbicidas em baixas concentrações. Naquele momento os autores descreveram a morte celular envolvida na liberação das NETs como sendo distinta da apoptose (por ser independente de caspases) e da necrose (devido a diferentes características morfológicas e por ser dependente de NADPH oxidase e, portanto, de produção de ROS). Apenas em 2007, o termo NETosis foi descrito para caracterizar a morte celular responsável pela liberação das NETs (141). Entretanto, neste mesmo ano Clark e colaboradores demonstraram que células intactas também eram capazes de liberar NETs, sugerindo um mecanismo alternativo a NETosis descrita até o momento (142). Posteriormente, dois trabalhos demonstraram que os neutrófilos eram capazes de liberar NETs independente de morte celular. Esta liberação pode ocorrer via secreção de vesículas contendo DNA mitochondrial (143) ou nuclear (144). Posteriormente, verificou-se que a NETosis pode ocorrer de forma independente da produção de ROS proveniente da NOX (145). Deste modo, diferentes mecanismos podem levar a de liberação de NETs pelos neutrófilos, podendo ser classificada em relação à morte celular: NETosis precoce ou vital (independente de morte celular) ou NETosis clássica, descrita por Brinkmann (tardia e dependente de morte celular) $(146,147)$. Outra forma de classificarmos os diferentes tipos de NETosis seria quanto à dependência da produção de ROS pela NOX: NETosis dependente de NOX ou NETosis independente de NOX. Até o momento foram descritas algumas particularidades que distinguem a NETosis vital da NETosis Clássica, são elas: 1) O tempo e a natureza do estímulo: NETosis clássica ocorre normalmente após 3 a 4 horas de estímulo enquanto a NETosis vital ocorre em menos de 1 hora; 2) Capacidade funcional dos neutrófilos: Neutrófilos que sofrem NETosis clássica têm sua membrana nuclear e celular rompida, gerando a morte dessas células, enquanto que neutrófilos que sofrem NETosis vital apresentam sua membrana celular intacta, mantendo sua capacidade fagocítica e de quimioatração intactas; 3) O mecanismo envolvido na liberação das NETs: NETosis clássica é uma atividade dependente da ativação de raf-MEK-ERK, elastase, MPO, NOX e ROS que levam à 
decondensação da cromatina que interagem com os grânulos proteicos e são liberados por meio de ruptura da membrana plasmática, enquanto que NETosis vital ocorre por tráfego vesicular de DNA do núcleo (ou mitocondrial) para o meio extracelular. As moléculas ativadas na NETosis vital ainda não foram identificadas (147). Se dividirmos em relação à ativação da NOX, observamos que a liberação de NETs dependente de NOX é um processo tardio, ocorrendo em torno de 3 a 4 horas após estímulo, enquanto que a via NOX independente se inicia após 30 minutos de estímulo. Em relação aos processos moleculares, a NETs dependente de NOX é um mecanismo dependente da ativação de ERK e independente de ativação de Akt, de citrulinação de histonas via Peptidylarginine deiminases 4 (PAD 4) e da produção de ROS mitocondrial, enquanto a via independente de NOX é dependente de Akt, de PAD4 e da produção de ROS mitocondrial mas independente de ERK (145).

Inúmeros trabalhos demonstram a importância da liberação das NETs sobre diversos patógenos $(128,140,146,148)$. Entretanto, mecanismos de evasão às NETs já foram descritos em bactérias $S$. pneumoniae, S. pyogenes e S. aureus, as quais são capazes de liberar DNases para degradar e escapar da morte pelas NETs (149). Em relação às infecções fúngicas, sabe-se que os neutrófilos são capazes de liberar NETs após estímulo por Candida albicans, Aspergillus fumigatus, Paracoccidioides brasiliensis and Cryptococcus gatti. $\mathrm{O}$ mecanismo pelo qual os neutrófilos liberam NETs sobre a $C$. albicans ainda não está bem elucidado, visto que a dependência da produção de ROS na sua liberação ainda é controverso $(150,151)$. Verificou-se que os receptores CR3 reconhecem as $\beta$-glicanas de $C$. albicans e - na presença de fibronectina estimulam a liberação das NETs sobre as formas de leveduras e pseudohifas deste fungo (151). Entretanto, os receptores Dectina-1 não influenciam a liberação de NETs sobre a C. albicans (151). Achados similares foram vistos com o fungo $A$. fumigatus, o qual estimula a liberação de NETs dependente de NOX e receptor CR3, mas independente do receptor Dectina-1 (107). Entretanto, verificou-se que as NETs não apresentam atividade fungicida, mas apenas fungiostática sobre 0 A. fumigatus $(90,107,131)$ sendo 0 Galactosaminogalactan (GAG) (152) e a proteína de membrana RodA (153), dois importantes fatores de virulência na proteção deste fungo às NETs. Outro fungo capaz de estimular a liberação de NETs é o C. gatti. Entretanto, a função 
fungicida das NETs sobre este fungo não está bem estabelecida (154). Embora o C. gatti consiga estimular a liberação de NETs, outra espécie de Cryptococcus, o C. neoformans, apresenta fatores de virulência que inibem a liberação deste composto pelos neutrófilos. Os polissacarídeos capsulares do C. neoformans conseguem inibir a liberação de NETs mesmo em neutrófilos previamente estimulados e ativados com PMA. Entretanto, quando utilizado uma cepa mutante acapsulada, os neutrófilos foram capazes de liberar NETs de maneira dependente de ROS e da enzima PAD-4, tendo elas apresentado função fungiostática sobre este fungo (154). Outro trabalho que demonstra a importância dos componentes de membrana na ativação e liberação das NETs foi realizado com o $P$. brasiliensis. Nele, os pesquisadores verificaram que os conídios estimulam NETs independente de NOX, enquanto as leveduras estimulam NETs dependente de NOX (155). Outro trabalho demonstrou que, a importância dos receptores de Dectina-1 (156), mas não dos receptores TLR-2 e TLR-4 (157) na liberação das NETs. Entretanto, as NETs apresentam atividade fungiostática, mas não fungicida sobre o $P$. brasiliensis.

Embora as NETs tenham sido descrita há mais de 10 anos, ainda são necessários estudos para entender os mecanismos pelos quais os neutrófilos são ativados e estimulados a liberarem essas estruturas.

\subsubsection{Subpopulações de neutrófilos}

Embora por muitos anos o neutrófilo tenha sido caracterizado como uma célula totalmente diferenciada e homogênea, atualmente vem crescendo o número de trabalhos demonstrando a presença de diferentes subpopulações desta célula. Um dos primeiros trabalhos que demonstra a existência dessas subpopulações foi publicado na década de 70 , onde os pesquisadores verificaram 2 subpopulações de neutrófilos baseado na sua densidade celular (158). Mais tarde, estudando a resposta imune frente a tumores sólidos, diversos pesquisadores observaram a presença de neutrófilos no microambiente tumoral, sugerindo que estas células apresentavam função citolítica e antitumoral (159162). No final da década de 80 e início da década de 90 , foram publicados os primeiros relatos de células mieloides supressoras observadas em pacientes com câncer (163-165). Em 1995, Pekarek e colaboradores verificaram uma diminuição do tamanho do tumor, bem como da sua capacidade de metástase 
em animais neutropênicos (animais tratados com anti-Gr1), sugerindo que seriam os neutrófilos as células mieloides que estariam atuando suprimindo a resposta imune e, portanto, ajudando na proliferação tumoral (159). Somente 14 anos após a observação de Pekarek, foi sugerido a presença de subpopulações N1 e N2 de neutrófilos associados aos tumores (TANs, do inglês TumorAssociated Neutrophils) (166). Fridlender e colaboradores, ao estudar o papel do TGF- $\beta$ no microambiente tumoral, verificaram que ao bloquear a produção de TGF- $\beta$ havia um aumento no influxo de neutrófilos (CD11 $\left.\mathrm{b}^{+} / \mathrm{Ly} 6 \mathrm{G}^{+}\right)$capazes de produzir citocinas pró-inflamatórias, estimular a ativação de linfócitos T CD8 ${ }^{+} \mathrm{e}$ macrófagos e apresentar função citotóxica frente ao tumor. Ao analisar as TANs na presença de TGF- $\beta$, os pesquisadores observaram um aumento na produção de citocinas anti-inflamatórias, juntamente com uma diminuição da ativação e dos linfócitos T CD8 ${ }^{+}$e de sua função citotóxica frente ao tumor. Deste modo, os pesquisadores sugeriram que o microambiente tumoral continha subpopulações N1 e N2 de TANs, sendo que a população N1 apresentava ações inflamatórias e antitumorais enquanto a população N2 apresentava ações anti-inflamatórias e pró-tumorais (166).

No início do século $X X$, uma população de célula mieloide imatura, com capacidade de suprimir o sistema imune, foi identificada também no microambiente tumoral. Durante anos esta população recebeu diferentes nomes pelos grupos de pesquisas ao redor do mundo, até que, em 2007, Gabrilovic e colaboradores denominaram estas células de MDSC (do inglês Myeloid-Derived Suppressor Cell) (167). Devido a dificuldades em caracterizar estas células, recentemente, foi publicado um artigo de revisão com o intuito de padronizar a nomenclatura, bem como definir as funções específicas que caracterizam as MDSCs (168). Deste modo, essas células foram subdivididas em 2 populações: monocítica (Mo)-MDSCs e granulocítica (G)-MDSCs ou também chamada de polimorfonuclear (PMN)-MDSCs. Entretanto, ainda não há um consenso se as G-MDSCs/PMN-MDSCs são uma população celular específica ou se são uma subpopulação dos neutrófilos ou até mesmo a subpopulação N2 de TANs, descrita por Fridlender em 2009. Há trabalhos que defendem que as MDSCs são células mieloides imaturas, enquanto os TANs-N2 são células maduras e, portanto, são duas populações diferentes (169-172). No entanto, diversos grupos 
de pesquisa $(167,173,174)$, dentre eles o próprio grupo do pesquisador Gabrilovic (o qual sugeriu o termo MDSCs pela primeira vez) salienta que a distinção entre TAN e PMN-MDSC é atualmente impossível, uma vez que estas células apresentam o mesmo fenótipo. As características das PMN-MDSCs (N2) estão melhores descritas na Tabela abaixo (Tabela 3).

Tabela 3: Marcadores de superfície e ensaios funcionais dos neutrófilos e MDSCs

Nomenclatura Marcadores de Superfície Ensaios funcionais

Neutrófilo $\quad$ CD11b $\quad / L^{+} 6 G^{+}$

convencional/N1

Atividade citolítica e killing

Mo-MDSCs

CD11b+/Ly6C hi/Ly6G $^{-}$

de patógenos

Inibição de proliferação de

células $\mathrm{T}$

PMN-MDSC/N2

CD11b+/Ly6C ${ }^{\text {lo }} /$ Ly6G $^{+}$

Inibição de proliferação de

células $\mathrm{T}$

Embora a subpopulação N2/PMN-MDSC tenha sido descrita em modelos de tumor, alguns trabalhos relacionados a doenças infecciosas vêm demonstrando a presença destas células atuando na inibição do sistema imune adaptativo e favorecendo a disseminação e cronicidade dessas doenças. Em 2007, foi publicado o primeiro trabalho que descreve a presença de células imaturas CD11 $\mathrm{b}^{+} / \mathrm{Gr} 1^{+}$em modelo de infecção (175). Os autores verificaram que animais sépticos apresentavam um aumento dessas células, as quais atuavam suprimindo as células T. Posteriormente, outros trabalhos verificaram a presença dessas células em infecções bacteriana, viral, parasitária e fúngica (para revisão do assunto vide (176)). Embora o primeiro trabalho que descreva as MDSCs em modelo de infecção tenha sido publicado apenas em 2007, no ano de 2003, o grupo do Dr. Casadevall verificou que animais neutropênicos (neutropenia causada por administração de anticorpo anti-Gr1) apresentavam alteração no perfil de citocinas e susceptibilidade à infecção por Cryptococcus (177). Naquele momento, o conceito de MDSCs e dos neutrófilos N2 ainda não estava definido e, portanto, os autores apenas especularam que os neutrófilos atuavam modulando a resposta imune na criptococose, sendo deletério ao hospedeiro 
infectado. Entretanto, atualmente acredita-se que o Cryptococcus também atue aumentando e estimulando a produção de células MDSCs garantindo, portanto, a cronicidade da doença. Embora a função mais estudada e discutida das MDSCs/N2 atualmente seja sua capacidade em inibir a proliferação e ativação de linfócitos $T$, trabalhos demonstram que estas células também inibem a maturação de DCs (178-181) e a ativação de células Natural Killer (NK) (178, 182, 183). Em 2015, Mueller-Leisse e colaboradores verificaram que as PMNMDSCs eram capaz de inibir a ativação de NK frente a infecção por $A$. fumigatus (182)

O número de trabalhos publicados sobre as células MDSCs em modelos de infecção vem aumentando conforme o conceito de MDSC se torna mais sólido. Porém, mais estudos são necessários para melhor entendermos e classificarmos essas células, ou como um grupo de células imaturas provenientes de precursores mieloides ou como uma subpopulação de neutrófilos que apresenta uma função antagônica à função classicamente descrita e estudada até o momento. 


\section{HIPÓTESE}

Sabendo da importância dos neutrófilos no combate às infecções fúngicas, formulamos a hipótese de que estas células são essenciais no combate a cromoblastomicose, apresentando diferentes funções efetoras na eliminação dos conídios e hifas do F. pedrosoi, devido à diferença no tamanho e na composição dos componentes de membrana, sendo os receptores TLR-2 e TLR4 importantes no reconhecimento e eliminação deste fungo.

\section{OBJETIVOS}

\subsection{Objetivo geral}

Investigar a importância dos receptores TLR-2 e TLR-4 nas funções efetoras dos neutrófilos em infecções por conídios e hifas de $F$. pedrosoi, bem como a importância dos neutrófilos e destes receptores na contenção e resolução da infecção por $F$. pedrosoi em camundongos.

\subsection{Objetivos específicos}

Utilizando animais C57BI/6 WT, TLR-2KO e TLR-4KO nós avaliamos:

\section{In vitro}

- O índice fagocítico, quimiotaxia, produção de ROS e a formação de NETs em infecções por conídios e hifas de F. pedrosoi;

\section{In vivo}

- O papel desses receptores em modelo murino de cromoblastomicose causado por conídios de F. pedrosoi, analisando a carga fúngicas e perfil celular;

- A importância dos neutrófilos murinos no combate à cromoblastomicose causado por conídios de F. pedrosoi, por meio da depleção destas células pelo tratamento dos animais com anticorpo anti-Gr1. 


\section{MATERIAIS E MÉTODOS}

\subsection{Cultivo do fungo}

Para a realização dos experimentos abaixo, utilizamos a cepa $F$. pedrosoi. O cultivo do fungo foi realizado em meio ágar Sabouraud Dextrose (MERCK, Alemanha), mantido em estufa a $30^{\circ} \mathrm{C}$, com repiques semanais. Com a finalidade de aumentar a virulência fúngica, previamente aos ensaios de infecção, à cepa foi inoculada intraperitonealmente (i.p.) nos camundongos e recuperadas 21 dias após a infecção.

\subsubsection{Obtenção de inóculo enriquecido de conídios ou hifas}

O cultivo foi realizado em meio caldo batata (Becton Dickinson - BD) por 5 dias a $30^{\circ} \mathrm{C}$ sob agitação (shaker, 200rpm) para enriquecimento do inóculo. Posteriormente, mantivemos o frasco em repouso por 15 minutos para sedimentação espontânea das hifas e, recolhemos e transferimos o sobrenadante (rico em conídios) para outro um tubo cônico, passando-o por "cell strainer" de $40 \mu \mathrm{m}$ para retenção das hifas remanescentes. Os conídios obtidos e o material retido no cell strainer (hifas) foram centrifugados 3 vezes (8000 rpm por 5 minutos) com solução salina tamponada estéril (PBS - $137 \mathrm{mM} \mathrm{NaCl}$; 2,7

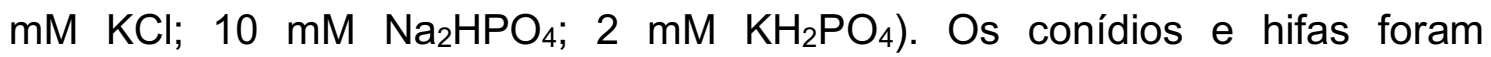
quantificados em câmara de Neubauer e ajustado de acordo com o ensaio.

\subsection{Animais}

Utilizamos camundongos C57BI/6 machos com 8-12 semanas de idade, mantidos em condições "livres de patógenos" (SPF, do inglês specific pathogen free). Estes animais foram fornecidos pelo Biotério de Camundongos Isogênicos, da Faculdade de Ciências Farmacêuticas da Universidade de São Paulo (USP). Este projeto foi aprovado pelo Comitê de Ética do Instituto de Ciências Biomédicas da USP sob protocolo número 074/2014 e da Faculdade de Ciências Farmacêuticas da USP sob protocolo de número 474.

\subsection{Obtenção de neutrófilos murinos da medula óssea:}

Diferentemente dos Humanos - que apresentam em torno de $70 \%$ de neutrófilos no sangue periférico - os murinos apresentam cerca de 10 a $20 \%$ 
destas células no sangue, sendo os linfócitos os leucócitos circulantes mais abundantes nesses animais. Deste modo, decidimos utilizar a medula óssea como fonte de neutrófilos, uma vez que uma grande quantidade madura destas células está presente neste local. Os neutrófilos murinos foram obtidos da medula óssea de animais C57BI/6 WT, TLR-2KO e TLR-4KO e purificados por seleção magnética positiva utilizando o kit Anti-Ly-6G Microbeads UltraPure Miltenyi Biotec, Cologne, Germany, conforme instruções do fornecedor ou por gradiente de Ficoll. Resumidamente, os animais foram eutanasiados com sobredose de anestésico (conforme procedimento pré autorizado pelo CEUA) e os fêmures e tíbias foram retirados e suas células foram coletadas utilizando PBS com $2 \%$ de soro fetal bovino (SFB). Para purificação dos neutrófilos utilizando gradiente de Ficoll, nós realizamos a lise de hemácias com água destilada gelada e, posteriormente ressuspendemos o pellet em $1 \mathrm{~mL}$ de PBS 1x e colocamos sobre $3 \mathrm{~mL}$ de Ficoll 1077 e Ficoll 1119. As amostras foram então centrifugadas por 30 minutos, a $900 \times \mathrm{g}$ e $20^{\circ} \mathrm{C}$. Para evitar distúrbios na camada de ficoll e interferência na separação das células, a centrifugação foi ajustada para ter sua aceleração diminuída (accel. 5) e seu freio reduzido (break $0)$. Após centrifugação, as células mononucleadas foram coletadas acima da camada de Ficoll 1077 (entre o PBS e ficoll) e desprezadas, enquanto os polimorfonucleares foram coletados entre a camada de Ficoll 1077 e Ficoll 1119. Após lavagens com PBS $1 \mathrm{x}$, as células foram ressuspendidas em $1 \mathrm{~mL}$ de PBS 1x e uma alíquota foi retirada para contagem e verificação da viabilidade celular em câmara de Neubauer e outra alíquota foi utilizada para verificarmos a pureza das células por citometria de fluxo. A viabilidade celular foi observada utilizando azul de tripan, e os neutrófilos obtidos tanto por separação por beads quanto pelo método do Ficoll apresentaram viabilidade maior que 95\% (dados não mostrados). Para verificarmos a pureza das amostras, as células foram incubadas com os anticorpos anti-CD11b (e-bioscience diluído 1:100) e antiLy6G (e-bioscience diluído 1:100) em PBS1x contendo 2\% de albumina de soro bovino (BSA) a $4^{\circ} \mathrm{C}$ por 30 minutos. Após lavagem em PBS $1 \mathrm{x}$, as células foram adquiridas no citômetro FACSCanto II (BD Biosciences) utilizando o software FACSDIVA (BD Biosciences), e os resultados foram analisadas no software FLOWJO 8.7 (Tree Star, San Carlo, CA, EUA). 


\subsection{Ensaio de atividade fungicida dos neutrófilos}

Após obtenção das hifas e conídios de $F$. pedrosoi (item 3.1.1) e dos neutrófilos murinos (item 3.3 ), incubamos $2 \times 10^{5}$ conídios ou hifas do fungo com $1 \times 10^{5}$ neutrófilos (multiplicity of infection - MOI 2:1) por $2 \mathrm{~h}$ a $37^{\circ} \mathrm{C}$ sob leve agitação. Após este período, realizamos a diluição do inóculo (1:50) em água destilada estéril para garantirmos a lise dos neutrófilos (2 minutos). As amostras $(100 \mu \mathrm{L})$ foram plaqueadas em ágar Sabouraud e cultivadas em estufa a $30^{\circ} \mathrm{C}$ por 5 a 7 dias para posterior contagem das unidades formadoras de colônias (CFU). Como controle positivo (100\% de sobrevivência) conídios e hifas foram incubados na ausência de neutrófilos. Após diluição em água destilada (1:50) o fungo foi plaqueado normalmente e a contagem do CFU foi ajustada para $100 \%$ de sobrevivência. É importante salientar que neste ensaio as amostras não foram centrifugadas a fim de evitar a perda do fungo nas lavagens o que poderia resultar falsos dados sobre a capacidade fungicida dos neutrófilos.

\subsubsection{Morte por fagocitose ou liberação de NETs}

Para verificarmos a importância da fagocitose no killing fúngico, préincubamos as células (30 minutos) na presença de de cytochalasin $D(5 \mu \mathrm{g} / \mathrm{mL})$, pois esta é uma droga inibidora dos filamentos da actina e miosina e, portanto, é comumente utilizada para bloquear a fagocitose nas células (184-187). A importância das NETs no killing de F. pedrosoi foi verificado utilizando DNAse (25 U/mL). Este método é comumente utilizado na literatura, pois atua degradando as NETs (filamentos de DNA) liberadas ao meio extracelular inibindo, portanto, qualquer ação fungicida ou fungiostática que este composto possa apresentar (107, 128, 188-190). Após incubação com Cytochalasina-D ou DNAse as células foram incubadas com as diferentes formas do fungo, conforme descrito no item 3.4 .

\subsection{Avaliação do stress oxidativo dos neutrófilos}

$\mathrm{O}$ stress oxidativo (liberação de $\mathrm{ROS}, \mathrm{H}_{2} \mathrm{O}_{2}, \mathrm{HOCl}$ ) é comumente associado ao killing de patógenos fagocitados. Para sua análise, utilizamos $\mathrm{O}$ reagente de luminol e a técnica do luminômetro. Utilizamos $1 \times 10^{5}$ células incubadas com $2 \times 10^{5}$ conídios ou hifas em placa de 96 poços branca (Costar 3917). Como controles, incubamos os neutrófilos com PBS (controle negativo) 
ou PMA (controle positivo). O reagente de luminol foi adicionado e a placa foi colocada para leitura (por aproximadamente 90 minutos) em equipamento de luminômetro. Para análise, utilizamos a área sob a curva para quantificar a stress oxidativo total da célula após 90 minutos de estímulo. Para confirmarmos a importância do stress oxidativo celular na eliminação do F. pedrosoi, realizamos também o ensaio de killing (conforme descrito no item 3.4) na presença de diferentes concentrações de Diphenyleneiodonium (DPI), importante inibidor da NADPH-oxidase.

\subsection{Ensaio de fagocitose}

Para determinarmos a importância dos receptores TLR-2 e TLR-4 na fagocitose de conídios de F. pedrosoi, realizamos ensaio de microscopia de imunofluorescência. Primeiramente, lamínulas redondas de $13 \mathrm{~mm} \times 13 \mathrm{~mm}$ foram lavadas e esterilizadas, e colocadas dentro do poço de placa de cultura de 24 poços. Adicionamos então Poli-L-lisina por 30 minutos, para ajudar na adesão celular. Após lavagem com PBS $1 \mathrm{x}$ estéril, adicionamos $1,5 \times 10^{5}$ neutrófilos e $3 \times 10^{5}$ conídios em meio RPMI sem soro (volume final de $500 \mu \mathrm{L}$ ). A placa foi centrifugada ( 1 min a $500 \times \mathrm{g}$ ) para facilitar a interação células/conídios e incubada em estufa à $37^{\circ} \mathrm{C}$ com $5 \% \mathrm{CO}_{2}$ por $2 \mathrm{hrs}$. Após término do período de incubação, realizamos a lavagens dos poços com PBS 1x, para retirada dos conídios não fagocitados e as células foram permeabilizadas com PBS contendo $0,1 \%$ de Tween 20 (PBS-T) por 15 minutos. Após lavagem, realizamos o bloqueio com PBS 5\% BSA por 30 minutos seguido de marcação do material genético com 4',6-diamidino-2-phenylindole (DAPI) ou Sytox Green por 45 minutos. Após lavagem as lamínulas foram retiradas dos poços e colocadas sobre $5 \mu \mathrm{L}$ de meio de montagem Vecta-Shield $\AA$ em lâminas próprias para microscopia. Para evitar secagem e para obtermos maior durabilidade das lâminas, utilizamos base de esmalte para vedação das lamínulas. As lâminas foram armazenadas a $4^{\circ} \mathrm{C}$ até momento da captura de imagens em microscópio de imunofluorescência. As imagens foram capturadas em campo claro e sobreposta com as imagens capturadas com filtro AF 488 (Exc/Emm 495/519 nm) ou DAPI (Exc/Em 364/454 nm). Para calcularmos o índice fagocítico, realizamos a contagem de no mínimo 100 células e dos respectivos conídios observados dentro das células e aplicamos a seguinte fórmula: 
Índice fagocítico $=($ número de conídios dentro das células $\times 100) /$ número total de células contadas.

Para análise estatística nós calculamos a razão do índice fagocítico, onde o índice fagocítico dos neutrófilos TLR-2KO e TLR-4KO foi dividido pelo índice fagocítico dos neutrófilo WT.

\subsection{Produção de NETs em infecções por F. pedrosoi}

A fim de verificarmos a capacidade de conídios e hifas de F. pedrosoi em estimular a liberação de NETs por neutrófilo murinos, realizamos ensaios utilizando a sonda de DNA, Sytox Green. Esta sonda é impermeável às células, e só irá emitir fluorescência apenas quando se ligar ao DNA de células que apresentarem danos em sua membrana plasmática. Os neutrófilos $\left(1 \times 10^{5}\right)$ foram previamente incubados com Sytox green $(5 \mu \mathrm{M})$ e semeados em placas de 96 poços (placa preta com fundo claro - Costar 3603) e incubadas por 10 minutos para decantação das células. Posteriormente, realizamos a leitura da fluorescência utilizando equipamento SpectraMAX M2 $₫$ da Molecular Probes para determinarmos a fluorescência basal. Posteriormente, adicionamos conídios ou hifas de F. pedrosoi (ou PBS no grupo controle). A leitura foi realizada a cada 30 minutos, até o ponto final de 180 minutos. Durante o experimento, a placa foi mantida em estufa a $37^{\circ} \mathrm{C}$ e $5 \% \mathrm{CO}_{2}$, sendo retirada apenas no momento das leituras. Outra técnica utilizada para visualização das NETs foi a microscopia de imunofluorescência. O ensaio foi realizado conforme descrito no item 3.6, entretanto hifas de $F$. pedrosoi foram utilizadas no lugar dos conídios.

\subsection{Análise da migração dos neutrófilos frente aos estímulos de conídios e hifas de F. pedrosoi}

O ensaio de quimiotaxia foi realizado por meio da análise do número de neutrófilos migrados à cavidade peritoneal após 3 horas de infecção com conídios ou hifas de F. pedrosoi (191). Primeiramente os animais WT, TLR-2KO e TLR-4KO foram infectados intraperitonealmente com $5 \times 10^{7}$ conídios ou $4 \times 10^{6}$ hifas de F. pedrosoi (volume fina de $200 \mu \mathrm{L}$ ). Como controle, os animais receberam uma injeção intraperitoneal de $200 \mu \mathrm{L}$ de PBS-1x. Após 3 horas os 
animais foram eutanasiados e as células migradas ao peritônio foram coletadas por meio de lavagem peritoneal com $5 \mathrm{~mL}$ de PBS-1x 0,5\% SFB e $2 \mathrm{mM}$ EDTA. Posteriormente nós centrifugamos o lavado peritoneal e ficamos as células por 30 minutos com 4\% de paraformaldeído (PFA). Após lavagem, as células foram ressuspendidas em PBS-1x e contadas em câmara de Neubauer. Uma alíquota foi usada para marcação com anticorpos anti-CD45, anti-CD11b e anti-Ly6G para análise da porcentagem de neutrófilos atraídos ao peritônio. Posteriormente o número total de neutrófilos migrados ao peritônio foi calculado levando e consideração o número total de células migradas e a porcentagem de neutrófilos detectados por citometria de fluxo.

\subsection{Infecção intraperitoneal de animais C57BI/6 WT, TLR2-KO e TLR4-KO com conídios de F. pedrosoi:}

Para confirmarmos a importância destes receptores na cromoblastomicose murina, realizamos infecções i.p. com $5 \times 10^{7}$ conídios de $F$. pedrosoi. Os animais foram sacrificados após 1 dia de infecção, uma vez que neste período aguda da infecção os neutrófilos são as principais células atraídas ao foco inflamatório.

\subsubsection{Análise da carga fúngica no baço e fígado e obtenção de sobrenadante e células dos órgãos:}

Após a retirada do baço e fígado dos animais os órgãos foram pesados e posteriormente macerados em 1,5 e 2,0 mL de PBS 1x, respectivamente. Uma alíquota de $100 \mu \mathrm{L}$ dos macerados foi utilizada para realização do ensaio de CFU em placa petri com meio ágar Sabouraud. As placas foram mantidas em estufa a $37^{\circ} \mathrm{C}$ por 5 a 7 dias para posterior contagem de CFU. O volume restante do macerado foi submetido à centrifugação de $500 \times \mathrm{x}$ por 5 minutos para obtenção do sobrenadante, que foi armazenado em freezer $-80^{\circ} \mathrm{C}$ para posterior análise de citocinas por ELISA (conforme descrito abaixo no item 3.9.2). Após coleta do sobrenadante, o pellet contendo as células foi submetido a lise de hemácia para contagem total dos leucócitos e posterior marcação e análise das populações celulares por citometria de fluxo (conforme descrito abaixo no item 3.9.3). Células do baço $\left(1 \times 10^{7}\right)$ dos animais infectados por 10 dias foram separadas para posterior análise de linfoproliferação (conforme descrito no item 3.11.1). 


\subsubsection{Dosagem de citocinas:}

Conforme descrito no item acima (item 3.9.1) utilizamos os sobrenadantes do macerado de baço e fígados para dosagem das seguintes citocinas: IL-4, IL6, IL-10, IL-12, IL-17, TNF- $\alpha$ e IFN-y. A dosagem das citocinas foi realizada conforme instruções do fabricante (R\&D system). No final, os valores obtidos foram então multiplicados pelo fator de diluição e seu valor final foi calculado em relação ao peso do órgão.

\subsubsection{Imunofenotipagem por citometria de fluxo:}

Após a obtenção das células (ver item 3.9.1), realizamos a marcação celular utilizando o Tabela descrito abaixo (Tabela 4):

Tabela 4: Marcadores utilizados para a Imunofenotipagem das células obtidas do baço e fígado de animais infectados

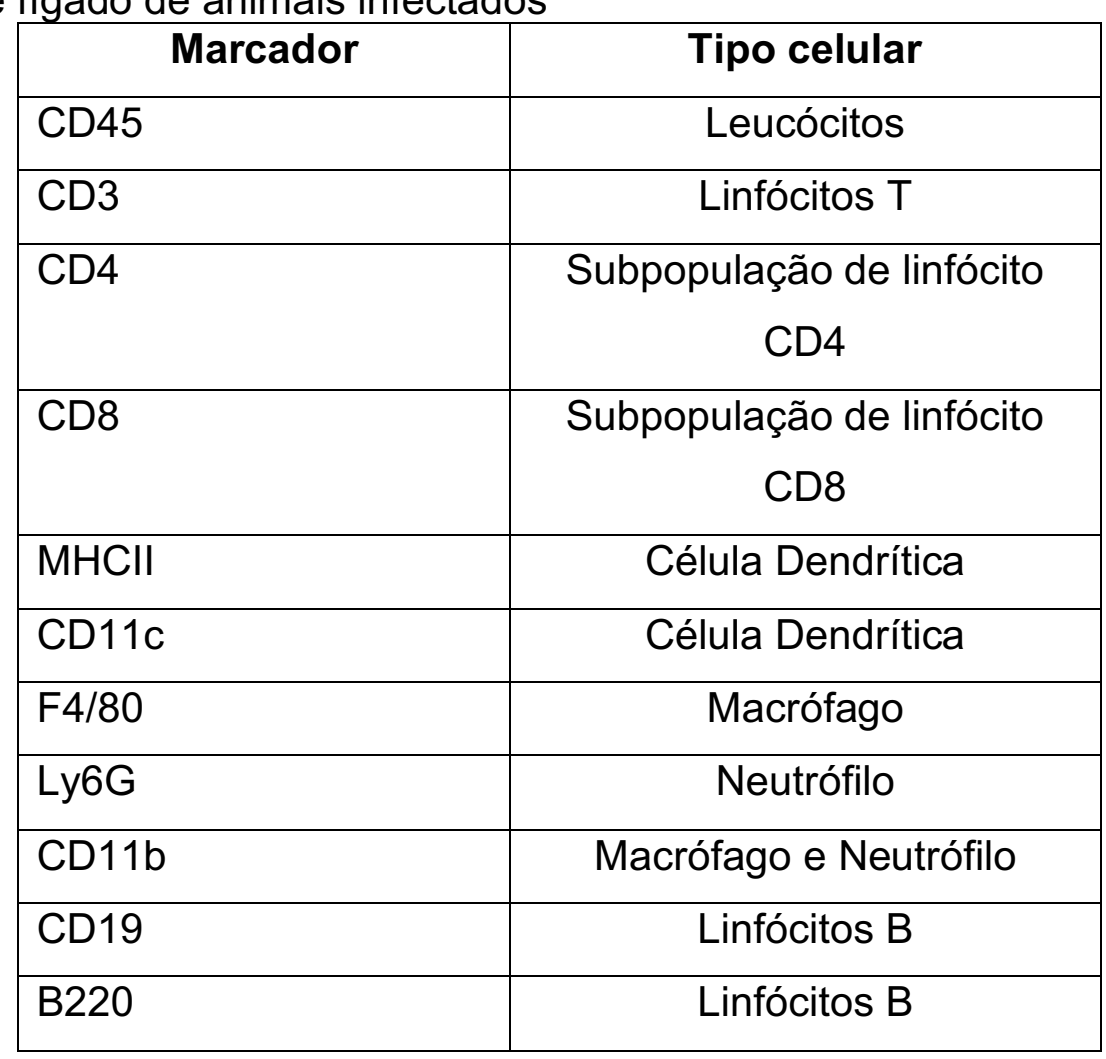

Para marcação utilizamos 4 mix de anticorpos, uma para marcação de linfócitos $\left(\mathrm{CD}^{2} 5^{+}, \mathrm{CD}^{+}, \mathrm{CD}^{+}\right.$e $\left.\mathrm{CD} 8^{+}\right)$, outro para marcação de células dendríticas $\left(\mathrm{CD}^{4} 5^{+}, \mathrm{CD} 11 \mathrm{C}^{+}, \mathrm{MHClI}^{+}\right.$e $\left.\mathrm{F} 4 / 80^{-}\right)$, uma para marcação de macrófagos (CD45 $\left.{ }^{+}, \mathrm{Cd} 11 \mathrm{~b}^{+}, \mathrm{F} 4-80^{+}\right)$e neutrófilos $\left(\mathrm{CD} 45^{+}, \mathrm{Cd} 11 \mathrm{~b}^{+}\right.$e $\left.\mathrm{Ly}_{6 \mathrm{G}}\right)$ e por fim para marcação de linfócitos $B\left(C D 45^{+}, C D 19^{+}\right.$e B220 $)$. Após contagem 
em câmara de Neubauer, $1 \times 10^{6}$ células foram utilizadas para marcação com os anticorpos acima descritos por 30 minutos a $4^{\circ} \mathrm{C}$ sob proteção da luz. As células foram lavadas 2x com PBS 2\% SFB e ressuspendidas em $150 \mu \mathrm{L}$ da mesma solução para aquisição das amostras em FACS canto II (BD Bioscience). Caso a aquisição das amostras não fosse realizada em até 1 hora, as mesmas foram fixadas com PFA 4\% por 15 minutos. Após lavagens as células foram mantidas em PBS $2 \%$ SFB a $4^{\circ} \mathrm{C}$ sob proteção da luz até o momento da aquisição das amostras.

\subsection{Cultivo do hibridoma RB6-8C5 para obtenção de anticorpos anti-Gr1:}

A produção de anticorpos anti-Gr1 foi necessária para geração da neutropenia transiente em animais C57BI/6 WT. Primeiramente realizamos o descongelamento do hibridoma em meio RPMI com 20\% SFB (R20). As células foram ressuspendidas em $5 \mathrm{~mL}$ de $\mathrm{R} 20$ e centrifugadas para retirada do meio de congelamento contendo DMSO. Após lavagem, as células foram cultivadas em meio RPMI com 10\% SFB (R10) por 1 semana para adaptação das células e retirada de debris e células mortas. Após este período, realizamos o repique em meio RPMI contendo $10 \%$ de soro IgG low (R10-Low). Cultivamos aproximadamente $1 \times 10^{7}$ células em $100 \mathrm{~mL}$ de R10-Low sistema de biorreator (CELLine - Argos Technologies) por 5 dias. Após este período, o seu sobrenadante contendo anticorpos anti-Gr1 foi recuperado e congelado com 0,01\% de azida sódica até o momento de sua purificação.

A purificação do anticorpo anti-Gr1 foi realizada em coluna de proteína $G$ (Hitrap $5 \mathrm{~mL}$ - GE healthcare) conforme instruções do fabricante. Resumidamente, deixamos o sobrenadante passando pela coluna de proteína $G$ durante a noite, a $4^{\circ} \mathrm{C}$. Após diversas lavagens da coluna em tampão fosfato ( $\mathrm{pH} 7)$, um choque de $\mathrm{pH}$ utilizando glicina $(\mathrm{pH} 2,7)$ foi realizado e seu eluato foi recolhido em tampão Tris- $\mathrm{HCl}(\mathrm{pH}$ 9) para neutralização do $\mathrm{pH}$, evitando assim a degradação proteica. Estes processos foram realizados por 3 vezes, para garantir a coleta de todo o anticorpo anti-Gr1 presente no sobrenadante, evitando assim a perda de anticorpos devida a saturação da coluna de proteína G. Após a coleta, o eluato foi dialisado em $4000 \mathrm{~mL}$ de PBS1 x, sendo trocado a cada 2 horas. Por último, deixamos as amostras por 12 horas em $4000 \mathrm{~mL}$ de 
PBS 1x. Após a diálise, a quantificação proteica foi realizada em espectrofotometria de cubeta, na qual consideramos a OD de 0,8 equivalente a concentração proteica de $1 \mathrm{mg} / \mathrm{mL}$.

\subsubsection{Depleção de neutrófilos em animais C57BI/6:}

Após obtenção e purificação dos anticorpos anti-Gr1, padronizamos a quantidade de anti-Gr1 necessária para depleção dos neutrófilos em animais C57BI/6 WT. Diferentes quantidades de anti-Gr1 ou anti-LTF2 (isotipo controle BioXCell) foram administrados i.p. nos animais, e seus níveis de neutrófilos circulantes foram acompanhados por 3 dias por meio de esfregaço sanguíneo ou cytospin. O sangue foi obtido pela cauda do animal e as amostras foram coradas (kit Instant-Prov - NewProv) para contagem diferencial dos leucócitos.

\subsection{Infecção intraperitoneal de animais C57BI/6 WT e neutropênicos com conídios de $F$. pedrosoi:}

Para verificação da importância dos neutrófilos in vivo na infecção por conídios de F. pedrosoi nós primeiramente causamos a neutropenia nos animais por meio do tratamento com $150 \mu \mathrm{g}$ de anti-Gr1 ou anti-LTF2 (isotipo controle) no dia -1 à infecção. No dia 0 , os animais receberam nova dose de anticorpo $(100 \mu \mathrm{g})$ e foram posteriormente infectados intraperitonealmente com $5 \times 10^{7}$ conídios de F. Pedrosoi (volume de $200 \mu \mathrm{l}$ ). Para os grupos de animais infectados por 14 dias, outras duas doses de anticorpos $(100 \mu \mathrm{g})$ foram ministradas no dia 3 e no dia 7 de infecção. Após 1, 2 e 14 dias de infecção os animais foram eutanasiados em câmara de $\mathrm{CO}_{2}$ e o sangue, baço e fígado foram coletados para posteriores análises de: CFU, citocinas e imunofenotipagem, conforme descrito nos itens 3.9.1, 3.9.2 e 3.9.3, respectivamente. No grupo de animais infectados por 14 dias, nós também realizamos a análise de linfoproliferação e da produção de anticorpos específicos contra a F. pedrosoi conforme descritos abaixo.

\subsubsection{Avaliação da ativação de linfócitos $T$ :}

Após obtenção e contagem das células do baço dos animais infectados com F. pedrosoi pelo período de 14, utilizamos o kit de Carboxifluoresceína succinimidil éster (CFSE - Thermo Fischer) para a realização do ensaio de 
linfoproliferação, conforme instruções do fabricante. Brevemente, ressuspendemos $1 \times 10^{7}$ células em $1 \mathrm{~mL}$ de $\mathrm{R} 10$ e adicionamos o volume de 1,5 $\mu \mathrm{l}$ de CFSE por 10 minutos a $37^{\circ} \mathrm{C}$ protegido da luz, realizando a homogeneização das células a cada 2 minutos, para garantir a marcação homogênea das mesmas. Após incubação, $5 \mathrm{~mL}$ de RPMI foi adicionado e as células mantidas em gelo por 5 minutos. Após lavagens, uma alíquota foi coletada para confirmação da marcação das células pelo CFSE no FACS Canto II. Após confirmação da marcação, $3 \times 10^{5}$ células foram cultivadas com meio R10 em placa de 96 poços por 3 dias na presença ou ausência de Fitohemaglutinina (mitógeno utilizado como estímulo à proliferação celular) ou de proteínas extraída de $F$. pedrosoi. O índice de linfoproliferação foi analisado por citometria de fluxo.

\subsubsection{Avaliação da produção de anticorpos específicos contra $F$. pedrosoi}

Após coleta sanguínea dos animais infectados por 14 dias, as amostras foram centrifugadas a $4^{\circ} \mathrm{C}$ por $500 \mathrm{x} g$ por 5 minutos para coleta do plasma sanguíneo. Após coleta, as amostras foram mantidas em $-20^{\circ} \mathrm{C}$ até momento de uso. Para analisarmos a produção específica de anticorpos produzidos na infecção, primeiramente fizemos a obtenção dos antígenos total de $F$. pedrosoi da seguinte forma: As colônias de F. pedrosoi foram coletadas de tubos contendo ágar Sabouraud e colocadas em pistillo onde foi adicionado nitrogênio líquido para posterior maceração com cadinho. Esse passo foi repetido ao menos 5 vezes, até que um pó bem fino fosse obtido. Esse material foi então coletado com PBS 1x e centrifugado a 5000 rpm por 10 minutos para que o sobrenadante rico em proteínas fosse coletado. Posteriormente a dosagem de proteínas foi realizada utilizando o kit de Bradford. Após obtenção dos antígenos, a produção de anticorpos específicos contra $F$. pedrosoi foi observada utilizando a técnica de eletroforese em gel de poliacrilamida (SDS-PAGE) seguida de Western Blot (WB). Primeiramente, preparamos gel SDS-PAGE de 15\% (1 mm) e aplicamos um total de $15 \mu \mathrm{g}$ de proteína total do F. pedrosoi por poço (tampão de amostra contendo $\beta$-mercaptoetanol). Após realizada a eletroforese, as amostras foram transferidas para membrana de nitrocelulose e posteriormente bloqueadas por 2 horas com solução de 0,05\% PBS-T contendo 5\% de BSA. 
Após lavagens com PBS-T, adicionamos o soro dos animais diluídos 1:200 em PBS-T por 2 horas a temperatura ambiente. Após diversas lavagens com PBST incubamos as membranas com anticorpo lgG de cabra anti-mouse conjugado com peroxidase na diluição de 1:3000 em PBS-T por mais 2 horas. Após lavagens adicionamos ECL Western Blotting Substrate (Thermo Fischer) por 2 minutos e utilizamos o equipamento LAS 500 para revelar a membrana. 


\section{REFERÊNCIAS BIBLIOGRÁFICAS}

1. Queiróz AJR, Pereira Domingos F, Antônio JR. Chromoblastomycosis: clinical experience and review of literature. Int J Dermatol. 2018;57(11):1351-5.

2. Caligiorne RB, de Resende MA, Dias-Neto E, Oliveira SC, Azevedo V. Dematiaceous fungal pathogens: analysis of ribosomal DNA gene polymorphism by polymerase chain reaction-restriction fragment length polymorphism. Mycoses. 1999;42(11-12):609-14.

3. Pedroso A. Sobre quatro casos de dermatite verrucosa produzida pela Phialophora verrucosa. In: Gomes J, editor. An Paul Med Cir 1920. p. 53-61.

4. Queiroz-Telles F, de Hoog S, Santos DW, Salgado CG, Vicente VA, Bonifaz A, et al. Chromoblastomycosis. Clin Microbiol Rev. 2017;30(1):233-76.

5. M. R. Über die brasilianische "Figueira" (Vorläufige Mitteilung). Arch Schiffs Trop Hyg 1914. p. 498-

9.

6. P N. Estudio del primer caso Argentino de cromomicosis, Fonsecaea (Negroni) pedrosoi (Brumpt 1921). . Rev Inst Bacteriol 1936. p. 419-26.

7. Terra F, Torres M, da Fonseca O, AE AL. Novo typo de dermatite verrucosa mycose por Acrotheca com associacao de leishmaniosa. Bras Med 1922;2.

8. M M, F A. Etiologic agents of chromomycosis (chromoblastomycosis of Terra, Torres, Fonseca and Leão, 1922) of North and South America . . Rev Biol Hyg 1935;6:94-7.

9. Odds FC, Arai T, Disalvo AF, Evans EG, Hay RJ, Randhawa HS, et al. Nomenclature of fungal diseases: a report and recommendations from a Sub-Committee of the International Society for Human and Animal Mycology (ISHAM). J Med Vet Mycol. 1992;30(1):1-10.

10. Silva JP, de Souza W, Rozental S. Chromoblastomycosis: a retrospective study of 325 cases on Amazonic Region (Brazil). Mycopathologia. 1998;143(3):171-5.

11. JW R. Chromoblastomycosis. WB S, editor. Phildelphia: Harbour Brace Jovanovich Inc; 1988.

12. Kwon-Chung KJ BJ. Chromoblastomycosis. . S CCH, editor. Philadelphia.: Lea and Febiger Inc.,; 1992.

13. Brandt ME, Warnock DW. Epidemiology, clinical manifestations, and therapy of infections caused by dematiaceous fungi. J Chemother. 2003;15 Suppl 2:36-47.

14. Minotto R, Bernardi CD, Mallmann LF, Edelweiss MI, Scroferneker ML. Chromoblastomycosis: a review of 100 cases in the state of Rio Grande do Sul, Brazil. J Am Acad Dermatol. 2001;44(4):585-92.

15. Esterre P, Andriantsimahavandy A, Ramarcel ER, Pecarrere JL. Forty years of chromoblastomycosis in Madagascar: a review. Am J Trop Med Hyg. 1996;55(1):45-7.

16. Bonifaz A, Carrasco-Gerard E, Saúl A. Chromoblastomycosis: clinical and mycologic experience of 51 cases. Mycoses. 2001;44(1-2):1-7.

17. Esterre P, Queiroz-Telles F. Management of chromoblastomycosis: novel perspectives. Curr Opin Infect Dis. 2006;19(2):148-52.

18. Bittencourt AL, Londero AT, Andrade JA. [Auricular chromoblastomycosis. A case report]. Rev Inst Med Trop Sao Paulo. 1994;36(4):381-3.

19. Höfling-Lima AL, Guarro J, Freitas D, Godoy P, Gené J, Souza LB, et al. Clinical treatment of corneal infection due to Fonsecaea pedrosoi--case report. Arq Bras Oftalmol. 2005;68(2):270-2.

20. Salgado CG, da Silva JP, da Silva MB, da Costa PF, Salgado UI. Cutaneous diffuse chromoblastomycosis. Lancet Infect Dis. 2005;5(8):528.

21. López Martínez R, Méndez Tovar LJ. Chromoblastomycosis. Clin Dermatol. 2007;25(2):188-94.

22. Santos AL, Palmeira VF, Rozental S, Kneipp LF, Nimrichter L, Alviano DS, et al. Biology and pathogenesis of Fonsecaea pedrosoi, the major etiologic agent of chromoblastomycosis. FEMS Microbiol Rev. 2007;31(5):570-91.

23. Correia RT, Valente NY, Criado PR, Martins JE. Chromoblastomycosis: study of 27 cases and review of medical literature. An Bras Dermatol. 2010;85(4):448-54.

24. Bonifaz A, Martínez-Soto E, Carrasco-Gerard E, Peniche J. Treatment of chromoblastomycosis with itraconazole, cryosurgery, and a combination of both. Int J Dermatol. 1997;36(7):542-7.

25. Bonifaz A, Paredes-Solís V, Saúl A. Treating chromoblastomycosis with systemic antifungals. Expert Opin Pharmacother. 2004;5(2):247-54.

26. Poirriez J, Breuillard F, Francois N, Fruit J, Sendid B, Gross S, et al. A case of chromomycosis treated by a combination of cryotherapy, shaving, oral 5-fluorocytosine, and oral amphotericin $\mathrm{B}$. Am J Trop Med Hyg. 2000;63(1-2):61-3.

27. Castro LG, Pimentel ER, Lacaz CS. Treatment of chromomycosis by cryosurgery with liquid nitrogen: 15 years' experience. Int J Dermatol. 2003;42(5):408-12.

28. Lupi O, Tyring SK, McGinnis MR. Tropical dermatology: fungal tropical diseases. J Am Acad Dermatol. 2005;53(6):931-51, quiz 52-4.

29. Hira K, Yamada H, Takahashi Y, Ogawa H. Successful treatment of chromomycosis using carbon dioxide laser associated with topical heat applications. J Eur Acad Dermatol Venereol. 2002;16(3):273-5.

30. Marques GF, Masuda PY, Sousa JM, Barreto JA, Wachholz PA. Clinical and demographic profile of chromoblastomycosis in a referral service in the midwest of São Paulo state (Brazil). An Bras Dermatol. 2015;90(1):140-2. 
31. Esterre P, Peyrol S, Sainte-Marie D, Pradinaud R, Grimaud JA. Granulomatous reaction and tissue remodelling in the cutaneous lesion of chromomycosis. Virchows Arch A Pathol Anat Histopathol. 1993;422(4):285-91.

32. Hamza SH, Mercado PJ, Skelton HG, Smith KJ. An unusual dematiaceous fungal infection of the skin caused by Fonsecaea pedrosoi: a case report and review of the literature. J Cutan Pathol. 2003;30(5):340-3.

33. Rosen T, Overholt M. Persistent viability of the Medlar body. Int J Dermatol. 1996;35(2):96-8.

34. Erwig LP, Gow NA. Interactions of fungal pathogens with phagocytes. Nat Rev Microbiol. 2016;14(3):163-76.

35. Gómez BL, Nosanchuk JD. Melanin and fungi. Curr Opin Infect Dis. 2003;16(2):91-6.

36. Souza ET, Silva-Filho FC, De Souza W, Alviano CS, Angluster J, Travassos LR. Identification of sialic acids on the cell surface of hyphae and conidia of the human pathogen Fonsecaea pedrosoi. J Med Vet Mycol. 1986;24(2):145-54.

37. Gomes $\mathrm{MH}$, Resende MA. Fonsecaea pedrosoi: lipid composition and determination of susceptibility to amphotericin B. Can J Microbiol. 1992;38(3):209-14.

38. de A Soares RM, Angluster J, de Souza W, Alviano CS. Carbohydrate and lipid components of hyphae and conidia of human pathogen Fonsecaea pedrosoi. Mycopathologia. 1995;132(2):71-7.

39. Janeway CA, Medzhitov R. Innate immune recognition. Annu Rev Immunol. 2002;20:197-216.

40. Yatim KM, Lakkis FG. A brief journey through the immune system. Clin J Am Soc Nephrol. 2015;10(7):1274-81.

41. de Visser KE, Eichten A, Coussens LM. Paradoxical roles of the immune system during cancer development. Nat Rev Cancer. 2006;6(1):24-37.

42. Hawlisch H, Köhl J. Complement and Toll-like receptors: key regulators of adaptive immune responses. Mol Immunol. 2006;43(1-2):13-21.

43. Pradeu T, Du Pasquier L. Immunological memory: What's in a name? Immunol Rev. 2018;283(1):7-

20.

44. Netea MG, Schlitzer A, Placek K, Joosten LAB, Schultze JL. Innate and Adaptive Immune Memory: an Evolutionary Continuum in the Host's Response to Pathogens. Cell Host Microbe. 2019;25(1):13-26.

45. Netea MG, Quintin J, van der Meer JW. Trained immunity: a memory for innate host defense. Cell Host Microbe. 2011;9(5):355-61.

46. Gourbal B, Pinaud S, Beckers GJM, Van Der Meer JWM, Conrath U, Netea MG. Innate immune memory: An evolutionary perspective. Immunol Rev. 2018;283(1):21-40.

47. Riera Romo M, Pérez-Martínez D, Castillo Ferrer C. Innate immunity in vertebrates: an overview. Immunology. 2016;148(2):125-39.

48. Hoffmann J, Akira S. Innate immunity. Curr Opin Immunol. 2013;25(1):1-3.

49. Moresco EM, LaVine D, Beutler B. Toll-like receptors. Curr Biol. 2011;21(13):R488-93.

50. Janeway CA. Approaching the asymptote? Evolution and revolution in immunology. Cold Spring Harb Symp Quant Biol. 1989;54 Pt 1:1-13.

51. Chtarbanova S, Imler JL. Microbial sensing by Toll receptors: a historical perspective. Arterioscler Thromb Vasc Biol. 2011;31(8):1734-8.

52. Anderson KV, Nüsslein-Volhard C. Information for the dorsal--ventral pattern of the Drosophila embryo is stored as maternal mRNA. Nature. 1984;311(5983):223-7.

53. Lemaitre B, Nicolas E, Michaut L, Reichhart JM, Hoffmann JA. The dorsoventral regulatory gene cassette spätzle/Toll/cactus controls the potent antifungal response in Drosophila adults. Cell. 1996;86(6):973-83.

54. Medzhitov R, Preston-Hurlburt $\mathrm{P}$, Janeway CA. A human homologue of the Drosophila Toll protein signals activation of adaptive immunity. Nature. 1997;388(6640):394-7.

55. Poltorak A, He X, Smirnova I, Liu MY, Van Huffel C, Du X, et al. Defective LPS signaling in C3H/HeJ and C57BL/10ScCr mice: mutations in TIr4 gene. Science. 1998;282(5396):2085-8.

56. Akira S, Uematsu S, Takeuchi O. Pathogen recognition and innate immunity. Cell. 2006;124(4):783-801.

57. Anwar MA, Shah M, Kim J, Choi S. Recent clinical trends in Toll-like receptor targeting therapeutics. Med Res Rev. 2019;39(3):1053-90.

58. O'Neill LA, Golenbock D, Bowie AG. The history of Toll-like receptors - redefining innate immunity. Nat Rev Immunol. 2013;13(6):453-60.

59. Degli-Esposti MA, Smyth MJ. Close encounters of different kinds: dendritic cells and NK cells take centre stage. Nat Rev Immunol. 2005;5(2):112-24.

60. Johansson M, Denardo DG, Coussens LM. Polarized immune responses differentially regulate cancer development. Immunol Rev. 2008;222:145-54.

61. van Spriel AB, de Jong EC. Dendritic cell science: more than 40 years of history. J Leukoc Biol. 2013;93(1):33-8.

62. Kasamatsu J. Evolution of innate and adaptive immune systems in jawless vertebrates. Microbiol Immunol. 2013;57(1):1-12.

63. Batista FD, Harwood NE. The who, how and where of antigen presentation to B cells. Nat Rev Immunol. 2009;9(1):15-27.

64. Pape KA, Catron DM, Itano AA, Jenkins MK. The humoral immune response is initiated in lymph nodes by $B$ cells that acquire soluble antigen directly in the follicles. Immunity. 2007;26(4):491-502. 
65. Balázs M, Martin F, Zhou T, Kearney J. Blood dendritic cells interact with splenic marginal zone B cells to initiate T-independent immune responses. Immunity. 2002;17(3):341-52.

66. Martínez-Riaño A, Bovolenta ER, Mendoza P, Oeste CL, Martín-Bermejo MJ, Bovolenta P, et al. Antigen phagocytosis by B cells is required for a potent humoral response. EMBO Rep. 2018;19(9).

67. Sharma G, Holt RA. T-cell epitope discovery technologies. Hum Immunol. 2014;75(6):514-9.

68. Kurita N. Cell-mediated immune responses in mice infected with Fonsecaea pedrosoi. Mycopathologia. 1979;68(1):9-15.

69. Ahrens J, Graybill JR, Abishawl A, Tio FO, Rinaldi MG. Experimental murine chromomycosis mimicking chronic progressive human disease. Am J Trop Med Hyg. 1989;40(6):651-8.

70. Mazo Fávero Gimenes V, Da Glória de Souza M, Ferreira KS, Marques SG, Gonçalves AG, Vagner de Castro Lima Santos D, et al. Cytokines and lymphocyte proliferation in patients with different clinical forms of chromoblastomycosis. Microbes Infect. 2005;7(4):708-13.

71. Sousa MG, de Maria Pedrozo e Silva Azevedo C, Nascimento RC, Ghosn EE, Santiago KL, Noal $\mathrm{V}$, et al. Fonsecaea pedrosoi infection induces differential modulation of costimulatory molecules and cytokines in monocytes from patients with severe and mild forms of chromoblastomycosis. J Leukoc Biol. 2008;84(3):864-70.

72. Teixeira de Sousa MaG, Ghosn EE, Almeida SR. Absence of CD4+ T cells impairs host defence of mice infected with Fonsecaea pedrosoi. Scand J Immunol. 2006;64(6):595-600.

73. Silva AA, Criado PR, Nunes RS, da Silva WL, Kanashiro-Galo L, Duarte MI, et al. In situ immune response in human chromoblastomycosis--a possible role for regulatory and Th17 T cells. PLoS Negl Trop Dis. 2014;8(9):e3162.

74. Wüthrich M, Wang H, Li M, Lerksuthirat T, Hardison SE, Brown GD, et al. Fonsecaea pedrosoiinduced Th17-cell differentiation in mice is fostered by Dectin-2 and suppressed by Mincle recognition. Eur J Immunol. 2015;45(9):2542-52.

75. Dong B, Li D, Li R, Chen SC, Liu W, Chen L, et al. A chitin-like component on sclerotic cells of Fonsecaea pedrosoi inhibits Dectin-1-mediated murine Th17 development by masking $\beta$-glucans. PLoS One. 2014;9(12):e114113.

76. Ibrahim-Granet $\mathrm{O}$, de Bièvre $\mathrm{C}$, Jendoubi M. Immunochemical characterisation of antigens and growth inhibition of Fonsecaea pedrosoi by species-specific IgG. J Med Microbiol. 1988;26(3):217-22.

77. Alviano DS, Franzen AJ, Travassos LR, Holandino C, Rozental S, Ejzemberg R, et al. Melanin from Fonsecaea pedrosoi induces production of human antifungal antibodies and enhances the antimicrobial efficacy of phagocytes. Infect Immun. 2004;72(1):229-37.

78. Machado AP, Silva MR, Fischman O. Prolonged infection by Fonsecaea pedrosoi after antigenic co-stimulation at different sites in experimental murine chromoblastomycosis. Virulence. 2010;1(1):29-36.

79. Esterre $P$, Jahevitra $M$, Andriantsimahavandy $A$. Humoral immune response in chromoblastomycosis during and after therapy. Clin Diagn Lab Immunol. 2000;7(3):497-500.

80. Torinuki W, Okohchi K, Takematsu H, Tagami H. Activation of the alternative complement pathway by Fonsecaea pedrosoi. J Invest Dermatol. 1984;83(4):308-10.

81. Pinto L, Granja LF, Alviano DS, da Silva MH, Alviano CS, Ejzemberg R. Activation of the human complement system by pigmented and hypopigmented mycelia of the fungus Fonsecaea pedrosoi. Mycoses. 2011;54(5):e474-80.

82. Pinto L, Granja LFZ, Almeida MA, Alviano DS, Silva MHD, Ejzemberg R, et al. Melanin particles isolated from the fungus Fonsecaea pedrosoi activates the human complement system. Mem Inst Oswaldo Cruz. 2018;113(8):e180120.

83. Farbiarz SR, De Carvalho TU, Alviano C, De Souza W. Fine structure and cytochemistry of the interaction between Fonsecaea pedrosoi and mouse resident macrophages. $\mathrm{J}$ Med Vet Mycol. 1990;28(5):373-83.

84. Rozental S, Alviano CS, de Souza W. The in vitro susceptibility of Fonsecaea pedrosoi to activated macrophages. Mycopathologia. 1994;126(2):85-91.

85. Hayakawa M, Ghosn EE, da Gloria Teixeria de Sousa M, Ferreira KS, Almeida SR. Phagocytosis, production of nitric oxide and pro-inflammatory cytokines by macrophages in the presence of dematiaceous [correction of dematiaceus] fungi that cause chromoblastomycosis. Scand J Immunol. 2006;64(4):382-7.

86. Bocca AL, Brito PP, Figueiredo F, Tosta CE. Inhibition of nitric oxide production by macrophages in chromoblastomycosis: a role for Fonsecaea pedrosoi melanin. Mycopathologia. 2006;161(4):195-203.

87. da Silva JP, da Silva MB, Salgado UI, Diniz JA, Rozental S, Salgado CG. Phagocytosis of Fonsecaea pedrosoi conidia, but not sclerotic cells caused by Langerhans cells, inhibits CD40 and B7-2 expression. FEMS Immunol Med Microbiol. 2007;50(1):104-11.

88. Sousa MG, Ghosn EE, Nascimento RC, Bomfim GF, Noal V, Santiago K, et al. Monocyte-derived dendritic cells from patients with severe forms of chromoblastomycosis induce CD4+ T cell activation in vitro. Clin Exp Immunol. 2009;156(1):117-25.

89. Taylor PR, Leal SM, Sun Y, Pearlman E. Aspergillus and Fusarium corneal infections are regulated by Th17 cells and IL-17-producing neutrophils. J Immunol. 2014;192(7):3319-27.

90. Röhm M, Grimm MJ, D'Auria AC, Almyroudis NG, Segal BH, Urban CF. NADPH oxidase promotes neutrophil extracellular trap formation in pulmonary aspergillosis. Infect Immun. 2014;82(5):1766-77.

91. Tavian EG, Dias-Melicio LA, Acorci MJ, Graciani AP, Peraçoli MT, Soares AM. Interleukin-15 increases Paracoccidioides brasiliensis killing by human neutrophils. Cytokine. 2008;41(1):48-53. 
92. Richardson M, Rautemaa R. How the host fights against Candida infections. Front Biosci (Schol Ed). 2009;1:246-57.

93. Rozental S, Alviano CS, de Souza W. Fine structure and cytochemical study of the interaction between Fonsecaea pedrosoi and rat polymorphonuclear leukocyte. J Med Vet Mycol. 1996;34(5):323-30.

94. Machado AP, Silva MR, Fischman O. Local phagocytic responses after murine infection with different forms of Fonsecaea pedrosoi and sclerotic bodies originating from an inoculum of conidiogenous cells. Mycoses. 2011;54(3):202-11.

95. Ogawa MM, Mariano M, Silva MRR, Enokihara MMSE, Michalany NS, Nishikaku AS, et al. Study of tissue inflammatory response in different mice strains infected by dematiaceous fungi Fonsecaea pedrosoi. An Bras Dermatol. 2019;94(1):29-36.

96. Drummond RA, Dambuza IM, Vautier S, Taylor JA, Reid DM, Bain CC, et al. CD4(+) T-cell survival in the GI tract requires dectin-1 during fungal infection. Mucosal Immunol. 2016;9(2):492-502.

97. Griffiths JS, Thompson A, Stott M, Benny A, Lewis NA, Taylor PR, et al. Differential susceptibility of Dectin-1 isoforms to functional inactivation by neutrophil and fungal proteases. FASEB J. 2018;32(6):3385-97.

98. Carrion SeJ, Leal SM, Ghannoum MA, Aimanianda V, Latgé JP, Pearlman E. The RodA hydrophobin on Aspergillus fumigatus spores masks dectin-1- and dectin-2-dependent responses and enhances fungal survival in vivo. J Immunol. 2013;191(5):2581-8.

99. McDonald JU, Rosas M, Brown GD, Jones SA, Taylor PR. Differential dependencies of monocytes and neutrophils on dectin-1, dectin-2 and complement for the recognition of fungal particles in inflammation. PLoS One. 2012;7(9):e45781.

100. Wells CA, Salvage-Jones JA, Li X, Hitchens K, Butcher S, Murray RZ, et al. The macrophageinducible C-type lectin, mincle, is an essential component of the innate immune response to Candida albicans. J Immunol. 2008;180(11):7404-13.

101. Goyal S, Castrillón-Betancur JC, Klaile E, Slevogt H. The Interaction of Human Pathogenic Fungi With C-Type Lectin Receptors. Front Immunol. 2018;9:1261.

102. Drummond RA, Gaffen SL, Hise AG, Brown GD. Innate Defense against Fungal Pathogens. Cold Spring Harb Perspect Med. 2014;5(6).

103. Wevers BA, Kaptein TM, Zijlstra-Willems EM, Theelen B, Boekhout T, Geijtenbeek TB, et al. Fungal engagement of the $C$-type lectin mincle suppresses dectin-1-induced antifungal immunity. Cell Host Microbe. 2014;15(4):494-505.

104. Sousa MaG, Reid DM, Schweighoffer E, Tybulewicz V, Ruland J, Langhorne J, et al. Restoration of pattern recognition receptor costimulation to treat chromoblastomycosis, a chronic fungal infection of the skin. Cell Host Microbe. 2011;9(5):436-43.

105. Siqueira IM, de Castro RJA, Leonhardt LCM, Jerônimo MS, Soares AC, Raiol T, et al. Modulation of the immune response by Fonsecaea pedrosoi morphotypes in the course of experimental chromoblastomycosis and their role on inflammatory response chronicity. PLoS Negl Trop Dis. 2017;11(3):e0005461.

106. Gazendam RP, van de Geer A, Roos D, van den Berg TK, Kuijpers TW. How neutrophils kill fungi. Immunol Rev. 2016;273(1):299-311.

107. Gazendam RP, van Hamme JL, Tool AT, Hoogenboezem M, van den Berg JM, Prins JM, et al. Human Neutrophils Use Different Mechanisms To Kill Aspergillus fumigatus Conidia and Hyphae: Evidence from Phagocyte Defects. J Immunol. 2016;196(3):1272-83.

108. Edwards S. The development and structure of mature neutrophils. . Biochemistry and Physiology of the Neutrophil2005. p. 33-76.

109. Basu S, Hodgson G, Katz M, Dunn AR. Evaluation of role of G-CSF in the production, survival, and release of neutrophils from bone marrow into circulation. Blood. 2002;100(3):854-61.

110. Dancey JT, Deubelbeiss KA, Harker LA, Finch CA. Neutrophil kinetics in man. J Clin Invest. 1976;58(3):705-15.

111. Mayadas TN, Cullere X. Neutrophil beta2 integrins: moderators of life or death decisions. Trends Immunol. 2005;26(7):388-95.

112. Mayadas TN, Cullere $X$, Lowell CA. The multifaceted functions of neutrophils. Annu Rev Pathol. 2014;9:181-218.

113. Furze RC, Rankin SM. Neutrophil mobilization and clearance in the bone marrow. Immunology. 2008;125(3):281-8.

114. Schymeinsky J, Mócsai A, Walzog B. Neutrophil activation via beta2 integrins (CD11/CD18): molecular mechanisms and clinical implications. Thromb Haemost. 2007;98(2):262-73.

115. Daëron M, Jaeger S, Du Pasquier L, Vivier E. Immunoreceptor tyrosine-based inhibition motifs: a quest in the past and future. Immunol Rev. 2008;224:11-43.

116. Baldridge C, Gerard R. The extra respiration of phagocytosis. Am J Physiol 1933. p. 235-6.

117. Bylund J, Brown KL, Movitz C, Dahlgren C, Karlsson A. Intracellular generation of superoxide by the phagocyte NADPH oxidase: how, where, and what for? Free Radic Biol Med. 2010;49(12):1834-45.

118. Babior BM, Curnutte JT, McMurrich BJ. The particulate superoxide-forming system from human neutrophils. Properties of the system and further evidence supporting its participation in the respiratory burst. J Clin Invest. 1976;58(4):989-96.

119. Babior BM. NADPH oxidase: an update. Blood. 1999;93(5):1464-76. 
120. Boyle KB, Gyori D, Sindrilaru A, Scharffetter-Kochanek K, Taylor PR, Mócsai A, et al. Class IA phosphoinositide 3-kinase $\beta$ and $\delta$ regulate neutrophil oxidase activation in response to Aspergillus fumigatus hyphae. J Immunol. 2011;186(5):2978-89.

121. Berka $V$, Wang LH, Tsai AL. Oxygen-induced radical intermediates in the nNOS oxygenase domain regulated by L-arginine, tetrahydrobiopterin, and thiol. Biochemistry. 2008;47(1):405-20.

122. Bogdan C. Nitric oxide and the immune response. Nat Immunol. 2001;2(10):907-16.

123. Miwa M, Stuehr DJ, Marletta MA, Wishnok JS, Tannenbaum SR. Nitrosation of amines by stimulated macrophages. Carcinogenesis. 1987;8(7):955-8.

124. Stuehr DJ, Marletta MA. Mammalian nitrate biosynthesis: mouse macrophages produce nitrite and nitrate in response to Escherichia coli lipopolysaccharide. Proc Natl Acad Sci U S A. 1985;82(22):7738-42.

125. Wang B, Sullivan J, Sullivan GW, Mandell GL. Interaction of leptospires with human polymorphonuclear neutrophils. Infect Immun. 1984;44(2):459-64.

126. Menten-Dedoyart C, Faccinetto C, Golovchenko M, Dupiereux I, Van Lerberghe PB, Dubois S, et al. Neutrophil extracellular traps entrap and kill Borrelia burgdorferi sensu stricto spirochetes and are not affected by Ixodes ricinus tick saliva. J Immunol. 2012;189(11):5393-401.

127. Restrepo A, Vélez $H$. [Effect of phagocytosis in vitro on Paracoccidioides brasiliensis]. Sabouraudia. 1975;13 Pt 1:10-21.

128. Urban CF, Reichard U, Brinkmann V, Zychlinsky A. Neutrophil extracellular traps capture and kill Candida albicans yeast and hyphal forms. Cell Microbiol. 2006;8(4):668-76.

129. Fulurija A, Ashman RB, Papadimitriou JM. Neutrophil depletion increases susceptibility to systemic and vaginal candidiasis in mice, and reveals differences between brain and kidney in mechanisms of host resistance. Microbiology. 1996;142 ( Pt 12):3487-96.

130. Mircescu MM, Lipuma L, van Rooijen N, Pamer EG, Hohl TM. Essential role for neutrophils but not alveolar macrophages at early time points following Aspergillus fumigatus infection. J Infect Dis. 2009;200(4):647-56.

131. McCormick A, Heesemann L, Wagener J, Marcos V, Hartl D, Loeffler J, et al. NETs formed by human neutrophils inhibit growth of the pathogenic mold Aspergillus fumigatus. Microbes Infect. 2010;12(1213):928-36

132. Wang $Y J$, Wei $X Y$, Jing $X Q$, Chang $Y L$, Hu CH, Wang $X$, et al. The Fundamental Role of NOX Family Proteins in Plant Immunity and Their Regulation. Int J Mol Sci. 2016;17(6).

133. COHN ZA, HIRSCH JG. The isolation and properties of the specific cytoplasmic granules of rabbit polymorphonuclear leucocytes. J Exp Med. 1960;112:983-1004.

134. ZUCKER-FRANKLIN D, HIRSCH JG. ELECTRON MICROSCOPE STUDIES ON THE DEGRANULATION OF RABBIT PERITONEAL LEUKOCYTES DURING PHAGOCYTOSIS. J Exp Med. 1964;120:569-76.

135. Jan MS, Huang YH, Shieh B, Teng RH, Yan YP, Lee YT, et al. CC chemokines induce neutrophils to chemotaxis, degranulation, and alpha-defensin release. J Acquir Immune Defic Syndr. 2006;41(1):6-16.

136. Borregaard N, Cowland JB. Granules of the human neutrophilic polymorphonuclear leukocyte. Blood. 1997;89(10):3503-21.

137. Bainton DF. Distinct granule populations in human neutrophils and lysosomal organelles identified by immuno-electron microscopy. J Immunol Methods. 1999;232(1-2):153-68.

138. Borregaard N, Sørensen OE, Theilgaard-Mönch K. Neutrophil granules: a library of innate immunity proteins. Trends Immunol. 2007;28(8):340-5.

139. Sheppard FR, Kelher MR, Moore EE, McLaughlin NJ, Banerjee A, Silliman CC. Structural organization of the neutrophil NADPH oxidase: phosphorylation and translocation during priming and activation. J Leukoc Biol. 2005;78(5):1025-42.

140. Brinkmann V, Reichard U, Goosmann C, Fauler B, Uhlemann Y, Weiss DS, et al. Neutrophil extracellular traps kill bacteria. Science. 2004;303(5663):1532-5.

141. Steinberg BE, Grinstein S. Unconventional roles of the NADPH oxidase: signaling, ion homeostasis, and cell death. Sci STKE. 2007;2007(379):pe11.

142. Clark SR, Ma AC, Tavener SA, McDonald B, Goodarzi Z, Kelly MM, et al. Platelet TLR4 activates neutrophil extracellular traps to ensnare bacteria in septic blood. Nat Med. 2007;13(4):463-9.

143. Yousefi S, Mihalache C, Kozlowski E, Schmid I, Simon HU. Viable neutrophils release mitochondrial DNA to form neutrophil extracellular traps. Cell Death Differ. 2009;16(11):1438-44.

144. Pilsczek FH, Salina D, Poon KK, Fahey C, Yipp BG, Sibley CD, et al. A novel mechanism of rapid nuclear neutrophil extracellular trap formation in response to Staphylococcus aureus. J Immunol. 2010;185(12):7413-25.

145. Douda DN, Khan MA, Grasemann H, Palaniyar N. SK3 channel and mitochondrial ROS mediate NADPH oxidase-independent NETosis induced by calcium influx. Proc Natl Acad Sci $U S A$. 2015;112(9):2817-22.

146. Fuchs TA, Abed U, Goosmann C, Hurwitz R, Schulze I, Wahn V, et al. Novel cell death program leads to neutrophil extracellular traps. J Cell Biol. 2007;176(2):231-41.

147. Yipp BG, Kubes P. NETosis: how vital is it? Blood. 2013;122(16):2784-94.

148. Medina E. Neutrophil extracellular traps: a strategic tactic to defeat pathogens with potential consequences for the host. J Innate Immun. 2009;1(3):176-80. 
149. Buchanan JT, Simpson AJ, Aziz RK, Liu GY, Kristian SA, Kotb M, et al. DNase expression allows the pathogen group A Streptococcus to escape killing in neutrophil extracellular traps. Curr Biol. 2006;16(4):396-400.

150. Guiducci E, Lemberg C, Küng N, Schraner E, Theocharides APA, LeibundGut-Landmann S. Induced NETosis Is Independent of Peptidylarginine Deiminase 4. Front Immunol. 2018;9:1573.

151. Byrd AS, O'Brien XM, Johnson CM, Lavigne LM, Reichner JS. An extracellular matrix-based mechanism of rapid neutrophil extracellular trap formation in response to Candida albicans. J Immunol. 2013;190(8):4136-48.

152. Lee MJ, Liu H, Barker BM, Snarr BD, Gravelat FN, Al Abdallah Q, et al. The Fungal Exopolysaccharide Galactosaminogalactan Mediates Virulence by Enhancing Resistance to Neutrophil Extracellular Traps. PLoS Pathog. 2015;11(10):e1005187.

153. Bruns S, Kniemeyer O, Hasenberg M, Aimanianda V, Nietzsche S, Thywissen A, et al. Production of extracellular traps against Aspergillus fumigatus in vitro and in infected lung tissue is dependent on invading neutrophils and influenced by hydrophobin RodA. PLoS Pathog. 2010;6(4):e1000873.

154. Springer DJ, Ren P, Raina R, Dong Y, Behr MJ, McEwen BF, et al. Extracellular fibrils of pathogenic yeast Cryptococcus gattii are important for ecological niche, murine virulence and human neutrophil interactions. PLoS One. 2010;5(6):e10978.

155. Mejía SP, Cano LE, López JA, Hernandez O, González Á. Human neutrophils produce extracellular traps against Paracoccidioides brasiliensis. Microbiology. 2015;161(Pt 5):1008-17.

156. Bachiega TF, Dias-Melicio LA, Fernandes RK, de Almeida Balderramas H, Rodrigues DR, Ximenes VF, et al. Participation of dectin-1 receptor on NETs release against Paracoccidioides brasiliensis: Role on extracellular killing. Immunobiology. 2016;221(2):228-35.

157. Della Coletta AM, Bachiega TF, de Quaglia e Silva JC, Soares Â, De Faveri J, Marques SA, et al. Neutrophil Extracellular Traps Identification in Tegumentary Lesions of Patients with Paracoccidioidomycosis and Different Patterns of NETs Generation In Vitro. PLoS Negl Trop Dis. 2015;9(9):e0004037.

158. Klempner MS, Gallin JI. Separation and functional characterization of human neutrophil subpopulations. Blood. 1978;51(4):659-69.

159. Pekarek LA, Starr BA, Toledano AY, Schreiber H. Inhibition of tumor growth by elimination of granulocytes. J Exp Med. 1995;181(1):435-40.

160. Tepper RI, Coffman RL, Leder P. An eosinophil-dependent mechanism for the antitumor effect of interleukin-4. Science. 1992;257(5069):548-51.

161. Colombo MP, Ferrari G, Stoppacciaro A, Parenza M, Rodolfo M, Mavilio F, et al. Granulocyte colony-stimulating factor gene transfer suppresses tumorigenicity of a murine adenocarcinoma in vivo. J Exp Med. 1991;173(4):889-97.

162. Colombo MP, Lombardi L, Stoppacciaro A, Melani C, Parenza M, Bottazzi B, et al. Granulocyte colony-stimulating factor (G-CSF) gene transduction in murine adenocarcinoma drives neutrophil-mediated tumor inhibition in vivo. Neutrophils discriminate between G-CSF-producing and G-CSF-nonproducing tumor cells. J Immunol. 1992;149(1):113-9.

163. Young MR, Newby M, Wepsic HT. Hematopoiesis and suppressor bone marrow cells in mice bearing large metastatic Lewis lung carcinoma tumors. Cancer Res. 1987;47(1):100-5.

164. Buessow SC, Paul RD, Lopez DM. Influence of mammary tumor progression on phenotype and function of spleen and in situ lymphocytes in mice. J Natl Cancer Inst. 1984;73(1):249-55.

165. Seung LP, Rowley DA, Dubey P, Schreiber H. Synergy between T-cell immunity and inhibition of paracrine stimulation causes tumor rejection. Proc Natl Acad Sci U S A. 1995;92(14):6254-8.

166. Fridlender ZG, Sun J, Kim S, Kapoor V, Cheng G, Ling L, et al. Polarization of tumor-associated neutrophil phenotype by TGF-beta: "N1" versus "N2" TAN. Cancer Cell. 2009;16(3):183-94.

167. Gabrilovich DI, Bronte V, Chen SH, Colombo MP, Ochoa A, Ostrand-Rosenberg S, et al. The terminology issue for myeloid-derived suppressor cells. Cancer Res. 2007;67(1):425; author reply 6.

168. Bronte V, Brandau S, Chen SH, Colombo MP, Frey AB, Greten TF, et al. Recommendations for myeloid-derived suppressor cell nomenclature and characterization standards. Nat Commun. 2016;7:12150.

169. Deniset JF, Kubes P. Recent advances in understanding neutrophils. F1000Res. 2016;5:2912.

170. Sagiv JY, Michaeli J, Assi S, Mishalian I, Kisos H, Levy L, et al. Phenotypic diversity and plasticity in circulating neutrophil subpopulations in cancer. Cell Rep. 2015;10(4):562-73.

171. Youn JI, Nagaraj S, Collazo M, Gabrilovich DI. Subsets of myeloid-derived suppressor cells in tumor-bearing mice. J Immunol. 2008;181(8):5791-802.

172. Gabrilovich DI, Nagaraj S. Myeloid-derived suppressor cells as regulators of the immune system. Nat Rev Immunol. 2009;9(3):162-74.

173. Mizuno R, Kawada K, Itatani Y, Ogawa R, Kiyasu Y, Sakai Y. The Role of Tumor-Associated Neutrophils in Colorectal Cancer. Int J Mol Sci. 2019;20(3).

174. Zilio S, Serafini P. Neutrophils and Granulocytic MDSC: The Janus God of Cancer Immunotherapy. Vaccines (Basel). 2016;4(3).

175. Delano MJ, Scumpia PO, Weinstein JS, Coco D, Nagaraj S, Kelly-Scumpia KM, et al. MyD88dependent expansion of an immature GR-1(+)CD11b(+) population induces $\mathrm{T}$ cell suppression and Th2 polarization in sepsis. J Exp Med. 2007;204(6):1463-74.

176. Medina E, Hartl D. Myeloid-Derived Suppressor Cells in Infection: A General Overview. J Innate Immun. 2018;10(5-6):407-13. 
177. Mednick AJ, Feldmesser M, Rivera J, Casadevall A. Neutropenia alters lung cytokine production in mice and reduces their susceptibility to pulmonary cryptococcosis. Eur J Immunol. 2003;33(6):1744-53.

178. Li H, Han Y, Guo Q, Zhang M, Cao X. Cancer-expanded myeloid-derived suppressor cells induce anergy of NK cells through membrane-bound TGF-beta 1. J Immunol. 2009;182(1):240-9.

179. Hu CE, Gan J, Zhang RD, Cheng YR, Huang GJ. Up-regulated myeloid-derived suppressor cell contributes to hepatocellular carcinoma development by impairing dendritic cell function. Scand J Gastroenterol. 2011;46(2):156-64.

180. Greifenberg V, Ribechini E, Rössner S, Lutz MB. Myeloid-derived suppressor cell activation by combined LPS and IFN-gamma treatment impairs DC development. Eur J Immunol. 2009;39(10):2865-76.

181. Poschke I, Mao Y, Adamson L, Salazar-Onfray F, Masucci G, Kiessling R. Myeloid-derived suppressor cells impair the quality of dendritic cell vaccines. Cancer Immunol Immunother. 2012;61(6):82738.

182. Mueller-Leisse J, Brueggemann S, Bouzani M, Schmitt AL, Einsele $H$, Loeffler J. Polymorphonuclear neutrophils and granulocytic myeloid-derived suppressor cells inhibit natural killer cell activity toward Aspergillus fumigatus. Med Mycol. 2015;53(6):622-9.

183. Zhu J, Huang $\mathrm{X}$, Yang Y. Myeloid-derived suppressor cells regulate natural killer cell response to adenovirus-mediated gene transfer. J Virol. 2012;86(24):13689-96.

184. Fattorossi A, Nisini R, Pizzolo JG, D'Amelio R. New, simple flow cytometry technique to discriminate between internalized and membrane-bound particles in phagocytosis. Cytometry. 1989;10(3):320-5.

185. Tuominen-Gustafsson H, Penttinen M, Hytönen J, Viljanen MK. Use of CFSE staining of borreliae in studies on the interaction between borreliae and human neutrophils. BMC Microbiol. 2006;6:92.

186. Svobodová E, Staib P, Losse J, Hennicke F, Barz D, Józsi M. Differential interaction of the two related fungal species Candida albicans and Candida dubliniensis with human neutrophils. $\mathrm{J}$ Immunol. 2012;189(5):2502-11.

187. Jayaprakash $\mathrm{K}$, Demirel I, Khalaf $\mathrm{H}$, Bengtsson $\mathrm{T}$. The role of phagocytosis, oxidative burst and neutrophil extracellular traps in the interaction between neutrophils and the periodontal pathogen Porphyromonas gingivalis. Mol Oral Microbiol. 2015;30(5):361-75.

188. Young RL, Malcolm KC, Kret JE, Caceres SM, Poch KR, Nichols DP, et al. Neutrophil extracellular trap (NET)-mediated killing of Pseudomonas aeruginosa: evidence of acquired resistance within the CF airway, independent of CFTR. PLoS One. 2011;6(9):e23637.

189. Bonne-Année S, Kerepesi LA, Hess JA, Wesolowski J, Paumet F, Lok JB, et al. Extracellular traps are associated with human and mouse neutrophil and macrophage mediated killing of larval Strongyloides stercoralis. Microbes Infect. 2014;16(6):502-11.

190. Juneau RA, Stevens JS, Apicella MA, Criss AK. A thermonuclease of Neisseria gonorrhoeae enhances bacterial escape from killing by neutrophil extracellular traps. J Infect Dis. 2015;212(2):316-24.

191. Meier A, Kirschning CJ, Nikolaus T, Wagner H, Heesemann J, Ebel F. Toll-like receptor (TLR) 2 and TLR4 are essential for Aspergillus-induced activation of murine macrophages. Cell Microbiol. 2003;5(8):561-70.

192. Krzyściak PM, Pindycka-Piaszczyńska M, Piaszczyński M. Chromoblastomycosis. Postepy Dermatol Alergol. 2014;31(5):310-21.

193. Netea MG, Warris A, Van der Meer JW, Fenton MJ, Verver-Janssen TJ, Jacobs LE, et al. Aspergillus fumigatus evades immune recognition during germination through loss of toll-like receptor-4mediated signal transduction. J Infect Dis. 2003;188(2):320-6.

194. van der Graaf CA, Netea MG, Verschueren I, van der Meer JW, Kullberg BJ. Differential cytokine production and Toll-like receptor signaling pathways by Candida albicans blastoconidia and hyphae. Infect Immun. 2005;73(11):7458-64.

195. Ribes S, Ebert S, Regen T, Agarwal A, Tauber SC, Czesnik D, et al. Toll-like receptor stimulation enhances phagocytosis and intracellular killing of nonencapsulated and encapsulated Streptococcus pneumoniae by murine microglia. Infect Immun. 2010;78(2):865-71.

196. d'Ostiani CF, Del Sero G, Bacci A, Montagnoli C, Spreca A, Mencacci A, et al. Dendritic cells discriminate between yeasts and hyphae of the fungus Candida albicans. Implications for initiation of $T$ helper cell immunity in vitro and in vivo. J Exp Med. 2000;191(10):1661-74.

197. Lewis LE, Bain JM, Lowes C, Gillespie C, Rudkin FM, Gow NA, et al. Stage specific assessment of Candida albicans phagocytosis by macrophages identifies cell wall composition and morphogenesis as key determinants. PLoS Pathog. 2012;8(3):e1002578.

198. Rudkin FM, Bain JM, Walls C, Lewis LE, Gow NA, Erwig LP. Altered dynamics of Candida albicans phagocytosis by macrophages and PMNs when both phagocyte subsets are present. MBio. 2013;4(6):e00810-13.

199. Cannon GJ, Swanson JA. The macrophage capacity for phagocytosis. J Cell Sci. 1992;101 ( Pt 4):907-13.

200. Acorci-Valério MJ, Bordon-Graciani AP, Dias-Melicio LA, de Assis Golim M, Nakaira-Takahagi E, de Campos Soares AM. Role of TLR2 and TLR4 in human neutrophil functions against Paracoccidioides brasiliensis. Scand J Immunol. 2010;71(2):99-108.

201. Calich VL, Pina A, Felonato M, Bernardino S, Costa TA, Loures FV. Toll-like receptors and fungal infections: the role of TLR2, TLR4 and MyD88 in paracoccidioidomycosis. FEMS Immunol Med Microbiol. 2008;53(1):1-7. 
202. Rossato L, Silvana Dos Santos S, Ferreira LG, Rogério de Almeida S. The impact of the absence of Toll-like receptor-2 during Sporothrix brasiliensis infection. J Med Microbiol. 2019;68(1):87-94.

203. Rossato L, Santos SSD, Ferreira LG, de Almeida SR. The importance of Toll-like receptor 4 during experimental Sporothrix brasiliensis infection. Med Mycol. 2019;57(4):489-95.

204. Chai LY, Kullberg BJ, Vonk AG, Warris A, Cambi A, Latgé JP, et al. Modulation of Toll-like receptor 2 (TLR2) and TLR4 responses by Aspergillus fumigatus. Infect Immun. 2009;77(5):2184-92.

205. Netea MG, Van Der Graaf CA, Vonk AG, Verschueren I, Van Der Meer JW, Kullberg BJ. The role of toll-like receptor (TLR) 2 and TLR4 in the host defense against disseminated candidiasis. J Infect Dis. 2002;185(10):1483-9.

206. Sassá MF, Saturi AE, Souza LF, Ribeiro LC, Sgarbi DB, Carlos IZ. Response of macrophage Tolllike receptor 4 to a Sporothrix schenckii lipid extract during experimental sporotrichosis. Immunology. 2009;128(2):301-9.

207. de C Negrini T, Ferreira LS, Arthur RA, Alegranci P, Placeres MC, Spolidorio LC, et al. Influence of TLR-2 in the immune response in the infection induced by fungus Sporothrix schenckii. Immunol Invest. 2014;43(4):370-90.

208. Villamón E, Gozalbo D, Roig P, O'Connor JE, Fradelizi D, Gil ML. Toll-like receptor-2 is essential in murine defenses against Candida albicans infections. Microbes Infect. 2004;6(1):1-7.

209. Aratani Y, Koyama H, Nyui S, Suzuki K, Kura F, Maeda N. Severe impairment in early host defense against Candida albicans in mice deficient in myeloperoxidase. Infect Immun. 1999;67(4):1828-36.

210. Aratani Y, Kura F, Watanabe H, Akagawa H, Takano Y, Suzuki K, et al. Relative contributions of myeloperoxidase and NADPH-oxidase to the early host defense against pulmonary infections with Candida albicans and Aspergillus fumigatus. Med Mycol. 2002;40(6):557-63.

211. Hole CR, Leopold Wager CM, Mendiola AS, Wozniak KL, Campuzano A, Lin X, et al. Antifungal Activity of Plasmacytoid Dendritic Cells against Cryptococcus neoformans In Vitro Requires Expression of Dectin-3 (CLEC4D) and Reactive Oxygen Species. Infect Immun. 2016;84(9):2493-504.

212. Kajiwara H, Saito M, Ohga S, Uenotsuchi T, Yoshida S. Impaired host defense against Sporothrix schenckii in mice with chronic granulomatous disease. Infect Immun. 2004;72(9):5073-9.

213. Rodrigues DR, Dias-Melicio LA, Calvi SA, Peraçoli MT, Soares AM. Paracoccidioides brasiliensis killing by IFN-gamma, TNF-alpha and GM-CSF activated human neutrophils: role for oxygen metabolites. Med Mycol. 2007;45(1):27-33.

214. Henriet SS, Hermans PW, Verweij PE, Simonetti E, Holland SM, Sugui JA, et al. Human leukocytes kill Aspergillus nidulans by reactive oxygen species-independent mechanisms. Infect Immun. 2011;79(2):767-73.

215. Byrd AS, O'Brien XM, Laforce-Nesbitt SS, Parisi VE, Hirakawa MP, Bliss JM, et al. NETosis in Neonates: Evidence of a Reactive Oxygen Species-Independent Pathway in Response to Fungal Challenge. J Infect Dis. 2016;213(4):634-9.

216. Clark HL, Abbondante S, Minns MS, Greenberg EN, Sun Y, Pearlman E. Protein Deiminase 4 and CR3 Regulate. Front Immunol. 2018;9:1182.

217. Storisteanu DM, Pocock JM, Cowburn AS, Juss JK, Nadesalingam A, Nizet V, et al. Evasion of Neutrophil Extracellular Traps by Respiratory Pathogens. Am J Respir Cell Mol Biol. 2017;56(4):423-31.

218. Rocha JD, Nascimento MT, Decote-Ricardo D, Côrte-Real S, Morrot A, Heise N, et al. Capsular polysaccharides from Cryptococcus neoformans modulate production of neutrophil extracellular traps (NETs) by human neutrophils. Sci Rep. 2015;5:8008.

219. Rosales C. Neutrophil: A Cell with Many Roles in Inflammation or Several Cell Types? Front Physiol. 2018;9:113.

220. Andrews K, Abdelsamed H, Yi AK, Miller MA, Fitzpatrick EA. TLR2 regulates neutrophil recruitment and cytokine production with minor contributions from TLR9 during hypersensitivity pneumonitis. PLoS One. 2013;8(8):e73143.

221. Nance SC, Yi AK, Re FC, Fitzpatrick EA. MyD88 is necessary for neutrophil recruitment in hypersensitivity pneumonitis. J Leukoc Biol. 2008;83(5):1207-17.

222. Sabroe I, Prince LR, Jones EC, Horsburgh MJ, Foster SJ, Vogel SN, et al. Selective roles for Tolllike receptor (TLR)2 and TLR4 in the regulation of neutrophil activation and life span. J Immunol. 2003;170(10):5268-75.

223. Sabroe I, Jones EC, Usher LR, Whyte MK, Dower SK. Toll-like receptor (TLR)2 and TLR4 in human peripheral blood granulocytes: a critical role for monocytes in leukocyte lipopolysaccharide responses. J Immunol. 2002;168(9):4701-10.

224. Pillay J, Tak T, Kamp VM, Koenderman L. Immune suppression by neutrophils and granulocytic myeloid-derived suppressor cells: similarities and differences. Cell Mol Life Sci. 2013;70(20):3813-27.

225. Marks M, Burns T, Abadi M, Seyoum B, Thornton J, Tuomanen E, et al. Influence of neutropenia on the course of serotype 8 pneumococcal pneumonia in mice. Infect Immun. 2007;75(4):1586-97.

226. Arocena AR, Onofrio LI, Pellegrini AV, Carrera Silva AE, Paroli A, Cano RC, et al. Myeloid-derived suppressor cells are key players in the resolution of inflammation during a model of acute infection. Eur $\mathrm{J}$ Immunol. 2014;44(1):184-94. 